\title{
WOMEN'S PERCEPTION OF THEIR FOREST RESOURCES IN ESPIRITU SANTO (VANUATU)
}

\author{
Sarah Brikke \\ Victoria University of Wellington, New Zealand \\ 2008
}

A thesis presented in partial fulfillment of the degree of Masters in Development Studies 


\section{Abstract}

Women's perceptions of their environment in two remote communities (Monxhill and Butmas, in Espiritu Santo, Vanuatu) were explored, as their perception is though to guide their involvement in environmental education. Qualitative insights from participatory fieldwork, using ranking exercise, community resource mapping and perception activities, showed that women of Monxhill see the forest as a place to live, to know and to learn about, to plan for and to take care of. In turn, women of Butmas see it as a resource, which has to be managed in order to provide the communities with food, materials and medicines; however, they also see it as a problem, which has to be solved. Furthermore, this research showed that these women are a key actors in community environmental education. 


\section{Acknowledgments}

I would like to thank first of all Sean Weaver for giving me the amazing opportunity to be able to do my field research in Vanuatu and for believing in me. Thank you also to John Overton for always being so positive and constructive.

To Ralph Regenvanu for approving my research in Vanuatu.

To the staff of Live and Learn Environmental Education for giving me the chance to work in your team and do the field research with you in Santo. Thank you Robbie for all the documentation on environmental education.

To my parents and my brother who always support and help me with my choices and push me to do better always.

To Nathan, who made me love Vanuatu, even more

To the women of Monxhill and Butmas, for participating in this research and for sharing their perceptions with me.

To Bernie, who help me so much the last week, when it was most needed.

And finally to Nature, as humans can learn so much by listening, observing, protecting and conserving it. We have to pay much more attention to the magic and beauty of our environment, by living in a sustainable way and to live in a society based on the well being of our planet. As we are part of our environment it will ultimately benefit us and our future children. 


\section{List of figures and tables}

Figure 1: Location of Vanuatu in the South Pacific .......................................................... 5

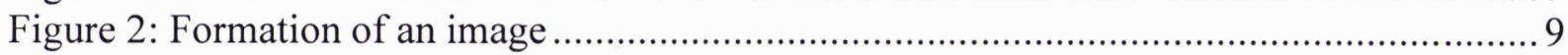

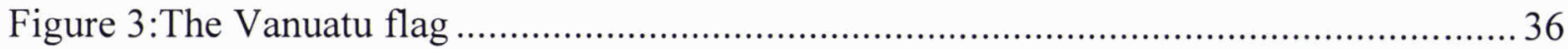

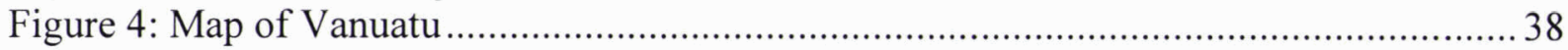

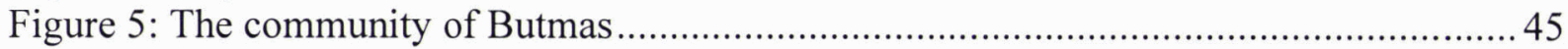

Figure 6: Women and youth group (Butmas) ............................................................... 49

Figure 7: Women's perception of their forest resources in Monxhill.................................6 69

Figure 8 "I see the forest as a place to live" (Monxhill) .................................................. 70

Figure 9: "I see the forest as nature" (Monxhill)......................................................... 70

Figure 10: Women's perception of their forest resources in Butmas .................................. 72

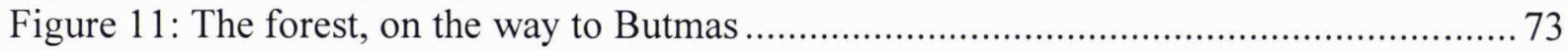

Figure 12: Community resource mapping (Monxhill) .......................................................... 78

Figure 13: Resource mapping on forest conservation (Monxhill) ..................................... 79

Figure 14: Explanation of the 'forest conservation' resource mapping (Monxhill)...............80

Figure 15: Resource mapping on cash-cropping (Monxhill) ........................................... 81

Figure 16: Resource mapping on logging and deforestation (Monxhill) ........................... 82

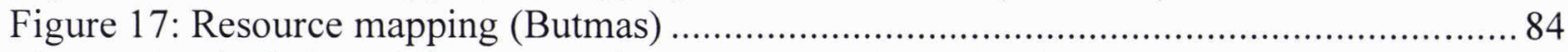

Figure 18: The influential actors on forest conservation (Monxhill) .................................. 86

Figure 19: The influential actors on cash cropping (Monxhill) ...................................... 87

Figure 20: The influential actors on deforestation and logging (Monxhill)........................ 88

Figure 21: Loss of forest area 1990-2000 observed from the satellite data for different islands

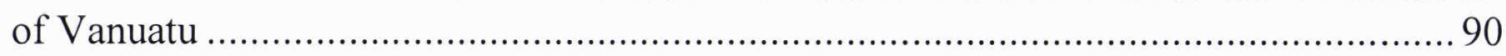

Table 1: The Vanuatu Population Summary ............................................................... 42

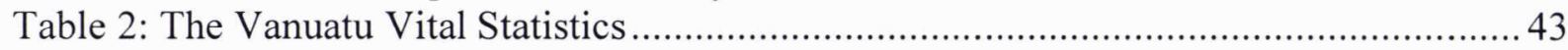

Table 3: List of the needs and concerns of the community (Monxhill)................................56

Table 4: Ranking of the needs (Monxhill) ........................................................................... 59

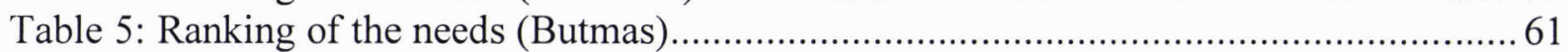

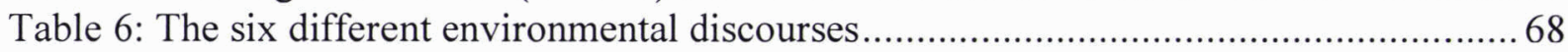

Table 7: Evolution of women's perception of their forest resources (Monxhill).................. 74

Table 8: Evolution of women's perception of their forest resources (Butmas) ..................... 76 


\section{List of abbreviations}

CCBA: Climate, Community and Biodiversity Alliance

CDM: Clean Development Mechanism

CSP: $\quad$ Commission of the South Pacific

ESD: $\quad$ Education for Sustainable Development

FAO: $\quad$ Food and Agriculture Organization

HIV: $\quad$ Human Immunodeficiency Virus

IWDA: International Women's Development Agency

MCA: Millennium Challenge Account

MDG: $\quad$ Millennium Development Goals

MP: $\quad$ Member of Parliament

NGO: Non-Governmental Organization

PNUE: $\quad$ Program of the United Nations for the Environment

RAP: $\quad$ Rapid Assessment Program

SPEC: $\quad$ South Pacific Educational Courses Limited

SPREP: $\quad$ South Pacific regional Environment Program

SWC: $\quad$ Santo Women's Committee

UN: $\quad$ United Nations

UNCED: $\quad$ United Nations Conference on Environment and Development

UNDP: $\quad$ United Nations Development Program

UNESCO: United Nations Educational, Scientific and Cultural Organization

UNFCC: $\quad$ United Nations Convention on Climate Change

UNOPS: $\quad$ United Nations Office for Project Services

VANWODS: Vanuatu Women's Development Development Scheme

VAT: $\quad$ Value Added Tax

VCCP: Vanuatu Caron Credits project 


\section{Tables of contents}

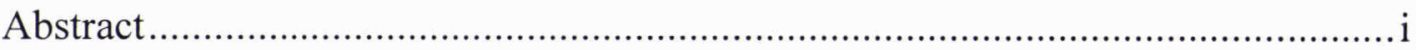

Acknowledgments ..................................................................................... ii

List of figures and tables................................................................................ii

List of abbreviations ................................................................................. iv

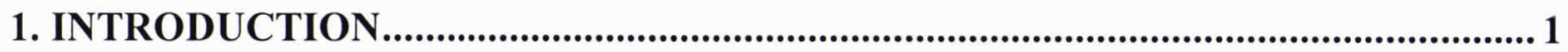

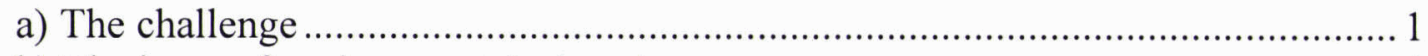

b) The issue of environmental education..................................................... 2

c) An introduction to the concept of perception................................................ 3

d) The case of Live and Learn Environmental Education NGO ............................ 4

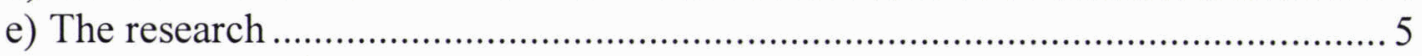

2.CONCEPTUAL CONTEXT ................................................................................ 8

2.1 The concept of 'belonging to an island' ................................................................ 8

2.2 The concept of perception.......................................................................... 8

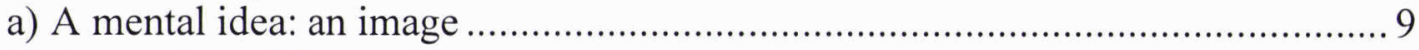

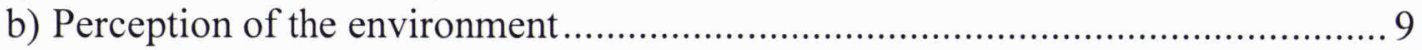

c) Perception on forest conservation ............................................................. 11

2.3 The concept of local community education................................................... 12

2.4 The concept of human/nature relationship ....................................................... 14

a) An introduction to the human/nature relationship.................................... 14

b) An 'emotional' relationship between women \& nature ................................. 15

c) An intimate relationship between people and their natural environment in the

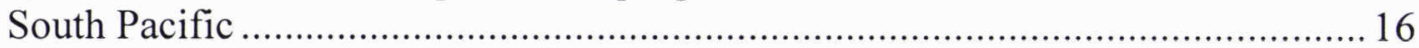

2.5 The concept of development........................................................................ 17

2.6 The concept of sustainable community development .......................................... 18

a) A definition of sustainable development .................................................... 18

b) An introduction to sustainable community education...................................... 18

c) Is the local community the appropriate scale for sustainable development?...... 19

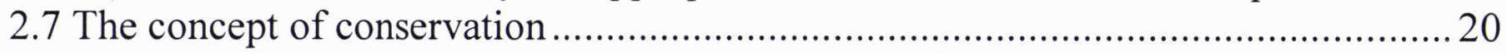

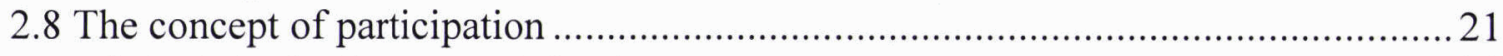

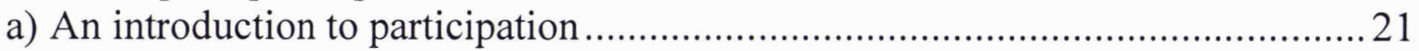

b) Improving citizen / local participation ....................................................... 22

c) Difference between government \& local communities (in decision-making)..... 23

2.9 The concept of empowerment.................................................................... 24

a) Empowerment: a definition.......................................................................... 24

b) Women as environmental educators and factors of change ...........................26

c) The case of Kenya .................................................................................... 27

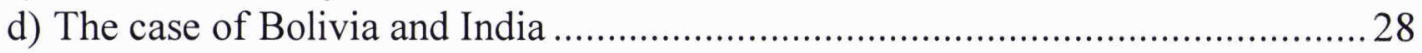

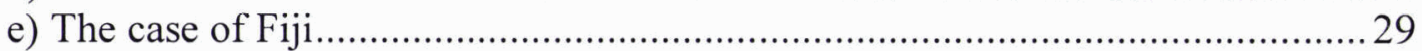

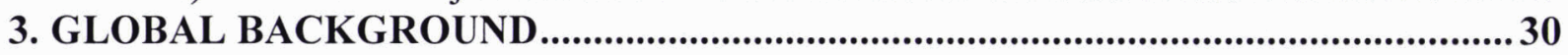

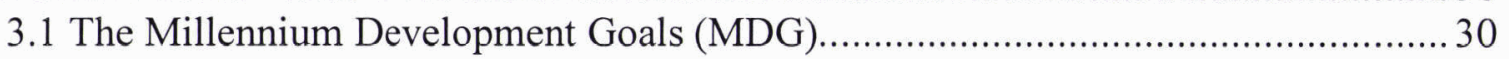

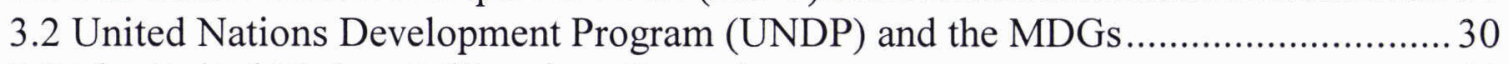

3.3 The United Nations Millennium Campaign........................................................ 31

3.4 Millennium Ecosystem Assessment ..................................................................... 32

3.6 National legislation on protection of forest resources in Vanuatu.......................... 32 


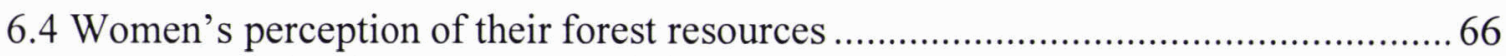

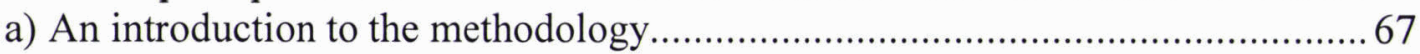

b) Women's perception of their forest resources in Monxhill...................................69

c) Women's perception of their forest resources in Butmas..................................... 71

6.5 The evolution of women's perception of their forest resources.................................73

a) An introduction to the methodology............................................................. 73

b) Evolution of women's perception of their forest resources (Monxhill)...............74

c) Evolution of women's perception of their forest resources (Butmas)...................76

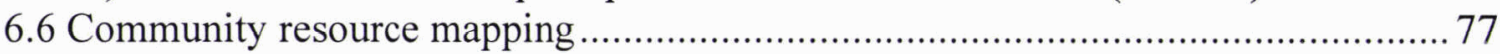

a) An introduction to the methodology ................................................................ 77

b) Resource mapping on forest conservation....................................................... 79

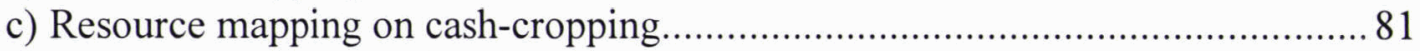

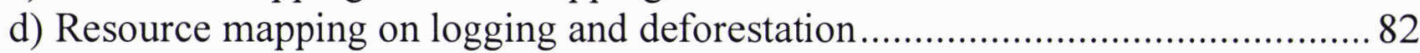

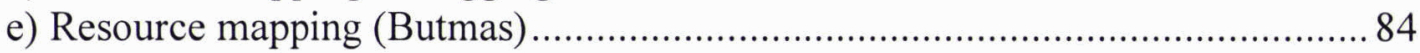

6.7 Women's perception of influential actors on forestry issues................................... 85

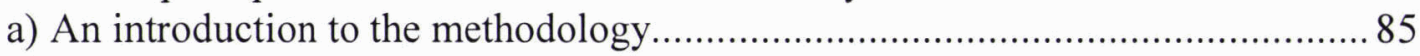

b) Women's perception of influential actors on forest conservation ........................86

c) Women's perception of influential actors on cash-cropping ................................8 87

d) Women's perception of influential actors on deforestation and logging .............8 88

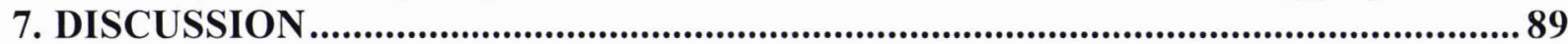

7.1 About women's perceptions of their forest resources (objective 1).........................89

7.2 About women's perceptions of their needs and concerns (objective 2) ................... 90

7.3 About women's perceptions of their role in forestry issues (objective 3) f.............. 92

8. CONCLUSION ...........................................................................................................94

APPENDICES..................................................................................................... 98

Appendix 1: Age and level of education (Monxhill) ……………........................... 98

Appendix 2: Age and level of education (Butmas) …………................................99

Appendix 3: Guidelines for the Facilitator .......................................................99

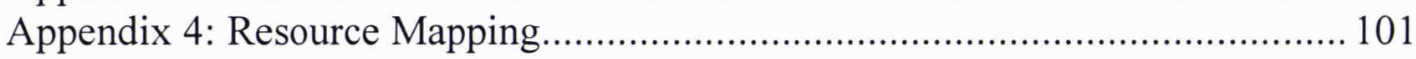

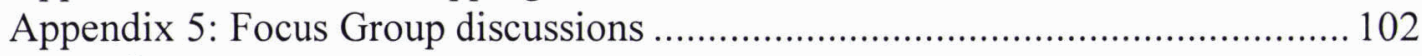

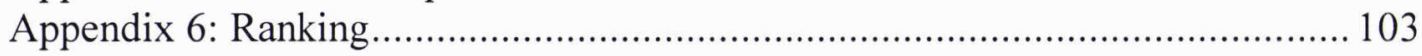

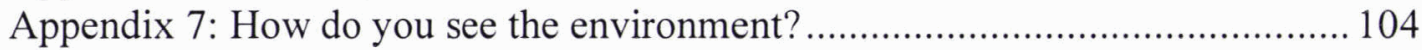

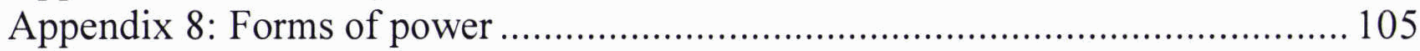

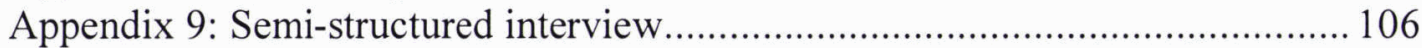

Appendix 10: Poster on the future of the forests in Vanuatu................................ 108

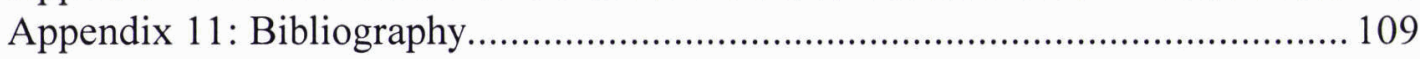




\section{INTRODUCTION}

\section{a) The challenge}

There is an increasing appeal to more consciousness of local populations towards their natural environment. This is a call to change behaviour, to relearn to live and to rediscover the relationships between humans and the environment. We know only too well the destructive environmental repercussions at a world scale, such as climate change, which manifests itself through diverse alarming natural phenomenona such as increasing natural disasters, floods and cyclones. Hopefully, modern society will become more conscious of the exhaustible character of the natural resources of planet Earth. An increasing number of international resolutions and goals on environmental protection and conservation show that these issues are becoming a major and essential challenge for the $21^{\text {st }}$ century (such as the Goal 7 of the Millennium Development Goals, described in chapter 3).

The nations of the South Pacific (through the United Nations General Assembly) unanimously supported the resolution to establish a Decade of Education for Sustainable Development for the period 2005-2014. They did so because education is considered key to sustainable development ... Crucial issues surrounded the question of who had legitimate access to, control over and use of natural resources which is are particularly relevant to the cultural context and current situation in the South Pacific ... It is as much the social and economic relationships between people and institutions, as the relationships between people and natural resource that will facilitate or hamper, progress towards sustainable development (Live \& Learn, 2007).

Finally, we all know that climate change is a major international discussion issue today and is already affecting our lives. The degradation of forests and deforestation is an important factor, contributing $20 \%$ of greenhouse gas emissions that lead to global warming. While forests represent an important component of 
the world's biodiversity, they are today more and more considered an endangered species. The causes of this decline are diverse and entropic, including logging and deforestation.

\section{b) The issue of environmental education}

No one is safe from the many environmental and social problems that threaten our planet and our health, but we are not all endangered equally. In light of this thought, consider today's notion that local cultures must change and adapt to national and international influences, which promote and produce non-sustainable activities and results. For example, a timber company exporting whole logs from local forests to Japan ... may help short-term economic stability but simultaneously it fosters a local community's dependency on outside markets. Through such activities, communities also become increasingly dependent on political forces, over which they have decreasing amounts of control ... Through the concept and practice of local community, people can empower themselves and support one another through decisions that promote a sustainable world as well as increase their quality of life (empowerment through local community) (Maser and Kirk, 1996). This empowerment and promotion of sustainable development can be achieved through environmental education, which links local issues with more global ones. Environmental education is a complex concept. It is locally based and gives the opportunity for the local communities to speak up and be part of sustainable development projects, for the wellbeing of their community and for future generations.

Environmental education today has been challenged to consider the environment in its totality, natural and built, ecological and social, and view itself as a continuous life-long process that takes place both inside and outside the classroom. Clover (1996), stated that "the goals of environmental education are to strengthen environmental awareness through adult environmental education", education being "a long term process to transfer knowledge, but also attitudes and values, both to children and adults". (Jones-Walters, 2000, p.14). "It must assist people to make global and local links, and understand the importance of valuing 
the inter-relatedness of the web of life, and promote concern for all life on the planet" (Tilbury, 1995).

Finally, according to the SPREP (South Pacific Environmental Program, Environmental Education Teachers Manual), "environment refers to all our surroundings - the air we breathe; the soil where we grow our plants in; the fresh water we drink, the sea water we fish and swim in; and the plants and animals that surround us. It also includes all of us, and the people we interact with. The environment is everything around us".

Finally, according to the SPREP (South Pacific Environmental Program, Environmental Education Teachers Manual), "environment refers to all our surroundings - the air we breathe; the soil where we grow our plants in; the fresh water we drink, the sea water we fish and swim in; and the plants and animals that surround us. It also includes all of us, and the people we interact with. The environment is everything around us".

\section{c) An introduction to the concept of perception}

The importance of studying perceptions (in latin, percipere: to perceive) relies on the idea that "action is a function of the image that we make ourselves of the world". (Boulding, 1956). Indeed, each individual creates it's own environment. Before reacting, every society and every human being follows a process of perception.

"Ideally, an assessment of perceptions should entail a thorough and comprehensive exploration and analysis of all stakeholder perceptions, issues and options. Practically, due largely to time constraints, this is often not feasible. Consequently, a Rapid Assessment of Perception was required". (Live \& Learn, 2007).

"As space is not neutral but, to the contrary, is charged with senses, we refer ourselves to spaces that are actually not perceived, that are sometimes imaginary. 
We should take into account these mental processes that show that one space, one situation, one perceived action can be full of significance and values and therefore can open the study of imaginary constructions or imaginary spaces". (Bailly, 1974).

(More information on the concept of 'perception' will be found in chapter 2).

\section{d) The case of Live and Learn Environmental Education NGO}

Live and Learn Environmental Education (with who this research has been done in collaboration) is a non-profit, non-government organization, which promotes greater understanding and action towards human and environmental sustainability through education and dialogue building. Their purpose and aims are to:

- Develop and implement projects and programs for teachers, schools, communities and other target groups in the field of environmental and development education;

- Encourage individual and community attitudes, values and actions that are ethical and environmentally sustainable;

- Share knowledge, skills, learning experiences and resources with others for the benefit of the physical and human environment;

- Promote the integration of environmental, human, cultural and peace concepts in all education projects and programs.

The participatory approach used by Live and Learn Environmental Education in general and for this research in particular, encourages participants to explore and share experiences, ideas and opinions. Before starting to work with communities a Rapid Assessment of Perceptions (RAP) was undertaken, which is a social research task that helps to understand how communities perceive environmental and social challenges, opportunities and constraints. According to the RAP principles, programs should start 'where the communities are at' and a focus should be relevant to community members' lives and needs. 
"The use of participatory methods to enable development of local institutions is an important first step towards changing power relationships". (Shah, 1997, p.94). In order to have sustainable and efficient environmental politics and environmental protection programs, it is indispensable to study and reinforce the involvement of local populations in projects and in environmental education programs.

After having presented the global context in which this research was done, we will now see what this research is specifically about.

\section{e) The research}

This research examined women's perceptions of the forest, in two remote communities (Monxhill and Butmas) of Espiritu Santo, Vanuatu.

\section{Figure 1: Location of Vanuatu in the South Pacific}

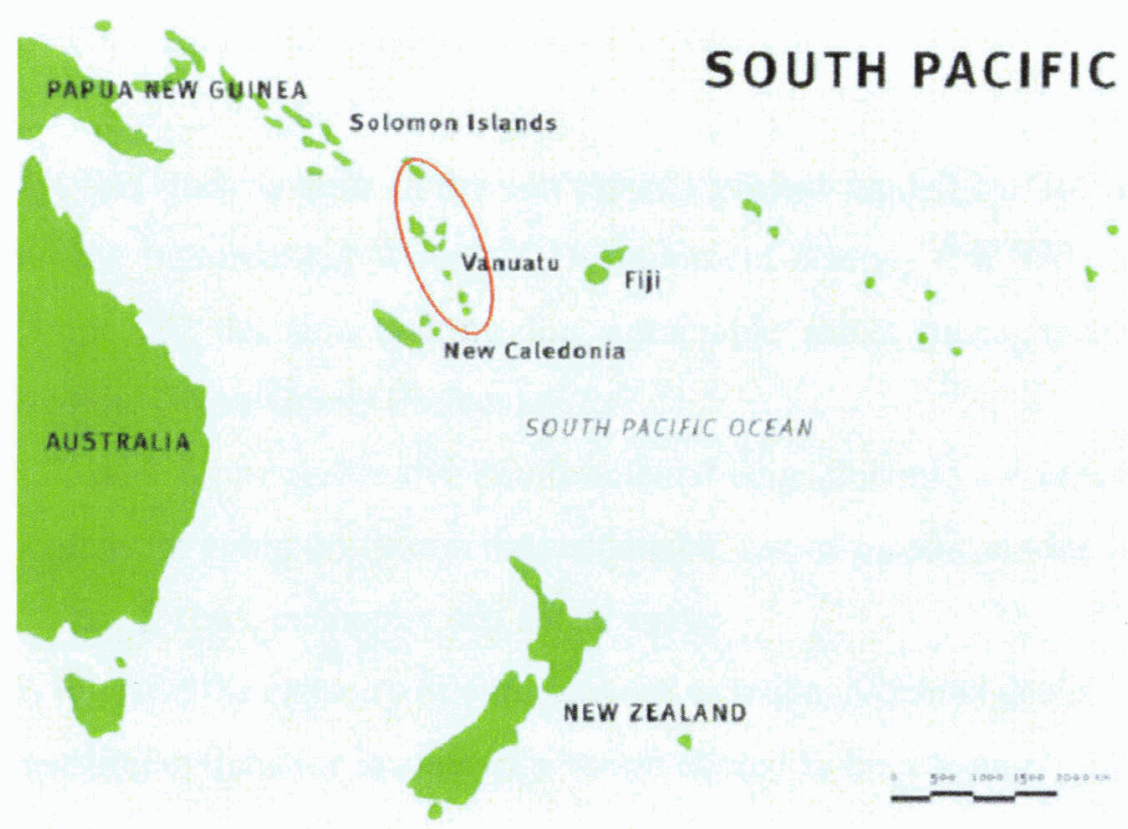

Source: Weaver, 2007

This research has been done in collaboration with this NGO (working as a volunteer on this project, based in Port Vila, Vanuatu), which influenced the choice of the communities (because these communities are particularly affected 
This research has been done in collaboration with this NGO (working as a volunteer on this project, based in Port Vila, Vanuatu), which influenced the choice of the communities (because these communities are particularly affected by deforestation or will be in the future) and the choice of the methodology of this research, such as the use of RAP (Rapid Assessment of Perceptions) and Education for Sustainable Development (ESD).

In addition, this research has focused on women as they play key roles in community life and act as a driving force for community education. If women can learn about protection and conservation of the environment, they can help raise environmental awareness. This research used qualitative and participatory methods, which encouraged participants to explore and share experiences, ideas and opinions.

This project is part of the Vanuatu Carbon Credits Project (VCCP), which is focused on international climate change policy on reducing emissions from deforestation in developing countries. The VCCP is designed to test drive carbon crediting methodologies for reducing forest-based emissions and is a contribution to international policy development currently underway in the United Nations Framework Convention on Climate Change (UNFCCC).

Locally, this study is done in the context of a project funded by Green Grants Project and the International Women's Development Agency (IWDA), which is entitled "Improved decision making for sustainable forest management". The objectives of the Green Grants Project are to:

- (i) Provide a comprehensive environmental education and awareness program for communities on the sustainable use of forests and the links between forests, economic and social issues.

- (ii) Improve the capacity of communities to make informed decisions regarding options for income generation related to the use and development of land and natural resources. 
- (iii) Promote the role of women in active participation in education, decision- making, planning and community action.

- (iv)Assist communities to identify alternative ways to generate income through sustainable land use and forest related enterprises.

- (v) Strengthen community capacity and advocate for sustainable development.

The aim of this research is to understand to what extent an increase in women's participation and empowerment can improve and enhance forest conservation outcomes in Espiritu Santo?

In order to answer this research aim, this thesis will address the following objectives:

1. Identify women's perceptions of the forest in Monxhill and Butmas;

2. Identify women's perceptions of their needs and concerns related to development aspirations in the communities of Monxhill and Butmas; and

3. Identify women's perceptions of their role in forestry issues in Monxhill and Butmas.

In order to understand better in which framework this thesis finds itself, we will discover in the following three chapters: a conceptual context, a global background and a geographical context. The fifth chapter, will explain the methodology used in this research, with its methods to collect data. The sixth chapter will present the results and analysis of this research and the seventh chapter will offer a discussion of the findings. The conclusion of this thesis will be presented in the last chapter. 


\section{CONCEPTUAL CONTEXT}

\subsection{The concept of 'belonging to an island'}

It is Abram Moles (1998), psychologist of the space, who created the concept of 'belonging to an island' (ileite in french). It characterizes the way islanders think.

The islanders, in their closed environment, were able to create their own culture, and their own civilization. They intervene on a miniaturized space, in which each member has to concede each space to every day gestures. Therefore it is by strengthening the links between people that you can give to that space an intense cultural dimension.

As our study is focused on this type of environment, this concept may influence the behaviours and perceptions of the local population.

\subsection{The concept of perception}

The main idea of Kenneth Boulding (1956) on the notion of 'perception' is that "action is a function of the image that we make ourselves of the world". Indeed, each individual creates his or her own environment where he or she lives. It is interesting to "see what is the appropriateness between a real situation and the perceived one. This can be done for example through a sociological investigation in order to see how individuals perceive their space". (Bavoux, 1998). Before engaging an action, every society and every human being follows a process of perception. "It is easier to apprehend what is seen, what is material, than what is thought" (Bailly, 1974).

Moreover, it is important to note that "space isn't neutral for the person in it, but is on the contrary charged with meaning, 'here' is not the same as 'there' and for each human being, space has a value". (Bailly, 1974). This current of geography allows us to refer ourselves to spaces that are actually not perceived, 
that are sometimes imaginary. We should take in account mental processes make that, one space, one situation, one perceived action can be full of significance and values. More specifically, "the Pacific, is first a perception ... This space generates feelings, born of a sensation of immensity ... The perception of the Pacific as a space, in relationship to itself, the earth, human beings, generates logically something imaginary and something symbolic". (Faessel, 1997, pp. 106114).

\section{a) A mental idea: an image}

An image is created by reality that is nourished by information. Then, cultural and psychological factors can modify or amplify the data of the beginning to finally create a new image.

Figure 2: Formation of an image

Cultural factors
Reality $\longrightarrow$ Information $\longrightarrow$
Image
Psychological factors

Indeed, a mental idea can be translated through images or mental maps (Gould, 1974). What does an image depend on? According to the work of Bailly, in Perception des milieux urbains, an image depends on: the individual's psychology, the learnt culture (archetype), the codes of communication (social codes and language), the lived experiences, the socio-economic and professional reflections.

\section{b) Perception of the environment}

The perception of the environment by humans is considered as fundamental, to the point that it constitutes the main departure point of all analyses on the relation between human and the environment. The expression 'perception of the environment' means the awareness and comprehension of human of the environment at a large sense. The word 'perception', is more often assimilated to 
the term 'knowledge'. The expression 'perception of the environment' is applied to the sensorial perception as well as to the knowledge. The roles of the researches concerning the perception on the environment in relation between human and the biosphere can be resumed through the five following objectives:

- Contribute to a more rational use of the biosphere resources;

- Increase the comprehension of the different perceptions of the environment;

- Encourage the local participation to development and planning;

- Help to preserve and to register the perceptions and systems of knowledge of the environment; and

- Act as an educational instrument and an agent of evolution.

The environment is perceived through different ways depending on the communities, the individuals and their life experience. The ideas and messages of the world that humans hold in their heads are building blocks of communication. But these ideas and images are based on very incomplete knowledge. "We know some facts, and our imagination fills in (constructs) the rest. How we fill this in depends a lot on our individual values, standards, convictions, interests and knowledge ... Unfortunately, we don't know which part of our idea is based on fact, and which parts we 'constructed' ourselves (Jones-Walters, 2000, p.10). Ultimately, the meaning of a message is not determined by the words, symbols or gestures used, but by the interpretation it gets in the heads of people". (JonesWalters, 2000, p.12).

Moreover, the struggle against the degradation of the environment and the restoration of its resources have to support themselves on multiple forms of comprehension and then on actions. For example, the Regional Program for Oceania on the Environment launched in 1980 and sponsored by the Commission of the South Pacific, the Program of the United Nations for the Environment (UNEP), the ex-secretary of the South Pacific Forum (SPEC) and the Economic and Social Commission of the United Nations for the Pacific, want to cover the totality of the environmental problems at a regional scale. Often, those 
international or national programs are confronted with the local sense of identity, with the different perceptions of the environment, the financial economical interests, the poor knowledge on the functioning of space, to the incompatibility between cultural, administrative and natural areas, and finally to the absence of taking in account the populations and their needs.

"We notice a success of the NGOs or associations working for the protection of the environment who, by their systematic actions on population awareness, are often the only ones with the field scientists to send back to the decision makers, several aspects of natural and human constraints and the bad effects of this or that management or project". (Jost, 1994).

\section{c) Perception on forest conservation}

The word 'forest' can mean different things for different people. Although they all associate the word forest with a tree-covered area, the real 'meaning' they give to it depends on their values, standards, convictions, interests and knowledge. "To someone who is interested in new age philosophy it can be a sacred place for meditation; and for the owner of a timber company it can be a profitable source for wood to be exploited and for ecologists it can be a complex ecosystem to be studied". (Jones-Walters, 2000, p.11). "When the message does not take into account nor respects the way others see the world, people will ask themselves why they should care, or why they should do what the authorities or other agents ask them to do. Information has a much better chance of being accepted and used if it relates directly to the needs of the target audience, and can be applied by them in some way in their everyday lives". (Jones-Walters, 2000, p.15).

Often we communicate because we want our communication partner to change his or her behaviour. This is not a one-step process. Just sending a message is not enough. The message has to be heard, understood and agreed to, before any change in behaviour can occur. Even then it is not certain that the 
change will be permanent. The following list is the evolution of the communication process:

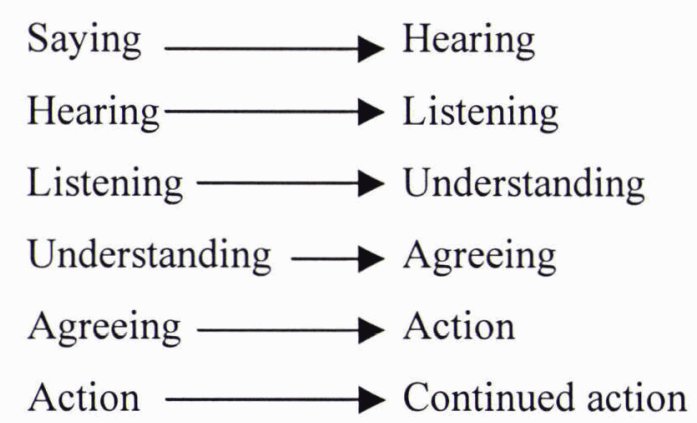

(Jones-Walters, 2000, p.16).

"A final problem in communicating about nature conservation is the fact that nature conservationists often have a 'negative message'. Nature conservationists spend a lot of time telling other people what they are allowed to do ... In fact, nature conservation is often seen as a nuisance or a barrier to progress". (JonesWalters, 2000, p.25). "A conservation plan in itself can sometimes be seen as a form of criticism. If a conservation organization develops a management plan for a forest, the owner can interpret this as a sign of distrust: "Are you saying that I don't take good care of my own forest?".(Jones-Walters, 2000, p.25). Indeed, it is important to know the needs and concerns of the community with whom we work. The message has to be clear, and the community has to feel involved and that its ideas are taken into account (the so-called 'bottom-up' rather than 'top-down' approach) in local community education.

\subsection{The concept of local community education}

"Insofar as I am a conscious presence in the world, I cannot hope
to escape my ethical responsibility for my actions in the world".
(Freire,1972)

"Paulo Freire was one of the most inspirational thinkers on education and community mobilization in the twentieth century. As the education Minister of Brazil, he fiercely promoted the right and responsibility of all education to be rooted in environmental, cultural, social, economic and political realities whilst at 
the same time being educational and free of political agendas". (Live \& Learn Annual Report, 2006). His thoughts inspired educators and community developers across the world.

"A local human community is a group of people with similar interests living under and exerting some influence over the same government in a shared locality. They have a common attachment to their place of residence, where they have some degree of local autonomy. People in a community share social interactions with one another and with organizations, beyond government and through such participation are able to satisfy the full range of their daily requirements within the local area. The community also interacts with the larger society, both in creating change and in reacting to it". (Maser and Kirk, 1996). Moreover, "a community ... focuses on increasing socialization, mutual aid, economic activity, social participation and control, which in turn increases the social, educational, and cultural stability of a community." (Maser and Kirk, 1996). A local community is a complete organization where it is easy to understand better the needs and concerns of the local people. It also tries to resolve problems and to work as a team in decision-making. Thanks to community education, the community will be more aware of what is happening inside and outside the community. Local community education "focuses primarily upon the community, utilizing all existing resources (physical, financial and human) to provide learning experiences and address problems" (Clark, 1984). Education is a fundamental factor for a community. To be educated is a right. According to Clark (1984), "community education is a concept which is rooted in the most fundamental principles of democracy: availability of education to all community members throughout their lives; systematic involvement of citizens in educational decisionmaking and community problem-solving; full utilization of existing community resources (physical, financial and human) to provide meaningful experiences; sharing of resources (among educational institutions, human services agencies, and the community's private sectors)". 


\subsection{The concept of human/nature relationship}

\section{a) An introduction to the human/nature relationship}

When I was growing up almost everybody appreciated nature.
Trees could not be uprooted without a reason; today, you are
lucky if you find enough wood to boil water for your tea. We
have lost birds, the flowers, and the trees ... When I touch the
soil I am looking for answers ... maybe I can find answers by
feeling the texture of the soil or gazing at the sun rise ... I am not
sure ... we have lost the relationships ...
(Wane, 2002, p.140)

According to Wane and Chandler (2002), "African women emphasized the importance of harmony and reverence, not only for herself and her family, but also for what surrounds her. She felt that creating reciprocity helps to maintain a balance between life-sustenance and loss. ... The interview captures the intricate relationships in the universe and the complexity of the dimension of balance restoration". In fact, the message of this Embu woman in Kenya, can be related to the idea that environmental education has a deep purpose, which is, to develop (through different activities) and to strengthen, the relationship that bonds human beings with nature. It "must try to understand better the human/earth relations and what makes people love or hate, fear or embrace the rest of nature" (Clover, 1997). Indeed, according to Clover, Follen and Hall (1998, p.22),“environmental adult education is about the fundamental transformation of human/earth relations."

Moreover, "the traditional role of environmental education has been to teach 'about' the environment ... and about responsibilities and opportunities for acting in an environmentally responsible manner". (Dovers, 1999). By learning the importance of each living creature and understanding the consequences of human impacts, humans can learn how to become more related and more respectful towards nature. To take an example from the Pacific, according to SPREP 
(1997), "the habitats, health and happiness of Pacific islander's are dependent upon the environment and its conservation". That is to say that most of Pacific islanders life is threatened by environmental conditions. If we do not learn to live peacefully and respectfully with nature, more and more natural disasters will extinguish certain communities on this world. "The community as a whole interacts with the local environment, molding the landscape within which it rests and is in turn molded by it" (Mase and Kirk, 1996). Indeed, environmental education teaches the community how to be more responsible and active in the decision-making concerning their environment. It also encourages "people to better understand their own communities and lifestyles by using the community as a site of learning" (Clover, Follen and Hall, 1998, p.22.). According to SPREP, "the purpose of environmental education is to teach people about their environment and its resources, and to explain why good management and conservation practices are necessary (SPREP, 1997).

\section{b) An 'emotional' relationship between women \& nature}

"Let's sit down here ... Let's us have no blankets to sit on, but
feel the ground with our bodies, the earth, the yielding shrubs.
Listen to the air. You can hear it, feel it, smell it, taste it ... we sit
together, don't touch, but something is there; we feel it between
us, as a presence. A good way to start thinking about nature is to
talk about it. Rather talk to it, talk to the rivers, to the lakes, to the
winds as to our relatives". (Abram, 1996, p.225).

According to Wane and Chandler (2002, p.88) "the universe is around us, below us and above us, and is part of who we are ... Embu women were known ... as women who talked to themselves at all times ... They talked at the rising and setting sun; they talked to plants, to the cows, to the sky, and to all living elements". 
In our modern societies, people who would do that would be judged as eccentric, whereas in country such as Kenya, where people understand that there is an upper level of connection with natural and all living creatures, women connect with energies and their ancestors by talking to their environment. In those conditions, spirituality is common every day.

Unfortunately, "these women's knowledge, connection or 'ways of thinking' may not be considered scientific by Western scientific standards, partly because of the links to intuition or to the supernatural". (Wane, $\mathrm{N}$ and Chandler, D.J., 2002, p.94). This idea of the presence of an 'emotional' relationship with nature is encouraged by environmental education whose aim is to seek for a re-connection "in a more sensory, spiritual and emotional way with the rest of nature in both urban and rural environments, using the rest of nature as a teacher/educator" (Clover, Follen and Hall, 1998, p.22). Environmental education encourages "the use of all senses in relating to the rest of nature" (Clover, Follen and Hall, 1998, p.9).

Moreover, "when foreign or foreign-trained experts introduce environmental or development projects, indigenous women's knowledge in relation to farming or the local ecology remain largely excluded and ignored."(Njiro, 1999). "Many environmental educators have developed an educational practice that has the ability to help people connect with the rest of nature through sensory perception and emotion, which arises from the idea that understanding can flow from feelings and intuitions, as much as from scientific knowledge". (Clover, 1996).

\section{c) An intimate relationship between people and their natural environment in the}

\section{South Pacific}

"Traditionally, an intimate relationship exists between people and their natural environment in the South Pacific. The land and the sea are not only vital for subsistence and exchange, but also form the basis for kinship systems and 
spiritual values ... While immediate survival requirements took precedence over any longer term notions of conservation, traditional practices such as genderspecific food taboos, temporary bans on resource exploitation and the use of lowimpact techniques, ensured ecological sustainability by limiting the degree to which any one resource was exploited". (Fien and Passingham, 2002, p.65). This traditional way of controlling the number of living species by not intruding nature, is called "rahui" in French Polynesia. Traditional values in the Pacific still remain strong in some areas, but unfortunately traditional knowledge and ways of life are coming under threat, due to the exposition and influence of the western world and globalization.

In Vanuatu, the relationship between humans and the land is very strong and ancestral. "Land to Ni-Vanuatu is what a mother is to a boy. It is with land that he defines his identity and it is with land that he maintains his spiritual strength. NiVanuatu do allow others the use of their land, but they always retain the right of ownership". (Van Trease, 1987)

\subsection{The concept of development}

"Development can be understood as a process of change that affects people's lives. It may involve an improvement in the quality of life as perceived by the people undergoing change".

(http://en.wikipedia.org/wiki/Development_geography).

Whereas, "economic development is the development of economic wealth of countries or regions, to enhance the wellbeing of their inhabitants". (http://en.wikipedia.org/wiki/Economic_development).

Unfortunately, sometimes during the process of development, some resources get destroyed. That is why we need to ensure that development is undertaken carefully, and includes careful management and conservation of resources. Only then can development improve our lives. 


\subsection{The concept of sustainable community development}

\section{a) A definition of sustainable development}

"Sustainable development was defined by the Brundttland Commission (Brundtland Commission, 1997) in the following way: development that meets the needs of the present without compromising the ability of future generations to meet their own needs". (Deai \& Potter, 2002, p.275).

\section{b) An introduction to sustainable community education}

"Sustainability means that development programs must, to the extent possible, integrate the local people's requirements, desires, motivations, and identity in relation to the surrounding landscape ... In turn, a community's world view defines its collective values, which in turn determines how it treats its surrounding landscape." (Maser and Kirk, 1996). Indeed, according to the way a community perceives its environment, the community will have a particular behaviour towards nature. If they perceive the environment as something which needs to be taken care of and is essential for their well being then, they will make sure to protect and conserve the environment.

On the other hand, if the community perceives the environment as something with which they could earn money for example by selling the timber, then, they will destroy their environment and will not leave many resources for future generations. It is therefore important to know which are the perceptions, beliefs, concerns and needs of the communities, in order to have a better understanding of their behaviours and decisions according to the environment and development. But unfortunately, the voices of the community members are rarely listened to nor taken into account. Ameyaw (1992, p.267) acknowledges the fact that "people at the local level, those most directly involved with or responsible for environment and development initiatives, are frequently ignored ... Yet, the local, not the national communities, are the major vehicles through which sustainable development decisions and projects, human resources inputs, techniques, values and ideas are, or will have to be implemented". Moreover, "people want the most 
effective, productive, and rewarding way of working together to achieve a common end" (Maser and Kirk, 1996).

Finally, sustainable development is based on local and small-scale initiatives. It emphasizes on meeting basic needs first and is focused on community selfreliance rather than on outside dependence. "A service is sustainable when it functions and when it is being used: when it continues over a prolonged period of time (which goes beyond the life cycle of the (water equipment), when it's management is institutionalized ... and when it does not affect the environment." (Brikke, 2000).

\section{c) Is the local community the appropriate scale for sustainable development?}

Local community development is a "process of organization, facilitation, and action that allows people to help create a community in which they want to live. It is a process in which the ideals of sustainable development can be implemented by both allowing and encouraging people to act as catalysts for sustainable change". (Maser and Kirk, 1996, p.169).

The community is the main actor who decides what it wants to do. Environmental education does not help only by knowing better what the needs and concerns of the communities are, but also and not least, it helps to understand the way in which communities can improve their lives and be a factor of change. Indeed, "environmental adult education is a key tool to help people to work locally to improve their lives, to understand the global impacts and implications of what they do, and to work together for change" (Clover, 1997). Moreover, for "people to become environmentally literate, requires that we stimulate knowledge, understanding, awareness, commitment, skills and then action" (Ibikunle-Johnson, 1987).

Local community sustainable development is a fundamental process to give voice to the people and allows each member to participate and to be an actor of change. Unfortunately, this is not always the case in development projects for 
example who prefer acting using a 'top-down' rather than a 'bottom-up' approach. By using the 'bottom-up' approach, projects which are implemented in this type of environment, will be certainly sustainable and will be well taken care of, in the long term, by the community, as it responds directly to their needs. Maser and Kirk's study, Local Community Development (cited in Maser, Resolving Environmental Conflict: Towards Sustainable Community Development, 1996), states that "Local community governments, as opposed to county, state, or national governments, have both a greater degree of understanding and the interaction necessary to amend local problems ... They are therefore better able to implement and adjust to aspects of sustainability in the social/environmental arena". Moreover, according to Schumacher (Schumacher, 1999), in Small is beautiful, being small (at a community level for example) has an "advantage of smallness", as it allows community members to identify their problems, to suggest solutions and to use local resources.

\subsection{The concept of conservation}

Conservation and training of conservationists are not activities which are opposed to development and to change. Rather, they are activities, which work together with development to make sure that there will be enough resources and healthy environment for use by future generations. A good developer must be also a good conservationist. He must try to fully understand the costs of development, including the benefits that may be obtained by using the environment in a sound way.

Ecologists are scientists who study the way in which living organisms, including human beings, interact with each other and with their surroundings. Moreover, the word 'eco' comes from the Greek word 'home'. Ecologists study the 'home' systems or environment of living things.

In the Pacific islands, it is particularly important for an ecologist to understand the valuable uses that people make of their ecosystems, particularly their land, sea and forests. With the help of ecologists and conservationists, we can predict the effects that the activities of human beings and their development projects will have on the environment, for example, what the effects of logging for export of 
timber, will have on the soil, water resources and the climate. We depend on the environment, but often in the way we mis-use it, we unfortunately can have a negative impact.

\subsection{The concept of participation}

\section{a) An introduction to participation}

For the Oxford English Dictionary, participation is "the action or fact of partaking, having or forming part of" (Rahnema, 1992, p.116). "First though, communities need to engage all parts of the community in the planning process, and to stimulate a desire and willingness to participate". (Rogers and Ryan, 2001). "To accomplish participative development, leaders must create and maintain emotionally safe environments within which people can develop quality relationships with one another (Maser and Kirk, 1996)".

A Chinese proverb: "I hear and I forget; I see and I remember; I do and I understand", explains well the aim of participation. It is by doing, making, acting, participating that we learn and understand things.

According to Clover, Follen and Hall (1998, p.22), environmental education is: "being experiential, inter-active, participatory and fun ... and is using people's own potential to solve problems and bring about social and political change". Environmental education is a concept that values the notion of 'participative development' as it is the most sustainable way for a community to act. "When learning, people remember $20 \%$ of what they hear, $40 \%$ of what they hear and see, and $80 \%$ of what they discover by themselves. This calls for a change in the way of teaching, from a typical lecturing to a more participatory approach ... By being involved in this process, both individuals and the group gain a new awareness of their potential, develop greater self-confidence, and see new possibilities." (Brikke, 2000, p.6). Community workers, officers, facilitate the participation of people in this process. They enable connections to be made between communities and with the development of wider policies and programs. 
To conclude, "environmental education for adults has to ... begin from where people are, in their homes and communities. The workshops are participatory and experiential and incorporate diverse and creative activities such as presentations, brainstorming and small group discussions, role-playing, storytelling, drama, music and field visits." (Clover, 1996).

A good example of community theatre is the 'Pacific Star', which is a community theatre as environmental learning in Vanuatu. "This way of sharing information has a strong pedagogical power, as the spectators can identify themselves with the characters of the play. Being both oral and highly visual, community theatre can make ideas and information available to a wide range of people, including the poorest, the most disadvantaged and the most remote ... As a result, community theatre has the potential to be an effective medium for community learning." (Fien and Passingham, 2002, p.66).

\section{b) Improving citizen / local participation}

Participative development aims to improve citizen and local participation. Indeed, if all the community members are involved in resolving environmental conflicts, this could lead towards a sustainable community development. The more citizens participate, the stronger the community will be. "Participative development is one of the greatest privileges in our democracy and one of our greatest responsibilities ... Participative development must begin with a firm belief in the potential of people ... A vitally important component of sustainable community development is local citizen participation in planning, implementing, and monitoring programs, policies and projects." (Maser and Kirk, 1996).

"If everybody works together as a team, then the sense of responsibility will be shared amongst all of the persons involved. Therefore, the art of working together lies in how people deal with change, how they deal with conflict, and how they reach potential." (Maser and Kirk, 1996). "Facilitation works best when certain values are accepted ... such as democracy (each person has the 
opportunity to participate without prejudice), and responsibility (each person is responsible for his/her experiences and behaviors." (Brikke, 2000).

A prerequisite for working towards sustainable outcomes from decisionmaking and development action is to increase people's awareness of their connection to one another within their local community; their communal connection to their immediate environment and its surrounding landscape; and their community's place within the larger regional, state, national, and global communities (Maser and Kirk, 1996).

\section{c) Difference between government \& local communities (in decision-making)}

Louise Fortmann (1996) says that "in development circles - including the arena of women and environment - the notion of who is an expert and whose expertise counts is often shaped by the unsavory forces of elitism, racism, and neocolonialism".

Unfortunately indigenous knowledge is rarely taken in account, although, "the accumulated experiences enable indigenous people from a particular community to claim expertise" (Wane and Chandler, 2002, p.93). Moreover, "sustainable community development is based on the assumption that the best ideas usually come from the people, not the policy makers" (Maser and Kirk, 1996). Neither government authorities nor NGOs can successfully protect nature on their own. "They depend on the co-operation of a wide group of people and organizations whose actions directly or indirectly affect nature: land owners, visitors to protected areas, hunters, farmers, government departments, local and regional authorities, foresters, tourism operators, politicians and so forth ... This means that good communication will be of vital importance". (Jones-Walters, 2000, p.13). The Rio Agreement in 1992 stated that local authorities should take advantage of their position as "the level of government closest to the people" and promote sustainable development by "educating, mobilizing and responding to the public" (UNCED, 1992, p.28). 
An "effective participation might be ... a sustained conversation between technical officers, local politicians and local people, about the problems of a locality (social, economic, political, environmental), about what can be done to solve them, how it can be done and who should do it" (Forbes, 1987, p.133)

A number of major international aid organizations agreed that development projects had often floundered because local people were left out. It was found that, whenever people were locally involved, and actively participating, in the projects, much more was achieved with much less, even in sheer financial terms (Rahnema, 1992, p.117). Therefore, "people are no longer waiting for handouts from governments. They no longer assume that technology and science will fix environmental problems. Likewise, governments are beginning to understand that more than rules and regulations or dollars are needed to resolve environmental problems: without citizen participation, little can be achieved" (Clover, 1997).

According to Maser and Kirk (1996), in Local Community Development, given their own tools, local communities are more effective in defining and meeting their own needs, at lower costs, than are any governments or private service providers, and so begins a populist movement.

\subsection{The concept of empowerment}

When several small streams come together they become a big stream (Kamla Bhasin, 1992, p.35).

\section{a) Empowerment: a definition}

"Empowerment is more than participation in decision-making; it must also include the processes that lead people to perceive themselves as able and entitled to make decisions". (Rowlands, 1997). "Empowerment is not just a gender issue, but a development issue affecting women and men ... (Jo Rawlands) is convinced that the key to empowerment lies in mobilizing marginalized people, especially women. She cautious, however, 
that empowerment is a process rather than an end product, neither easily defined nor measured". (Parpat, 2002). "Empowerment refers to increasing the spiritual, political, social or economic strength of individuals and communities. It often involves the empowered developing confidence in their own capacities". (http://en.wikipedia.org/wiki/Empowerment). For Batliwala (1994, p.130), empowerment is "the process of challenging existing power relations, and of gaining greater control over the source of power" and it acknowledges the need to improve the lives of grassroots women". (Desai \& Potter, 2002).

Moreover, "empowerment $\ldots$ addresses people's perceived capacity to influence decisions that affect their lives through active participation in and hence improvement of the democratic process. Central to the notion of empowerment is people's willingness to accept responsibility for their own behaviour." (Maser and Kirk, 1996).

Community development seeks to empower individuals and groups of people by providing these groups with the skills they need to effect change in their own communities. It is also a "mechanism through which people empower themselves by increasing their ability to control their own lives in order to create a more fulfilling existence through mutual efforts to resolve shared problems ... with collective action people can successfully resolve their issues as well as organize and implement change. It thus promotes a sense of accomplishment and belonging through shared learning and service." (Maser and Kirk, 1996).

One of the other objectives of empowerment is "empowering people to see themselves as agents of change" (Clover, Follen and Hall, 1998, p.22). "When A considers it is essential for B to be empowered, A assumes not only that B has no power- or does not have the right kind of power- but also that $\mathrm{A}$ has the secret formula of a power to which B has to be initiated ... The crux of the matter is that the populations actually subjected to this fear-power are not at all powerless." (Rahnema, 1992, p.123). "In indigenous societies, knowledge is collectively and communally owned, not monopolized or standardized by individuals" (Wane, $\mathrm{N}$ 
and Chandler, D.J., 2002, p.93). There is a lack of emphasis of indigenous knowledge in our educational system. It is unfortunate because "schools treat indigenous communities as if they have no knowledge." (Batibo, 2001, p.320). "Oppressed minorities (whether ethic or sexual) and oppressed majorities (such as women, or black people in South Africa) will be unable to effect any substantial change in their individual lives without collective action." (Brookfield, 1987, p.63).

\section{b) Women as environmental educators and factors of change}

"The problem that has no name" is the phrase used by Betty Friedman (1963) in The Feminine Mystique to describe the sense of alienation and uneasiness felt by women who were experiencing profound discrepancies between the fulfillment they expected from playing the role of dutiful housewife, subservient spouse, and dedicated mother, and the stagnating and constricting reality of their lives (Brookfield, 1987, p.55).

The women's movement offers a good illustration of how perceiving the connection between personal troubles and social forces leads to social as well as individual change (Brookfield, 1987, p.59). Throughout history, it has invariably been women who have blown the whistle on the negative impacts of environmental degradation and human manipulation of the environment (Seager, 1993; Mies \& Shiva, 1993; Wyman, 1999). Eco-feminism, as a theory, emerged in the 1970s with an increasing consciousness of the connection between women and nature (Wane, N and Chandler, D.J., 2002, p.87). Eco-feminists, such as Susan Griffin (1978) and Mary Daly (1978), claim a spiritual union between women's cultures and knowledge of nature. (Wane, N and Chandler, D.J., 2002, p.88). Feminist adult education is also a process of "concientizacion", a term developed by Paulo Freire to signify the process in which people are not recipients, but knowing subjects who achieve a deeper awareness of the sociocultural reality that shapes their lives and their own ability to transform their reality. Feminist adult educators seek to transform women by including their daily reality and experiences into the process of learning (Clover, D.E.;Follen,S. and 
Hall,B., 1998, p.16). Women are often the first environmental educators. In their homes and communities they pass along a unique understanding of the natural processes, which take place around them (Clover, D.E.;Follen,S. and Hall,B., 1998, p.18).

Although this knowledge is not often classified as 'scientific' and therefore, does not appear in textbooks, it is of profound importance to the survival of this planet (Clover, 2002, p.317). Through their education practices, women have become active agents of change in society. The teaching methodologies and practices they use to foster environmental action are inclusive and sensitive to gender. Women's education methodologies aim at empowering those with little or no power and enabling people to see that they do have the power to work towards social and ecological change (Ba N'Diaye, 1993; Dankelman and Davidson, 1988; Rodda, 1991).

Environmental education must learn and draw from the knowledge of indigenous people, those who are most often closest to the land (Clover, 1996). Several examples from around the world will be presented here below in order to understand better and to illustrate the empowerment of women in those countries. There is a need for us to borrow from African women's philosophy in order to create balance in our world (Wane, $\mathrm{N}$ and Chandler, D.J., 2002, p.96)

\section{c) The case of Kenya}

"Look around you ... where are the thick forests that we used to have? ... These days, people have cultivated up to the top of the mountain ... human's greed has chased the spirits of our ancestors that used to live here ... your generation needs to ... slow down the pace of destruction.

(Wane, 2000, p66, interview with Cucu, an Embu woman from rural Kenya in 1994). 
African people, especially women, tended to hold nature as sacred within a relationship of respect and reverence, contrary to the Western scientific urge to control and dominate nature (Wane and Chandler, 2002, p.92). According to Wane and Chandler, (2002, p.87), in African women, cultural knowledge, and environmental education with a focus on Kenya's indigenous women, women are connected to the land and the environment. The women have a vast knowledge of the environment, which we argue could be incorporated in our teaching to contribute to environmental education ... The cosmology or belief system of the ancient people of Africa has a relevance to how many African communities, and especially Embru rural women, understand and conceptualize ecosystems, environmental change, and conservation today. Most women emphasized the first cosmological principle among Embru people: the need to care for every form of life, human beings, plants, animals, including invisible plants and animals of the universe ... interdependence between the various components of the earth, including the geological, atmospheric, and spiritual systems. These Embru women knew, and have known, that disturbing one biospherical part would also affect other parts (Wane and Chandler, 2002, p.91). Women in particular were and are held as custodians of the land. This knowledge is passed on to the next generation through stories, riddles, proverbs, and folklore (Kenyatta, 1965). As a result, throughout the ages, African children were taught to respect the earth (Wane and Chandler, 2002, p.91).

\section{d) The case of Bolivia and India}

According to Lechte, (1993), in Women as Educators for Primary Environmental Care, in Bolivia, women use songs, popular theatre and video and other media are used as educational tools for working in communities with adults around environmental issues (Lechte, 1993). In India, women hug trees to stop them from being felled, and throw themselves in front of bulldozers to prevent the clearing of their land for industrial use (Shiva, 1989). 


\section{e) The case of Fiji}

Women living in the interior of larger Pacific Islands like Fiji depend on biological resources for health-care, medicines, food, fuel and craft materials for their families and communities' subsistence, and cultural and economic needs. In light of this, an environmental education community workshop was organized in Fiji to take women into the rainforests to explore their relationships with the ecosystem through experiential exercises. For five days, women lived with Nadovu villagers, experiencing their dependence on the productive rainforest through role-playing, identifying uses of trees and plants, hikes, songs and theatre performances. The workshop ended with a visit to the local sawmill and to logging operations, where the women observed oil leaks, soil erosion and sawdust contamination. Through these activities, women were able to increase their awareness of the value and fragility of biological diversity and see the impact of human activity on the natural world around them. The women emerged from the forest "with a firm commitment to environmental management and to protecting and sustaining resources" (Pachamama, 1995). According to SPREP (1997), in Environmental Education teachers' manual - Environmental Education issues in the Pacific, without proper management of the environment and careful conservation, there will be no future for the small, fragile environment and the people of the Pacific islands.

After having been introduced to the conceptual context of this research, we will now see the global context with which this research is related to. 


\section{GLOBAL BACKGROUND}

\subsection{The Millennium Development Goals (MDG)}

This research has a strong link with the MDG's goal 7. Indeed, Goal number 7 of the MDGs aims to "ensure environmental sustainability, by integrating the principles of sustainable development into country policies and programs; reverse loss of environmental resources by reducing biodiversity loss (achieving, by 2010, a significant reduction in the rate of loss) and by reducing by half the proportion of people without sustainable access to safe drinking water." (http://www.undp.org/mdg).

\subsection{United Nations Development Program (UNDP) and the MDGs}

To help mobilize the potentially significant benefits of carbon finance for the developing world, UNDP has established the MDG Carbon Facility, which is an innovative mechanism for the development and commercialization of emission reduction projects.

Climate change has emerged as one of the most important issues facing the global community in the 21 st century. It will pose a serious threat to development and poverty reduction, and the effects will be felt most strongly by the poorest people in the least developed countries, who rely on the natural environment for their livelihoods. Indeed, climate change threatens to significantly undermine efforts to achieve the Millennium Development Goals. Assisting developing countries with their efforts to cope with the impacts of global climate change and to create more sustainable, less greenhouse gas intensive development paths is an important focus for UNDP.

Major new investments will be needed over the next 15 years to tackle a wide range of environmental issues that are central to developing countries ability to eliminate poverty and reach the MDGs by 2015.

A recent report commissioned by the Poverty-Environment Partnership - a network of more than 30 international development and environment 
organizations - estimates that US $\$ 60-90$ billion per year will be required to address the environmental issues that bear most directly on poverty reduction in developing countries. Historically, sustainable energy and environment related activities have constituted only a small percentage of total official development assistance, or around US $\$ 3-5$ billion per year in recent years. Clearly, additional financing mechanisms will be needed to fill the gap.

In the compliance sector, the Kyoto Protocol, through the Clean Development Mechanism (CDM) and Joint Implementation (JI), has, in a very short time, spurred a rapidly expanding, multibillion-dollar international market. Financial flows from emission offsets markets could become a major source of financing for sustainable development. In its design, the CDM was intended to offer significant benefits for developing countries in terms of increased capital flows, additional technology transfers and reduced costs of achieving sustainable development objectives. However, early signs indicate that the CDM is unlikely to deliver the broad-based benefits that many expected it would, at least in the near to medium term. Finally, UNDP believes that much more needs to be done to direct carbon finance to a higher number of developing countries, as well as to a broader range of activities that can provide real sustainable development benefits.

\subsection{The United Nations Millennium Campaign}

One of the United Nations Millennium Campaigns is the "End poverty 2015 Millennium Campaign", which aims to reduce poverty; achieving sustained development must be done in conjunction with a healthy planet. The Millennium Goals recognize that environmental sustainability is part of global economic and social well-being. Unfortunately exploitation of natural resources such as forests, land, water, and fisheries-often by the powerful few-have caused alarming changes in our natural world in recent decades, often harming the most vulnerable people in the world who depend on natural resources for their livelihood. 


\subsection{Millennium Ecosystem Assessment}

The Millennium Ecosystem Assessment set out to assess the consequences of ecosystem change for human well-being and to establish the scientific basis for actions needed to enhance the conservation and sustainable use of ecosystems and their contributions to human well-being. Biological diversity plays a critical role in underpinning ecosystem services. Governments supported the establishment of the Millennium Ecosystem Assessment through decisions taken by the Convention on Biological Diversity and other international conventions. The Millennium Ecosystem Assessment was initiated in 2001 under the auspices of the United Nations and governed by a multi-stakeholder board that included representatives of international institutions, governments, indigenous peoples, NGOs, and business. More than 1,360 scientists from 95 countries contributed to the assessment. (Millennium Ecosystem Assessment, 2005).

\subsection{National legislation on protection of forest resources in Vanuatu}

Natural resources in Vanuatu are generally managed under a sector approach. This means that different issues (such as forestry, water quality and threatened species) are dealt with under different laws and by different government agencies. There are several legislation and agencies that are responsible for managing various environmental issues.

The Constitution declares in Article 78 that the government may own land acquired by it in the public interest.

Under the Land Reform Act the minister may, on the advice of the Council of Ministers, order vest any public land of indigenous citizens or communities in accordance with Article 79 of the Constitution, subject to the payment of compensation to the customary owners.

The Environmental Management and Conservation Act 2002 provides for the conservation and sustainable management of Vanuatu's environment. 
"Environment" is defined to include land, water, air, people, animals, plants and minerals. There are three main elements related to these laws:

- Environmental Impact Assessments look at the potential impacts of an activity on the environment and how to avoid, reduce or manage these impacts. Any activity that may harm the environment must be subject to an Environmental Impact Assessment before it can be approved.

- Unless you have Bioprospecting Permits from the Biodiversity Advisory Council, one must not carry out bioprospecting activities (such as collecting natural resources for scientific research or commercial product development)

- Community Conservation Areas. Custom landowners can apply to the Director of Environment to protect the environmental values of an area by registering it as a Community Conservation Areas.

The Forestry Act 2001 provides for the sustainable management of forests in Vanuatu, including a licensing system for commercial harvesting. Specific environmental provisions of the Act include:

- Conservation Areas and Protected Plant Species. No commercial forestry operations can be carried out in a declared Conservation Area. The Minister can also declare particular plants to be protected species, which cannot be harvested without a license.

- Restrictions on Logging Operations. All forestry operations must comply with the Vanuatu Code of Logging Practice, which sets rules for buffer areas, water protection and erosions control. 


\section{The perception of the Forestry Department of forests}

According to the provincial environmental officer of the Forestry Department, the role of the forestry officer is to monitor the loggers. The operations are reduced because of the shortage of resources.

In general, the role of the Forestry Department is to be responsible for the forest and to promote forest timber products (value adding products). For example, if investors are interested of producing timber, the Forestry Department will facilitate the investor in doing value adding products and give marketing information. The main investors are from Japan, New Caledonia and Australia.

There is a main concentration on two specific species: the white wood and the " milk tree" which are dedicated to timber. The two main logging companies in operation in Santo are the Mil coffee sawmill (from New Zealand) and Santapo sawmill (from New Caledonia).

The aim of the Forestry Department is to operate in a more sustainable way, to r pollution) and to insure that d size).

th positive initiatives such as for timber licenses, business

arried out by the Forestry ugh de reforestation charges. ment are the Pacific German ars, has finished in December ronmental Program) and the

or coming on in the future, in ent of Agriculture. Now, the reduce envïronmental impacts (soil erosion and wat timber exports good quality and gets treated (requir

The Forestry Department has been involved w the fact that the sawmill companies have to pay licenses, reforestation charges and export payment.

After logging, reforestation activities are Department. Indirectly, the costs are covered thrc The forestry projects which are on-going at the m forestry project (that has been active for over $10 \mathrm{yt}$ 2007), the SPREP (South Pacific Regional Env Australian replanting project.

There is an oil palm project which is currently Santo. It is under the supervision of the Departn 
Forestry Department is taking care of it by facilitating the oil palm project. Oil palm is an economic and political issue, which conducts economic growth.

The Forestry Department has a good relation with the communities as for example through the implementation of tree replanting programs. The problem with reforestation programs is that the lands are owned by indigenous landowners. They are more concentrated on cash-cropping and not on forest issues because trees take many years to grow and have value. A solution to this problem would be that the government should have their own lands to be able to do what they want to do on them.

According to the perception of the provincial environmental officer of the Forestry Department on the forest is that: "there are less and less forests, we are therefore running out of resources. The forest is now in the mountains, further away than before. To extract the timber, there is a need to do careful plans. In South Santo, there are some problems with the rivers (floods)".

After having seen the global background of this research, we will be introduced to the geographical contact in the following chapter. 


\section{GEOGRAPHICAL CONTEXT}

\subsection{Vanuatu Islands}

\section{a) General description}

The Republic of Vanuatu is an island nation located in the South Pacific Ocean, which is an archipelago composed of 83 islands. The country is divided into 6 Provinces. The archipelago, which is of volcanic origin, lies some $1,750 \mathrm{~km}$ east of northern Australia and $500 \mathrm{~km}$ north-east of New Caledonia. Vanuatu was first inhabited by Melanesian people. Europeans began to settle in the area in the late 18 th century. In the $1880 \mathrm{~s}$, France and the United Kingdom claimed parts of the country and in 1906 they agreed on a framework for jointly managing the archipelago through a British-French Condominium as the New Hebrides. An independence movement was established in the 1970 s. On the $30^{\text {th }}$ of July 1980 , Vanuatu achieved independence from France and the UK. It is a republic headed by a president, with a Prime Minister.

\section{Figure 3:The Vanuatu flag}

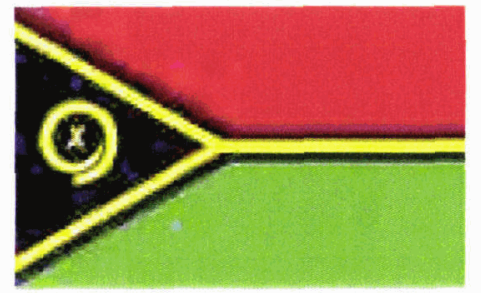

Source: www.wikipedia.org/wiki/Flag_of_Vanuatu

According to Fien and Passingham (2002, p.65), "although tourist brochures promote the South Pacific as an 'untouched paradise', the natural environment is increasingly coming under pressure. Rapid economic changes, population shifts, urbanization and the over-exploitation of resources have resulted in numerous threats to the environment, including coral reef degradation, deforestation, species depletion and water pollution". 


\section{b) Geography of the zone}

The total land area is $12,336 \mathrm{~km} 2$. The climate varies from wet tropical to drysubtropical, with an average maximum temperature range, between 21-27 C, and with an average annual rainfall which declines from $4000 \mathrm{~mm}$ to $1500 \mathrm{~mm}$, from North to South.

There are relatively low levels of diversity or endemicity of terrestrial species and an extensive coral reef ecosystem, with high biodiversity. Most of the islands are mountainous, of volcanic origin and have a tropical or sub-tropical climate. The nation's largest towns are the capital Port Vila (Efate) and Luganville (Espiritu Santo). Vanuatu is recognized as a distinct terrestrial ecoregion, known as the Vanuatu rain forests. It is part of the Australasia ecozone, which includes New Caledonia, the Solomon Islands, Australia, New Guinea, and New Zealand. Natural disasters such as cyclones, seisms and volcanic eruptions have impacts on the development of a rich biodiversity as they induce frequent damages. 
Figure 4: Map of Vanuatu

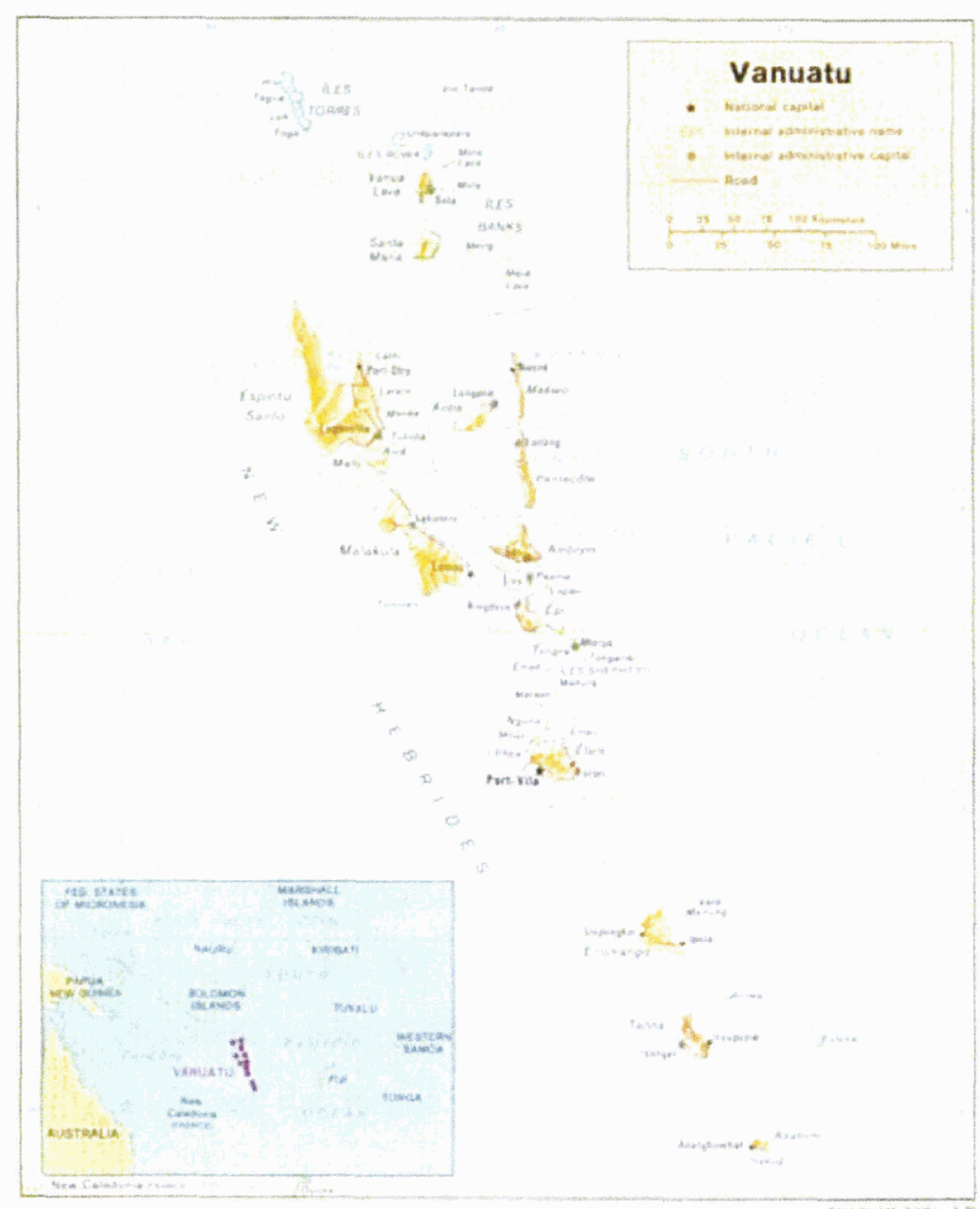

Source: WwW.unesco.org

\subsection{The Vanuatu economy}

The country's economy is based primarily on subsistence or small-scale agriculture, which provides a living for $65 \%$ of the population. Fishing, cattle farming, offshore financial services, and tourism (with about 50,000 visitors in 1997) are other mainstays of the economy. Mineral deposits are negligible. The country has no known petroleum deposits. A small light-industry sector caters to the local market. Tax revenues come mainly from import duties and a $12.5 \%$ VAT on goods and services. Economic development is hindered by dependence on relatively few commodity exports, vulnerability to natural disasters, and long distances between constituent islands and from main markets. 
Vanuatu is a tax haven that until 2008 did not release account information to other governments or law-enforcement agencies. International pressure, mainly from Australia, influenced the Vanuatu government to begin adhering to international norms to improve transparency. In Vanuatu, there is no income tax, no withholding tax, no capital gains tax, no inheritance taxes, nor exchange controls. A disproportionately large number of ship-management companies choose to register their ships under the Vanuatu flag, because of the tax benefits and favourable labor laws.

\subsection{The context of development}

Since 1980 Australia, the United Kingdom, France, and New Zealand have provided the bulk of Vanuatu's development aid. Direct aid from the United Kingdom to Vanuatu ceased in 2005 following the decision by the UK to no longer focus on the Pacific. However, more recently new donors such as the Millennium Challenge Account (MCA) and the People's Republic of China have been providing increased amounts of aid funding. In 2005 the MCA announced that Vanuatu was one of the first 15 countries in the world selected to receive support an amount of US\$65 million was given for the provision and upgrading of key pieces of public infrastructure.

\subsection{Indicators of Human Development}

In 2006, the New Economics Foundation and Friends of the Earth environmentalist group rated Vanuatu as the happiest place to live out of 178 nations all over the world using the Happy Planet Index, which is an innovative new measure that shows the ecological efficiency with which human well-being is delivered. It is the first ever index to combine environmental impact with human wellbeing to measure the environmental efficiency with which country by country, people live long and happy lives. Analyzing its results could help us to move towards a world where we can all live good lives without costing the earth. (http://www.happyplanetindex.org/). 


\section{a) Population}

According to the Vanuatu Statistics Office, the resident population of Vanuatu in 1999 was 186,678 . Now, Vanuatu has a population of 221,506. Nearly the majority of the population of the country is of Ni-Vanuatu ethnicity (98.7\%). The population of the urban regions such as Port Vila, has increased by threefold in 20 years, from 10,601 in 1979 to 29,356 in 1999. The population of Luganville has doubled its population in the same amount of time (from 5,513 in 1979 to 10,738 in 1999). (Table1)

\section{b) Education}

In Vanuatu, almost half (42.7\%) of the population is under 15 years old and only 3,4\% is 65 years old and over. In 1999, 20\% of the population aged 15 had never been to school. The number of students reaching high level of education is very low. The percentage attending school in Vanuatu is low, particularly in rural areas. The proportion of children aged between 6 and 16 years old, living in urban areas have better school attendance. Of the age group 6-16, years old, $75.8 \%$ of males were attending school at the time of the Census compared to $75.5 \%$ of females.

Moreover, the access to education for children is limited and school attendance is not compulsory. Less than $35 \%$ of all children advanced beyond elementary school, due to a shortage of schools and teachers beyond grade six. Boys tended to receive more education than girls. Although attendance rates were similar in the early primary grades (approximately 79\% for boys and $78 \%$ for girls), fewer girls advanced to the higher grades. A significant portion of the population, perhaps as high as $50 \%$, is functionally illiterate.

The Government has few resources for medical care, particularly in outlying provinces where there are no hospitals. NGOs and law enforcement agencies reported increased complaints of incest and rape of children in recent years but no statistics were available. Children generally were protected within the traditional extended family system. Members of the extended family, particularly paternal 
uncles, played an active role in a child's development. Virtually no children were homeless or abandoned.

\section{c) Gender and health}

Over a period of 20 years, the Ni-Vanuatu Total Fertility Rate has lowered by two points: in 1999 there was an average of 4.5 children per woman, compared to 6.5 in 1979. There have been important improvements made concerning health and education as represented in the Ni-Vanuatu Infant Mortality Rate per 10,000, that has lowered 75 points in 20 years: in 1979 the infant mortality reached a high rate of 94 per 10,000 and in 1999 the rate was only 25 per 10,000. Moreover, concerning water and sanitation issues, in the rural areas, the main sources of drinking water were from rivers, spring and wells $(26.0 \%)$, shared piped water (19.3\%), community water tanks $(18.5 \%)$ and household water tanks $(15.9 \%)$. Whereas, in urban areas, almost half of the households had water piped directly to the house (49.6\%), and $28.6 \%$ shared piped water supply and community and household water tanks (11\%). (Table 2)

\section{d) Languages}

In Vanuatu, 108 languages are spoken. The three main official languages in Vanuatu are English, French and Bislama. Local island languages are most used at home $(73.1 \%)$. Whereas urban and rural areas have contrasting proportions, in rural areas, $85.4 \%$ of households speak a local language as their main language, followed by Bislama (13.3\%). In urban areas, it is the other way around. The majority of households speak Bislama as their main language (58.0\%), which is followed by the local languages (30.1\%). 
Table 1: The Vanuatu Population Summary

\begin{tabular}{|c|c|c|c|}
\hline Characteristic & 1979 & 1989 & 1999 \\
\hline Resident Population & 111.251 & 142,419 & 186,678 \\
\hline Male & 59,074 & 73,384 & 95,682 \\
\hline Female & 52,177 & 69,035 & 90,996 \\
\hline Ni-Vanuatu ethnicity & 104,371 & 139,475 & 184,329 \\
\hline $\begin{array}{l}\text { Residents of other } \\
\text { ethnic groups }\end{array}$ & 6,880 & 2,944 & 2,349 \\
\hline Regions & & & \\
\hline Urban & 15,784 & 25,870 & 40,094 \\
\hline Port Vila & 10,601 & 18,905 & 29,356 \\
\hline Luganville & 5,513 & 6,965 & 10,738 \\
\hline Rural $_{2}$ & 95,467 & 16,549 & 146,584 \\
\hline Malampa & 23,567 & 28,174 & 32,705 \\
\hline Penama & 18,937 & 22,281 & 26,646 \\
\hline Sanma & 19,423 & 25,542 & 36,084 \\
\hline Shefa & 126,860 & 38,023 & 54,439 \\
\hline Tafea & 17,506 & 22,414 & 29,047 \\
\hline Torba & 4,958 & 5,985 & 7,757 \\
\hline
\end{tabular}

Notes 1 Estimates

2 Population for the urban areas are included in the respective provinces (Shefa and Sanma)

Source: Vanuatu Statistics Office (www.vanuatustatistics.gov.vu) 
Table 2: The Vanuatu Vital Statistics

\begin{tabular}{|l|r|r|r|}
\hline VITAL STATISTICS & $\mathbf{1 9 7 9}$ & $\mathbf{1 9 8 9}$ & $\mathbf{1 9 9 9}$ \\
\hline $\begin{array}{l}\text { Ni-Vanuatu Crude Birth Rate per } \\
1,000\end{array}$ & 45 & 37 & 33 \\
\hline Ni-Vanuatu Total Fertility Rate & 6.5 & 5.3 & 4.5 \\
\hline $\begin{array}{l}\text { Ni-Vanuatu Infant Mortality } \\
\text { Rate per } 10,000\end{array}$ & 94 & 45 & 25 \\
\hline
\end{tabular}

Source: Vanuatu Statistics Office (www.vanuatustatistics.gov.vu)

\subsection{General information on community life in the South Pacific islands}

In the countries of the South Pacific, "most people live in villages on widely dispersed and remote islands. Transport and communication systems between villages and islands are poorly developed". (Fien and Passingham, 2002, p.66). The South Pacific societies are oral based where storytelling continues to be an important way in which information is shared. Some communities have access to radio and this is often the only source of news and information on social, health and environmental issues. In rural areas, the understanding of English and French is limited.

"The dominant message of most movies and programs is the promotion of an unattainable and unsustainable consumerism. In such circumstances, where information is scarce, educational levels low and communication difficult, community theatre can be an accessible and appropriate means both, education and entertainment. Being both oral and highly visual, community theatre can make ideas and information available to a wide range of people, including the poorest, the most disadvantaged and the most remote ... As a result, community theatre has the potential to be an effective medium for community learning" (Fien and Passingham, 2002, p.66). 
"Some communities are developing village-level initiatives to generate the resources needed to participate in the money economy." The influence of modernization and of globalization has negative consequence on these societies as it "increases their temptations from commercial interests, often from overseas, are difficult to resist even when there is an intuitive understanding that they are offering quick but often minimal rewards in return for allowing the exploitation of their resources". (Fien and Passingham, 2002, p.66).

However, gardening and gathering food and other resources from the forests and reefs remain vital for most people's livelihoods and a strong link between environmental degradation and poverty is increasingly apparent. (Fien and Passingham, 2002, p.65).

\subsection{The island of Espiritu Santo}

The island of Espiritu Santo (from the Spanish espíritu santo, "holy Spirit", sometimes called just Santo) is the largest island of Vanuatu, with a surface area of $4,010 \mathrm{~km}^{2}$. It lies in the Sanma Province of Vanuatu. The town of Luganville, on Espiritu Santo's southeast coast, is Vanuatu's second-largest settlement and the provincial capital. Roads run north and west from Luganville, but most of the island is far from the limited road network. Due to its size and its mountains, Espiritu Santo has the greatest expanses of original rainforest home to a large numbers of birds and beautiful orchids. Huge kauri trees still grow in the southwest mountain forests. In the north, Big Bay conservation area (Vanuatu's first National Park) is the first step to ensure this beautiful island will remain pristine.

The local people survive by supporting the tourist trade, by cash-crop farming (peanuts) or by subsistence farming and fishing. For almost all Santo people custom plays a large part in their lives, regardless of their religion. The chiefly system continues strongly in most areas. Several diseases are present in Santo such as malaria, tuberculosis and a rising number of HIV cases. Although there is a hospital, most locals consult either their own witch doctor or medical clinics set up by western missionaries. Kava is the popular drug of the island, although 
alcohol is becoming more prevalent. With the rising number of adults using alcohol, there is a rising crime rate, especially involving violence toward women, and tribal warfare.

Finally, many local people still rely on subsistence farming for their food. Most villages have a garden that is tended by men and women alike. Taro and yams are commonly grown in these gardens, and are mainstays of the local diet.

\section{Figure 5: The community of Butmas}

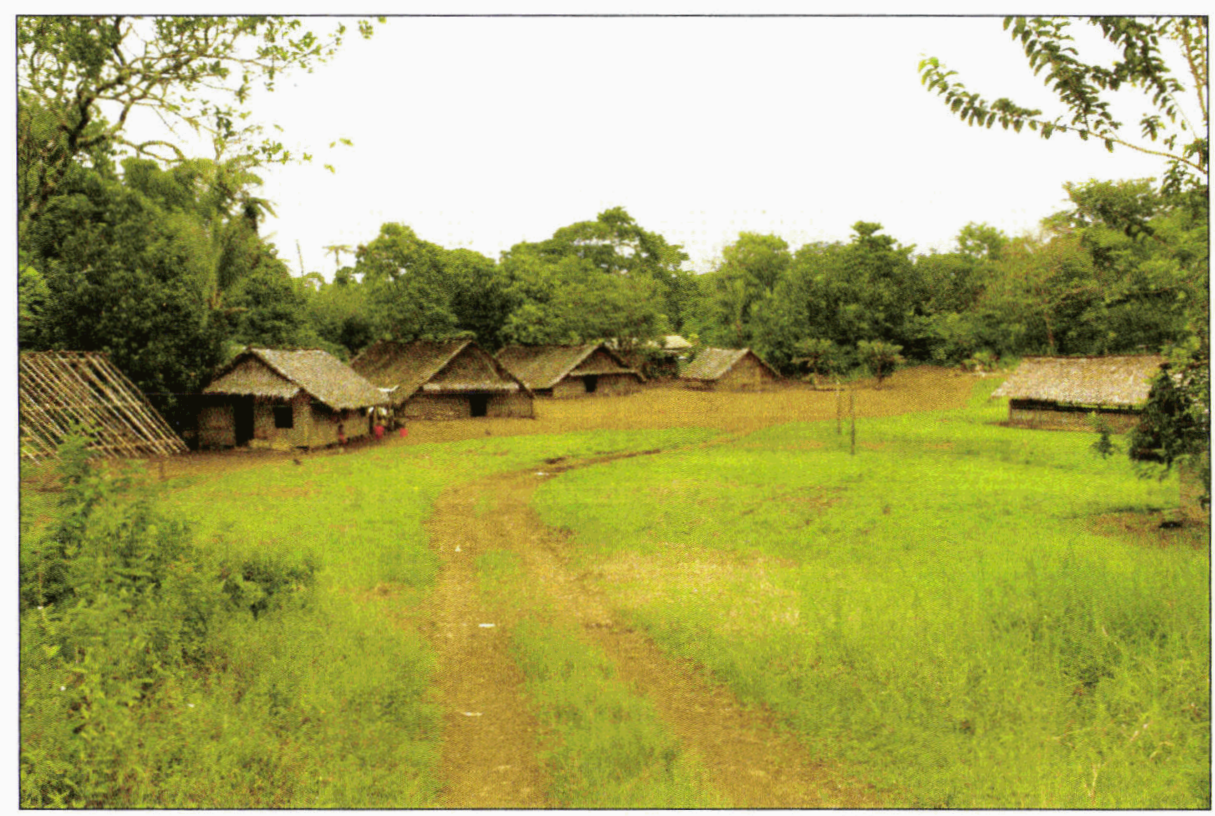

Source: Photo taken by Sarah Brikke 


\section{METHODOLOGY}

\subsection{A qualitative and participatory methodology}

In order to address the gendered research aims of this proposal, a qualitative and participatory methodology has been adopted. Local women were be empowered to contribute to all stages of this research project and express their voices in ethical and respectful ways. Emergent collaborative research relationships allowed this research to be mutually beneficial.

The methodology will be sensitive to women's experience and perspective, while paying due attention to indigenous knowledge and participation.

As a reminder, this research has been done in collaboration with this NGO (working as a volunteer on this project. Based in Port Vila, Vanuatu), which influenced the choice of the communities and the choice of the methodology of this research, such as the use of RAP (Rapid Assessment of Perceptions, explained in the introduction) and Education for Sustainable Development (ESD). As this research is based on women's perception, the results are to be interpreted with a margin of error due to subjectivity and qualitative character of the responses.

This approach will be pursued using qualitative participatory methods at a household- and community level, such as semi-structured interviews, focus groups, surveys, questionnaires, environmental education/awareness workshops, resource mapping and informal discussions with community members.

Furthermore, this participatory approach provided an opportunity for communities to share and create new knowledge. The aim is to 'start from where the community is at', rather than from the outsiders' perspective. There are innumerable examples of well-meaning development programs that fail due to the disconnection between what development or aid workers believe is important, and the actual values, needs and concerns of communities. The intention is to use the 
results that are relevant to make use of existing opportunities, and avoid unintended or negative impacts on the community. (Live \& Learn, 2007).

In addition, according to Bryman and Burgess, (1999) qualitative research is characterized by three commitments:

First, it seeks to understand the world through interacting with, empathizing with and interpreting the actions and perceptions of its actors. Qualitative methods are used to explore the meanings of people's worlds ... and the nature and causes of individual behaviour.

Second, qualitative research tends to collect data in natural settings, rather than artificial and constructed contexts (such as laboratories).

And third, it tends to generate theory rather than testing it. Qualitative method work inductively, builds up theory from observations rather than deductively, and tests theories by trying to refute their propositions.

As a reminder, we do not focalize on mathematical results, we do not seek to obtain data for a statistic evaluation, but a photography of the opinion of the environment. We want to obtain results that are representative of the whole group (Decoudras, 1997).

Finally, a bibliographical research will be carried out at the beginning of the investigation and the information collected at field level will constitute the basis for the analysis.

\subsection{Ethical issues}

As a feminist geographer, I followed research methodologies that provided strict ethical guidelines. I tried to be transparent in regards to my positionality and accountable to my research participants.

Research participants were asked to sign Informed Consent Forms that indicated the nature and intent of the research and explained how their anonymity and the confidentiality of their contributions was going to be ensured.

A summary of the results will be given to the participants (if requested) and copies of the completed research output will be available from the School of 
Geography, Environment and Earth Sciences Library, and in the Victoria University of Wellington electronic database of theses.

\subsection{The principal informants}

\section{a) The sampling / election of the local communities}

The communities of Monxhill and Butmas were chosen by Live and Learn Environmental Education to participate in the forest research in order to continue working with them towards possible further forest programs including on a carbon trading scheme. Also financial issues have been taken into account, due to their proximity and accessibility. Luganville is 15 minutes ride from Monxhill (approximately $10 \mathrm{~km}$ ) and Butmas 2 hours from Luganville (approximately $50 \mathrm{~km})$. Moreover, the nonexistence of land disputes was part of the selection and other issues relating to land such, as for example, the logging and foreign investment showing interest to landowners and then buying land at very cheap price. Other communities could have been selected to actually participate in this research, but due to the above mentioned constraints, that was not possible.

\section{b) The specific case of women and youth}

Due to the fact that most of the men were unavailable because they were working in their gardens every day, we chose to focus ourselves on the available population in the communities, which were the adult women and young women. It was a good way for the women to express themselves as there weren't any men present. They would have been much more shy and not as communicative if men had been present. 
Figure 6: Women and youth group (Butmas)

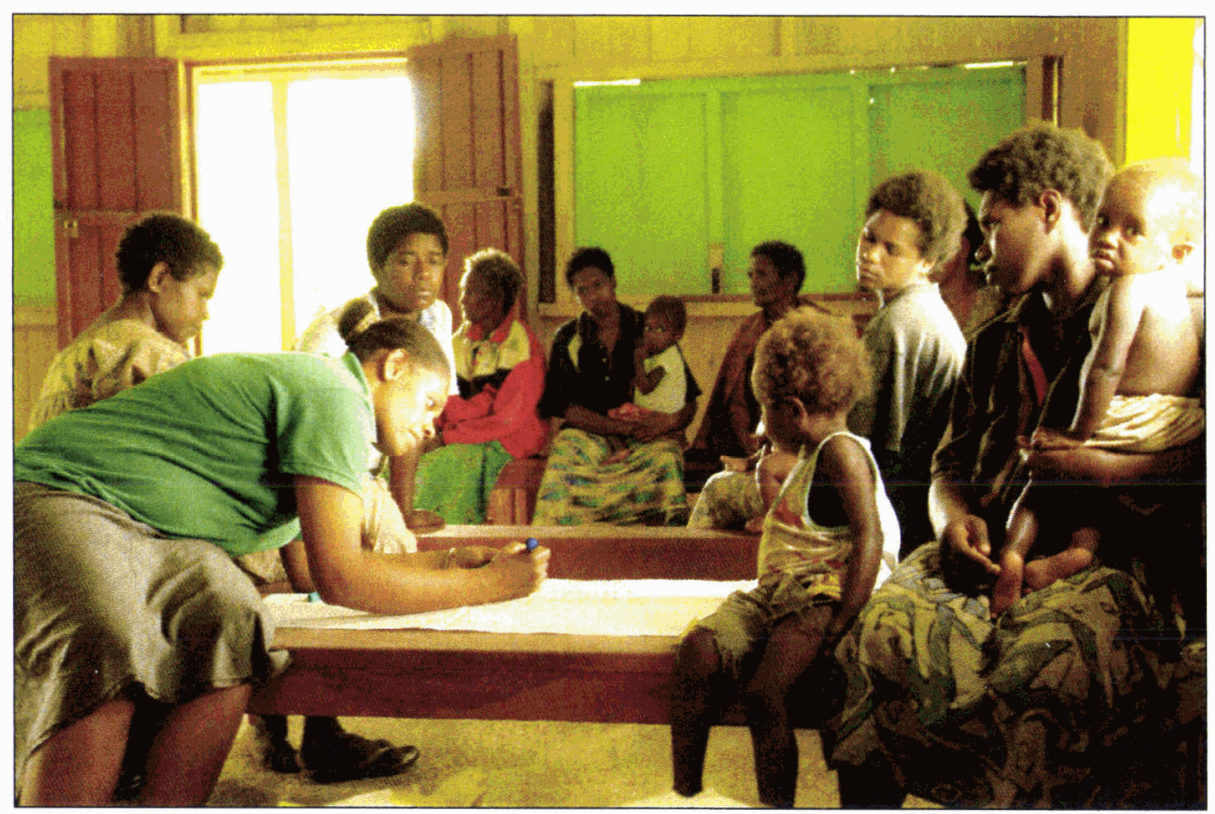

Source: Photo taken by Sarah Brikke

\subsection{The information and recollection tools}

\section{a) The different types of observation}

During the gathering of information on the field, it was important to minimize the researcher's impact on his/her observations. In order to be able to do that, different methods were used such as: observation, interrogation, listening and coding of the responses. For example, the 'observation of behavior of man in its environment' constitutes the basical method of all perception of environment approaches. Whereas, the 'indirect observation' looks at the effects of man in order to evaluate their behaviour and then elaborate practical recommendations.

Moreover, margins of error can be lowered by asking people to have a judgment on the same data. For example, the fact that 'nothing happens' is still an 'event' and is considered as a valid data to register.

The 'participative observation' method adapts itself very well in the field, especially concerning researches based on the perception of the environment. In this type of observation, direct observation, interrogation, and listening are associated at the same time that the researcher takes part in the life and activities 
of the local population that he/she studies. In consequence, the researcher plays two roles: the role of observer and participant. His/her job in the field, consists in being introduced into the existence of the participants of the research, to talk to them and to gather detailed notes. "The participative observation method requires the researcher to be immersed in the place and/or the society he/she is studying. By living closely with these people, it is possible to emphasize with their way of looking at and interpreting their world. ... Some people's worlds are hard and unpleasant to experience. It requires great effort and determination to learn their language and to understand what people mean." (Scheyvens and Storey, 2006, p.59).

The participant can take advantage of the benefits of a study on perception through four different ways. Indeed, this research can help:

- To be aware of certain possibilities which were until now ignored or not sufficiently appreciated;

- To be prepared for perspectives that were until now ignored;

- To understand and appreciate different points of view, that don't always match with our personal point of view;

- And even better, this research can play the role of stimulation for new and more efficient actions in management and/or in protection and conservation of the environment.

\section{b) Questionnaires / semi-structured interviews}

The questions asked to the participants are stated in the Appendix 9. The results of the questionnaire had to be interpreted with a margin of error and with cautiousness as they were based on the perceptions which are subjective.

In order to make the participant at ease and to be able to answer in trust, without suspicion, the researcher started the discussion talking about diverse subjects without any specific links to the research. Finally, the questions were targeted, which obliged the participant to make an effort of reflection. 
The interviews were conducted on a one to one basis (individual) with women such as the president of the Santo Women's Committee (SWC), Community Committee and Youth Clubs. The information collected from the questionnaire is a direct expression of the participant's perception. In order to respect the personal perception of each participant, the researcher tried its best not to involve any external intervention or disturbing elements that could have altered the information given during the interview.

The role of the researcher during the interview was to supervise the discussion with the help of key words and a list of questions. The participants answered the question and developed their personal ideas. The researcher tried to intervene as less as possible in order not to influence the participant's views. Therefore, each response and each questionnaire corresponds to the perception of one person, who can incorporate the opinion of an institution, an organism or a group of people.

\section{c) Mental maps: resource mapping}

The objective of participatory mapping (appendix 4) by the village communities, is to engage in problem solving, analysis, appraisal, planning and decision-making ... Indeed, when different sectors of the population make their own separate maps, they reveal very different perceptions of a problem or situation. If each group presents their map to an assembly, voice can be given to those coming from the more marginalized sectors of the population, who are usually silent in the development process (Shah, 1997, p.84). It is therefore a good tool for the women to express themselves. It is also an accurate tool in an environment where illiteracy is prominent.

According to Shah (1997, p.91), (this method) has helped local people to make a resource inventory, use indigenous knowledge and undertake problem identification and analysis.

The process of mapping has also proved to be a useful mechanism for conflict resolution and participatory decision-making ... and is useful for better targeting 
and effective implementation and management of development programs. It has been our experience that it is difficult to get responses by direct questioning on a number of complex issues. However, people do not feel threatened to respond on these issues while diagramming (Shah, 1997, p.93).

This tool is designed to get participants to visually represent an area as they see it. Mapping may not necessarily be about accuracy, as it is based on perception. Mapping can serve to highlight group dynamics and perceptions, as people discuss the way they see an area. Drawing on the map encourages people to think more about a particular issue and offers another way of expressing their views visually.

Moreover, this tool can be used to promote increased thought and discussion on issues and can help to gain several layers of information in a very useable format. This tool is used to gain physical information about an area, through participant observation and facilitator questioning. It is an external activity where the participants walk along a designated course through an area. The concept is for the participants to consciously look at their physical environment with a key focus such as water, resources, problems and solutions (Live and Learn, 2006).

\section{d) Ranking exercise}

Ranking (appendix 6) allows the participants to work through the issues and as a group prioritize them into a ranked order. This leads to group discussion about perceptions of importance. More issues may also arise as participants explain the importance of different issues. Prior to ranking, the issues need to be highlighted by the group. Listing is a documentation tool that requires the participants to list what they see as the key issues. (Live and Learn, 2006).

\subsection{Encountered problems}

The main problem during this field research was the lack of communication, lack of motivation and timidity of the participants. "One of the errors that can be made when several entities have to communicate together is to select the wrong 
methods to communicate - most commonly choosing one-way, transmission based methods would be more suitable or having a distorted and biased view of 'the others' and not bothering to find out what they are really like." (JonesWalters, 2000, p.26).

Moreover, several specific "problems can occur in communicating about nature conservation, as nature means different things to different people and that conservationists see themselves as the experts when it comes to nature and tend to assume that the ideas other groups have about nature are wrong ... (In addition) there exists a 'no good news' factor about nature conservation." (Jones-Walters, 2000).

According to the fact that the subject of deforestation is polemic, several people didn't reveal themselves as being cooperative nor communicative and preferred not to answer certain questions.

Some participants were not conscious or were not interested by the destiny of the forest on their island or in Vanuatu. Others wouldn't talk about it or wouldn't say everything they knew about the subject, because they were shy or because they didn't feel like speaking to the researcher. In a situation of distrust, the participant doesn't feel free to speak. The results of several spontaneous interviews showed that a discourse could vary considerably according to the image produced by the research (which reinforces the fundamental notion of 'positionality' in research).

It seems that the first quality that a participant looks for in the researcher is: capacity to listen and human contact. It is preferable to choose to do individual interviews rather than group interviews, in order to allow the participant to express himself/herself freely. In a group, hierarchical contexts, individual timidity, can considerably annihilate the capacity of expression. There are some situations where the participant doesn't speak much, by mistrust, by timidity or because he has other preoccupations or is not available. 
More specifically, as those communities are remote and isolated, the majority of the participants spoke only bislama and didn't speak a lot of English. Therefore, it was essential to work in collaboration with two local staff of Live and Learn Environmental Education, in order to be able to communicate well with the communities (with whom they have already worked since a couple of years) and to be sure that the message was well understood. The questions were exposed in a simple way in bislama, so that everybody could understand.

Unfortunately, the day which we planned to do our meeting with the members of Monxhill community, the Mayor of Luganville, Lord Mayor Jonah died. Therefore, we had to postpone our workshop to another day. The day, we came back, no men were present, as they were all working in their garden, and the only ones who were left were the women. But, the women were very shy, not motivated and could not concentrate due to the distractions caused by the children.

We will now introduce the results and analysis of this research, which have been developed using the methodology mentioned above. 


\section{RESULTS AND ANALYSIS}

\subsection{Needs and concerns}

In order to identify women's perception of their needs and concerns (objective two of this research), women of the communities of Monxhill and Butmas expressed themselves on the needs and concerns of their communities. This process was essential in a participatory research, as the results and analysis of this objective helped us to understand better the communities with whom we were working.

According to the women leaders and women youth group of the Monxhill community, there are several problems concerning their community. These are mainly related to a lack of education and communication in the community, to the misbehaviour of men and to health and financial issues. 
Table 3: List of the needs and concerns of the community (Monxhill)

\begin{tabular}{|c|c|c|}
\hline $\begin{array}{l}\text { Needs and } \\
\text { concerns }\end{array}$ & \multicolumn{2}{|c|}{ Comments } \\
\hline $\begin{array}{c}\text { Lack of } \\
\text { education }\end{array}$ & \multicolumn{2}{|c|}{ "The teacher of the school doesn't do a good job". } \\
\hline $\begin{array}{c}\text { Lack of } \\
\text { communication }\end{array}$ & \multicolumn{2}{|l|}{ "No cooperation in the community". } \\
\hline Financial issues & $\begin{array}{l}\text { "Can't pay the school fees, } \\
\text { therefore the children don't go } \\
\text { to school because the parents } \\
\text { don't have the money". }\end{array}$ & $\begin{array}{l}\text { "There is no other way to } \\
\text { make money that to do the } \\
\text { market. It is our only } \\
\text { solution". }\end{array}$ \\
\hline $\begin{array}{l}\text { Misbehaviour } \\
\text { of men }\end{array}$ & $\begin{array}{l}\text { "The men drink too much kava, } \\
\text { they don't work and don't help } \\
\text { the women". }\end{array}$ & $\begin{array}{l}\text { "The men make the women } \\
\text { pregnant and then they } \\
\text { leave". }\end{array}$ \\
\hline Health issues & $\begin{array}{l}\text { "There is no clinic in the } \\
\text { community". }\end{array}$ & $\begin{array}{l}\text { "The water doesn't run well } \\
\text { through the pipe of the } \\
\text { house". }\end{array}$ \\
\hline
\end{tabular}

\section{a) A lack of education due to financial issues}

Indeed, after having analyzed results of women's perception of Monxhill on the needs and concerns of their community, we can underline that there is a lack of education due to financial issue in the families. The families were unable to send their children to school, as they couldn't afford paying the school fees, due to a shortage of options to earn money except by selling their products on the markets.

Moreover, women's education level was low as most of them had quit school after primary school and only a few continued to secondary school. 
Education teaches you the basis of living in a society, respecting the environment and teaches women how to take care of themselves. The priority in the educational sector would be to educate more women, as they are the key actor for the well being of their families as they ones who take care of the whole family, by cooking, educating, washing ... and they are closer to their children than men, in general, as they take care of their children's hygiene, nutrition, education and health. The lack of education explains also why women have so many children (average of 4 per woman aged between 30 and 35 years old).

\section{b) Problems related to kava drinking}

A recurrent problem in Melanesia was kava drinking. The women of the community of Monxhill all agreed that kava was a major problem in their families, "because women had to endure the laziness of men, and had to do everything in the house, as the men didn't assist their wives in the daily tasks".

Another social problem was that there were a lot of women who raised their children alone, as once they got pregnant, the men usually left the house. Some of the women testified the presence of violence in their lives and said that they were beaten by their husbands. There were many single mothers and therefore a large number of "babies that didn't have a father figure". These young mothers, (with no education or who only went until primary school) faced difficulties raising their children and finding money to pay the school fees.

\section{c) A lack of health commodities and lack of communication}

There are no clinics or health centres in the community. When a child got hurt, there was usually not enough money to go into Luganville to the clinic, so the infections usually got worse.

There was also a lack of communication and cooperation in the community according to these women, there was therefore a strong a need of new initiatives from the current chiefs. "The community has to work as one, where the members 
of the community have to give their views and the chief has to support, endorse and recommend options".

\subsection{Ranking of needs and concerns}

In order to understand better the women's priorities of needs and concerns of their communities, a ranking exercise was done (responding to the second objective of this research: Identify women's perception of their needs and concerns).

According to the lessons learned from previous RAPs (Rapid Assessment of Perceptions), it is important to stress to the participants that there is no right or wrong answer. Sometimes some groups hesitate to do the ranking in case they get it wrong. We explained to them that there were no "right or wrong" answers, that it was just the perceptions of the participants that we wanted to study. This is an activity that can easily turn into a debate where one group tries to beat another.

The ranking of needs and concerns rank from the most to the least important. 
a) Ranking of Monxhill

Table 4: Ranking of the needs (Monxhill)

\begin{tabular}{|c|c|c|}
\hline Ranking & $\begin{array}{l}\text { Women leaders and women } \\
\text { youth group of the Monxhill } \\
\text { community }\end{array}$ & Comments \\
\hline 1 & "A new water tank" & \multirow{3}{*}{$\begin{array}{c}\text { Water, sanitation and } \\
\text { health }\end{array}$} \\
\hline 2 & "More water sealed toilets" & \\
\hline 3 & "A clinic for the community" & \\
\hline 4 & "A women's centre" & \multirow{3}{*}{$\begin{array}{l}\text { Participation, } \\
\text { empowerment and } \\
\text { education }\end{array}$} \\
\hline 5 & $\begin{array}{l}\text { "A trainer to help the women } \\
\text { make a small business (to help } \\
\text { them find new alternatives, and } \\
\text { help them organize themselves)". }\end{array}$ & \\
\hline 6 & $\begin{array}{l}\text { "Literacy class (to learn how to } \\
\text { read)". }\end{array}$ & \\
\hline
\end{tabular}

According to the women leaders and women youth group of the Monxhill community, the ranking of the needs and concerns can be divided into two categories.

On the one hand, the most important needs and concerns of their community are related to water, sanitation and health; and on the other hand, related to participation, empowerment and education.

\section{b) Water, sanitation and health issues (Monxhill)}

First of all, as we said, the three most important needs and concerns (according to women's perception) are related to water, sanitation and health.

Indeed, according to the women leaders and women youth group of the community of Monxhill, the most important need was to "have a new water tank" 
(as the current one is old and not functional), to "have more water", "sealed toilets" and to "have a clinic for the community", "because when the children get hurt or sick there is no place to go".

As one of the women said, "Wota is laef. Sipo no gat wota, no gat lives" (Water is life. If there is no water, there is no life).

This ranking of perceptions of their needs and concerns, translates well their concern at a global level concerning water and sanitation.

\section{c) Participation, empowerment and edu`ation issues (Monxhill)}

The second part of needs and concerns of this community were related to participation, empowerment and education.

Indeed, the women leaders and women youth group of the Monxhill community shared their will to have a Women's Centre, for them to be able to meet between women and to form a group in order to participate in decision making processes. This Women Centre could also help women to have a space where a trainer could teach or help them to make a small business, to help them find new alternatives, and to help them organize themselves, as for example learning how to make handicraft or mats (that they could sell instead or in addition to having to go to the markets to sell their fruits and vegetables).

These women wanted to participate more in the community life and find a way to be more powerful, which could be possible through a process of education and empowerment.

They women expressed their will to be more educated, and therefore expressed the will to have literacy classes (which could be done in the Women's Centre) to learn how to read and write, in order to have a chance to be more educated. Indeed, if you educate a woman, a whole family will be educated. 


\section{d) Ranking of Butmas}

Table 5: Ranking of the needs (Butmas)

\begin{tabular}{|c|c|c|c|}
\hline $\begin{array}{l}\text { Rank- } \\
\text { ing }\end{array}$ & Concerns/problems & Needs & Comments \\
\hline 1 & $\begin{array}{l}\text { "There is no water supply and all the } \\
\text { women have to work very hard, in } \\
\text { order to get the water of the river, to } \\
\text { be able to cook and clean the dirty } \\
\text { clothes of the children". }\end{array}$ & "Need more water supply". & \multirow{3}{*}{$\begin{array}{l}\text { Water, } \\
\text { economy } \\
\text { and health }\end{array}$} \\
\hline 2 & $\begin{array}{l}\text { "There are no alternative ways to earn } \\
\text { money than by doing the market, and } \\
\text { the truck that goes to the market is } \\
\text { much too expensive". }\end{array}$ & $\begin{array}{l}\text { "Teach the women how to } \\
\text { sow or teach them another } \\
\text { activity so that they can earn } \\
\text { money with it (by selling } \\
\text { their handicraft for } \\
\text { example)". }\end{array}$ & \\
\hline 3 & $\begin{array}{l}\text { "There is no access to medicine or aid } \\
\text { post to treat sick people, people don't } \\
\text { have enough money to pay the truck to } \\
\text { go to town to the clinic". }\end{array}$ & $\begin{array}{l}\text { "Need a clinic and/or aid } \\
\text { post". }\end{array}$ & \\
\hline 4 & $\begin{array}{l}\text { "No repairs are done on the building } \\
\text { of the school and the road that goes to } \\
\text { town is in very bad conditions". }\end{array}$ & $\begin{array}{l}\text { "Repair the school and build } \\
\text { a community hall for the } \\
\text { community members to } \\
\text { gather" }\end{array}$ & \multirow{2}{*}{$\begin{array}{l}\text { Infrastructure } \\
\text { empowerment } \\
\text { and } \\
\text { education }\end{array}$} \\
\hline 5 & $\begin{array}{l}\text { "Many women don't have their rights. } \\
\text { There is violence inside the house and } \\
\text { men are the boss. All women work } \\
\text { hard to do the work of everybody, take } \\
\text { care of the children, go to the garden, } \\
\text { get the firewood and then cook". }\end{array}$ & $\begin{array}{l}\text { "Plan training for women to } \\
\text { teach them how to read and } \\
\text { write in order for them to } \\
\text { educate their children and } \\
\text { find a job". }\end{array}$ & \\
\hline
\end{tabular}


According to the women leaders and women's youth group of the Butmas community, the ranking of the needs of the community can be divided into two categories.

\section{e) Water, economy and health issues (Butmas)}

On the one hand, the most important needs are related to water, economy and health issues.

Indeed, (such as in the community of Monxhill), the first need for this community was to have better access to water, because "there is no water supply and all the women have to work very hard in order to get the water of the river, to be able to cook and to clean the dirty clothes of the children".

In addition, a lack of economical opportunities make it difficult for the families to earn money as "there are no alternative ways to earn money than by doing the market, and the truck that goes to the market is much too expensive". Therefore one of the solutions to this problem could be to educate women, in order to "teach the women how to sow or teach them another activity so that they can earn money with it (by selling their handicraft for example)".

Finally, due to the isolation of Butmas and the long distance that separates the community from Luganville, the access to health facilities such as "medicine or aid post to treat sick people" is difficult, "and people don't have enough money to pay the truck to go to town to the clinic". Therefore, the members of the community use traditional medicines and/or go to the local healer when they are sick.

\section{f) Infrastructure, empowerment and education issues (Butmas)}

On the other hand, the other important needs and concerns were related to infrastructure, empowerment and education issues. 
Concerning the infrastructures, "no repairs are done on the building of the school and the road that goes to town is in very bad conditions". The scholl building needs to be repaired (according to women's perception) and the participants were willing to have a community hall where the community members could gather, which translates a desire to have a better participation, cooperation and communication in their community.

A notion of empowerment was expressed by the women of Butmas as they were questioning themselves on their place and role in the community. They felt the need to be more respected, as "many women don't have their rights". "There is violence inside the house and men are the boss. All women work hard to do the work of everybody, take care of the children, go to the garden, get the firewood and then cook".

As in Monxhill these women wanted to be more educated in order to learn how to read and write so that they can "educate their children and find a job."

To conclude on these two first results chapters on women's perception on the needs and concerns of their communities, it is interesting to see that the women's perception on these needs and concerns are very similar between Monxhill and Butmas.

The most important need and concern for both being the issue of water, water being a symbol of life but it can be also symbol of health problems or even death, if education and health facilities are lacking.

Those women seem that have a good knowledge of the needs and concerns of their community, as they understand that education, health and participation are linked and that they represent the main priorities for the wellbeing of their families. 


\subsection{Women's perception of their role in forest conservation issues in Monxhill and Butmas}

This chapter completes the third objective of this research, which was to identify women's perception of their role in forest conservation issues in Monxhill and Butmas.

\section{a) Context of the interviews}

Thanks to semi-structured community interviews (see appendix 9) it was possible to have a better knowledge of the type of relationship between women and nature in Monxhill and Butmas. These interviews were conducted on a one to one basis (individual) with village Chiefs, president of the Santo Women's Committee (SWC), Community Committee and Youth Clubs members.

The quality of comprehension and response of the informants are related to their level of education. As the role of the researcher was to gather the perception of women, external influence had to be as low as possible, in order to be able to have the 'real' perception of the participants. In general, during the interviews, the participants were very quiet, shy and confused, and probably ashamed, which made the gathering of data difficult.

\section{b) Prominent role of chiefs but lack of communication}

After having analyzed the results of this section, it is clear that the role of women in decision- making in forest conservation issues is low, whereas the role of chefs is prominent.

There were several difficulties getting things done in the community, which were related to land and logging issues and a lack of cooperation and communication in the community. It seems that the "chiefs lack in getting things done" (according to the women of Monxhill and Butmas). This lack of 
cooperation and communication between the community members and the chiefs is an important issue, as it is the chief that has a strong power in decision-making.

According to a participant, "the community needs to organize itself better, in order to have a good cooperation. Only the chief is talking to other parties outside the community. Only HE can initiate external discussion or/and agreement".

Moreover, a participant said that "women are active in all community work. They have to work with chiefs. The chief should impose customary rules (fines and penalties) to those who steal or do bad things to community". According to some women "the chief should provide kava and food in order for the community members to perform the work required. In the past only men drink kava, however, currently females also drink kava".

\section{c) Lack of available lands}

Apparently there are not enough lands available which explains a decrease of space reserved for cash-cropping. An informant stated that, "there are no lands because people from other islands are purchasing land. Usually, one hectare is ideal for the subsistence farming but it is relatively small for tree planting. Only chiefs have all the land, he leases land out to other people at $50000 \mathrm{Vt}$ annually".

\section{d) Deforestation issues}

As we can see through the comments of the participants, it seems that the problem of deforestation is present in Monxhill and Butmas. The President of the Santo Women's Committee (SWC) stated that their community has been involved in forestry initiatives such as "deforestation and logging ten years ago, the timber was exported to New Zealand ... The land leases begun in 2005, people from Epi, Ambrym, Ambae, Tongoa, Paama, Efate, Pentecost, including business people, lease the land to the chief'.

"Many trees have been logged and the regeneration of natural seedlings is taking place but cannot grow well due to a high demand of space and food". 
"Accessing to firewood is now an issue, as community members have to walk far to get firewood" (President of the Santo Women's Committee, SWC).

\section{e) Communication about forestry issues}

According to the women of Monxhill, "the community communicates about forestry issues to World Vision, to the forestry department and to the logging companies, in order to follow the proper procedures and with the chiefs". The President of the Santo Women's Committee (SWC) and the member of the Youth Group assure that "the community and the Government authorities have developed a very good dialogue since it started".

On the contrary, according to another participant, "only chiefs deal with the dialogue. We all have to listen. It is the role of the chief to approach the police".

\section{f) What do you do when you go in the forest?}

This question was asked to the women in order to have a better understanding of the different type of activities a woman would do in the forest. "We make gardens, we clear the bush and the forest for cash cropping" (President of the Santo Women's Committee, SWC), "we do some logging and cultivate crops" (Member of Youth Group), "and we bushwalk and listen to the bird's noise" (a participant).

\subsection{Women's perception of their forest resources}

Thanks to the results and analysis of this chapter, the first objective of this research has been attained, which was to identify women's perceptions of the forest in Monxhill and Butmas. 


\section{a) An introduction to the methodology}

Concerning the methodology for this objective, a tool to measure environmental discourse was used in order to give some basis of the participant's view on forests. The aim of this exercise was to determine the views and values that the participants had of the forest.

Participants were initially presented with the six conceptions of the forest described by Sauve (1996), whereby the forest could be considered as: (table 6)

- A community project,

- Nature,

- A resource,

- The whole planet,

- A place to live, or

- A problem to be solved 
Table 6: The six different environmental discourses

\begin{tabular}{|c|c|}
\hline Environmental Discourse & Comments \\
\hline 1. I see the forest as nature & $\begin{array}{l}\text { Environment is everything around us. We see the } \\
\text { nature as the environment. Where there is nature } \\
\text { means there is environment. }\end{array}$ \\
\hline 2. I see the forest as a resource & $\begin{array}{l}\text { I see the forest as a resource. It is to be managed so } \\
\text { that it can provide us with food, materials and } \\
\text { medicines. }\end{array}$ \\
\hline $\begin{array}{l}\text { 3. I see the forest as a problem } \\
\text { which has to be solved }\end{array}$ & $\begin{array}{l}\text { I see the forest as a problem, which has to be solved, } \\
\text { we need to fix up pollution, and over harvesting our } \\
\text { fish and forests. }\end{array}$ \\
\hline $\begin{array}{l}\text { 4. I see the forest as a place to } \\
\text { live }\end{array}$ & $\begin{array}{l}\text { I see the forest as a place to live, to know and to } \\
\text { learn about, to plan for and take care of. The village } \\
\text { and garden is my environment. }\end{array}$ \\
\hline $\begin{array}{l}\text { 5. I see the forest as the whole } \\
\text { planet }\end{array}$ & $\begin{array}{l}\text { I see the forest as the whole planet, where everything } \\
\text { is connected and people are part of this system } \\
\text { (water, air, plants, animals and people). We must all } \\
\text { live together in the environment }\end{array}$ \\
\hline $\begin{array}{l}\text { 6. I see the forest as a } \\
\text { community project }\end{array}$ & $\begin{array}{l}\text { I see the forest as a community project, it's an } \\
\text { opportunity for us to get involved and work together. }\end{array}$ \\
\hline
\end{tabular}

Each group was asked to select the conception that best described how they perceived the forest. The facilitator made sure to say that there were many different ways of perceiving and valuing the forest and made sure that the participants understood that there was no correct or wrong answer to this task, it was just about individual perceptions. They are likely to identify with more than one perception, however the task was to choose the one that they thought would fit their perception best. 


\section{b) Women's perception of their forest resources in Monxhill}

The participant's responses which are represented in the pie, figure 7 , illustrated some diversity in women's perception of their forest resources, but most of the women of Monxhill had a holistic sense of the environment.

The women's perception of the forest can be categorized in three groups, the forest being perceived as a habitat, as nature and finally as something that needs to be respected and protected.

\section{Figure 7: Women's perception of their forest resources in Monxhill}

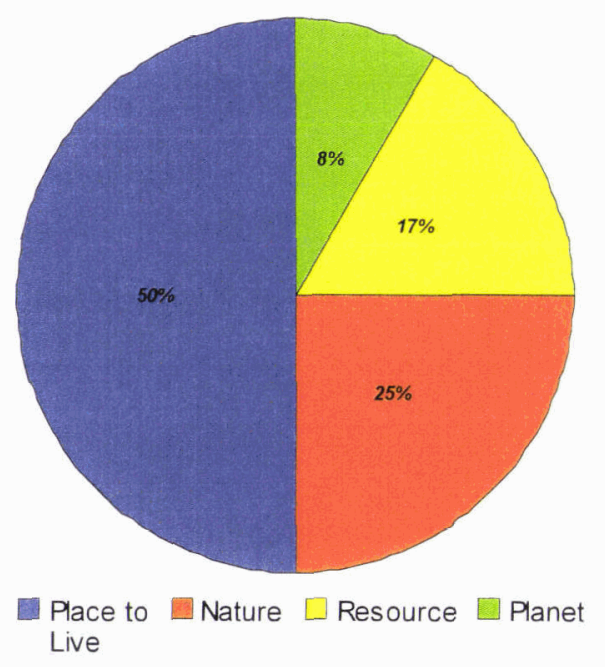

Half of the women of Monxhill perceived their forest resources as being "as a place to live (figure 8), to know and to learn about, to plan for and take care of. The village and garden is my environment". According to the fact that the community is surrounded by nature, they feel the forest to be like their home and that they belong to this natural space. A positive point is that the majority seems to have the need to learn about and to take care of the forest as a priority. 
Figure 8 "I see the forest as a place to live" (Monxhill)

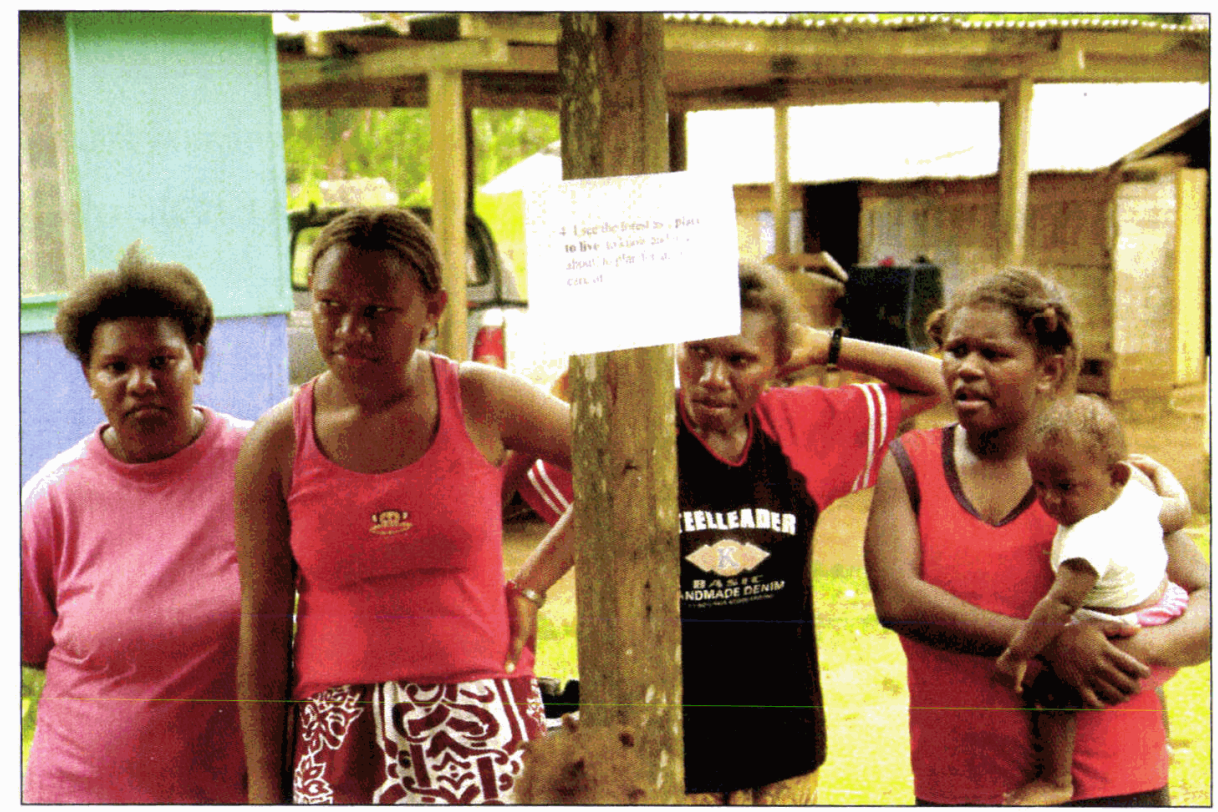

Source: Photo taken by Sarah Brikke

In addition, a quarter of Monxhill's women perceive the forest as nature (figure 9), it "is everything around us. We see the nature as the environment. Where there is nature means there is environment".

Figure 9: "I see the forest as nature" (Monxhill)

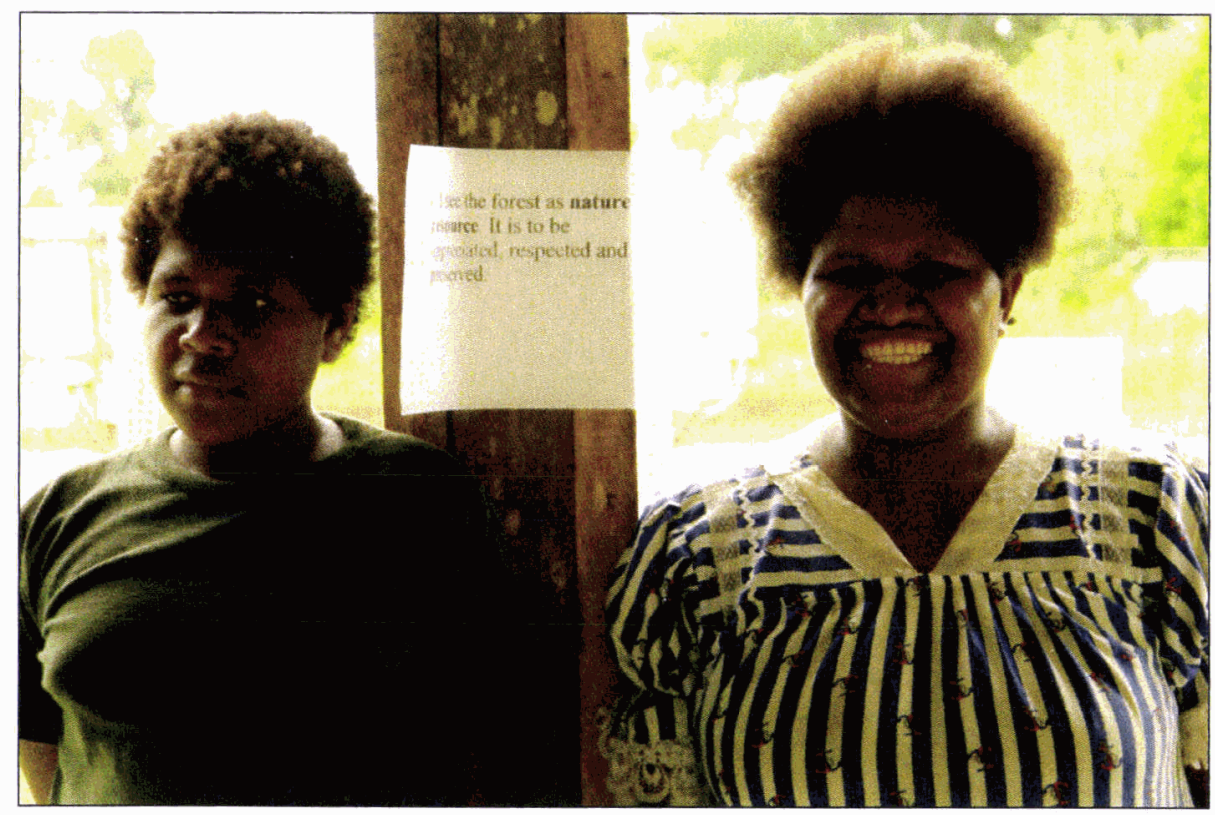

Source: Photo taken by Sarah Brikke 
Moreover, the last represented quarter can be joined together (although it is composed of two different perceptions, $17 \%$ of the women in Monxhill see the forest as a resource and $8 \%$ see it as the whole planet) because it translates well the idea that humans are part of a whole and that forest provide resources such as food, materials and medicine. Therefore, forests need to be respected and protected.

Finally, nobody perceived "the forest as a problem, which has to be solved", putting this way, the problem of deforestation on the side. (Figure 7)

\section{c) Women's perception of their forest resources in Butmas}

More than the half of the women in Butmas perceived the forest as being "a resource. It is to be managed so that it can provide us with food, materials and medicines". This affirmation can be explained by the fact that community of Butmas relates much more in relation with the nature, as they are surrounded with forest. They depend on the fruits of the trees and the water of the river to be able to eat and drink. The forest allows them to live as they can eat, drink, build, and heal (thanks to medicinal plants), using the forests' resources. 


\section{Figure 10: Women's perception of their forest resources in Butmas}

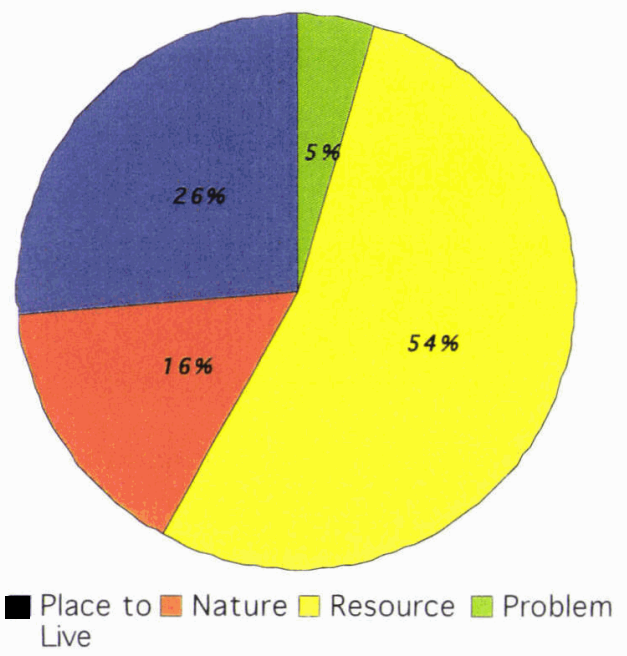

Moreover, according to the fact that this community lives surrounded by forests and that it is remote and isolated, $26 \%$ of the participants perceived the forest "as a place to live, to know and to learn about, to plan for and take care of. The village and garden are my environment". (Figure 10)

In addition, contrary to the participants of Monxhill, 5\% of the women of Butmas believe that the "forest is a problem, which has to be solved, we need to fix up pollution, and over harvesting of our fish and forests". The problems of deforestation and logging are probably more present in this community, therefore the participants feel that something should be done to protect and conserve their forest resources as they are dependent on them to survive. 


\subsection{The evolution of women's perception of their forest resources}

Thanks to the results and analysis of this chapter, the first objective of this research has been attained, which was to identify women's perceptions of the forest in Monxhill and Butmas.

\section{a) An introduction to the methodology}

This methodology was introduced in a study made by the author on the perception of local communities on sea turtles in French Polynesia (Brikke, 2006). This method helps us determine the evolution of perception on the forests, by asking the participants how they perceive the forest in the past, in the present and in the future.

Figure 11: The forest, on the way to Butmas

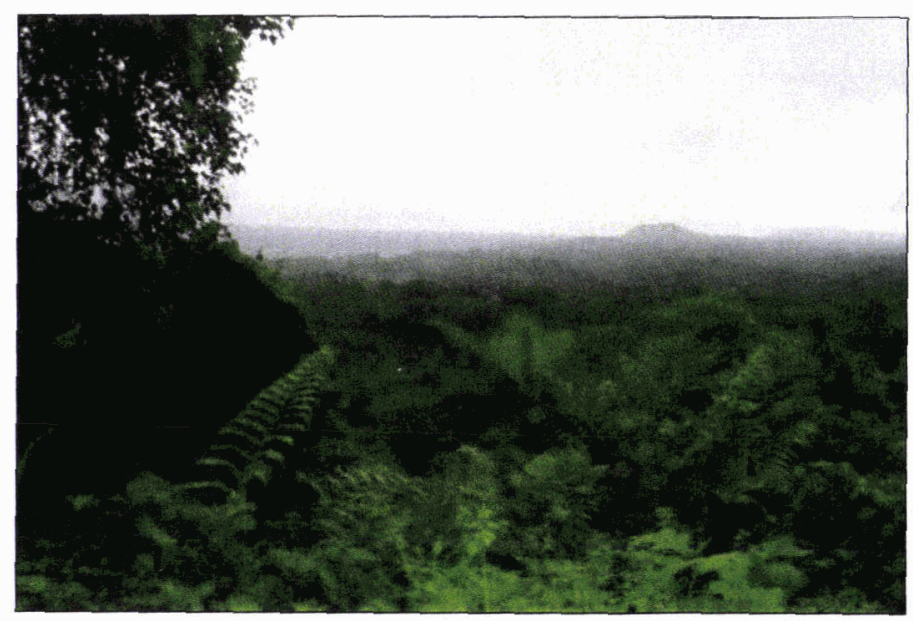

Source: Photo taken by Sarah Brikke 


\section{b) Evolution of women's perception of their forest resources (Monxhill)}

Table 7: Evolution of women's perception of their forest resources (Monxhill)

\section{PAST ("bifo")}

"The forest was a place where

you would get kastom

medicine, clothing and

weapons. "

"Hunting for meat."

"Gathering building material."

"No gardens, seasonal

gathering of fruits."

\section{PRESENT ("tede")}

"The hospital has the

medicine."

"Buy meat from the store."

"Same as past building."

"Divide the lands for the gardens for private supply and to sell at the market."

\section{FUTURE ("fiuja")}

"Forget about kastom medicine."

\footnotetext{
"There wasn't any logging. "Logging is starting. People "No big trees and no small There were a lot of big trees." clear the land for gardens." trees."
}

According to the women's perception of Monxhill on the evolution of their forest resources in their community (table 7), in the past, forests were places where people would get their "kastom medecine, clothing, weapons, meat (by hunting), and their building materials." The impact of humans on nature was very low, as they weren't any gardens (people would just gather the seasonal fruits) nor any logging."

Unfortunately, with time, the situation has changed drastically. People now do not use as much kastom medicine as before because they go to the hospital to get treatment and medicine. The meat is no longer hunted but bought is a shop. The lands have been logged, cleared and divided into gardens, for private supply and to sell the crops in the market. 
The women of Monxhill believe that in the future, the members of their community will "forget about kastom medicine and that they will buy meat from the big store." The relationship with nature will therefore not be as intense and daily as in the past. Moreover, no more lands will be available for the gardens and "there will be no more big and small trees", due to intense logging operations that will destroy the whole forest and lives present in the forest. There will therefore be no more natural food such as fruits or animals, no more building materials ("natangora" used to build the roofs), no more available lands for cash-cropping in the gardens, and no more trees. 


\section{c) Evolution of women's perception of their forest resources (Butmas)}

Table 8: Evolution of women's perception of their forest resources (Butmas)

\begin{tabular}{|c|c|c|}
\hline PAST ("bifo") & PRESENT ("tede") & FUTURE ("fiuja") \\
\hline $\begin{array}{l}\text { "Hunting wild pigs, birds and } \\
\text { fruit bats." }\end{array}$ & $\begin{array}{l}\text { "Hunting wild pigs, birds } \\
\text { and fruit bats." }\end{array}$ & $\begin{array}{l}\text { "If we look good after the } \\
\text { forest, we will be able to } \\
\text { continue hunting this way." }\end{array}$ \\
\hline $\begin{array}{l}\text { "Burn the bush to get access to } \\
\text { big trees." }\end{array}$ & $\begin{array}{l}\text { "Burn small trees to get to } \\
\text { large trees." }\end{array}$ & $\begin{array}{l}\text { "Burn grass to cut down big } \\
\text { trees in dark bush." }\end{array}$ \\
\hline $\begin{array}{l}\text { "When someone dies, the } \\
\text { family used to move to another } \\
\text { place." }\end{array}$ & $\begin{array}{l}\text { "Now, because of church, } \\
\text { chiefs and school, families } \\
\text { do not move anymore when } \\
\text { someone dies." }\end{array}$ & "Overpopulation." \\
\hline "Take custom medicine." & $\begin{array}{l}\text { "Some people still go to the } \\
\text { bush to get custom medicine } \\
\text { some go to the clinic and } \\
\text { some pray." }\end{array}$ & $\begin{array}{l}\text { "Old people still go to the } \\
\text { bush for medicine, pray } \\
\text { and/or go to the } \\
\text { dispensary." }\end{array}$ \\
\hline "Take vines for building." & "Use new material to build." & $\begin{array}{l}\text { "No more building products } \\
\text { in the forests." }\end{array}$ \\
\hline $\begin{array}{l}\text { "Get clean water for drinking } \\
\text { from the river." }\end{array}$ & "Some rivers are dry now." & $\begin{array}{l}\text { "Everything will be dry, } \\
\text { there will be no more fishes } \\
\text { in the rivers." }\end{array}$ \\
\hline $\begin{array}{l}\text { "It was free to sleep in the bush } \\
\text { and there were no mosquitoes." }\end{array}$ & $\begin{array}{l}\text { "Now, people don't sleep } \\
\text { anymore in the bush. You } \\
\text { need to have a mosquito } \\
\text { net." }\end{array}$ & "More mosquitoes." \\
\hline
\end{tabular}

According to the women's perception of Butmas on the evolution of the forest resources in their community (table 8), "if we look good after the forest, we will be able to continue hunting ... wild pigs, birds and fruit bats as they did in the past and now in the present". 
These people are aware of that by not protecting, conserving and taking care of the forest, there will be a series of negative consequences in the future, such as the death of animals (lost of nutritional source), no more building materials and no more custom (medicinal) plants to heal the people. Moreover, there will be a drought of the river (no more water to drink from the river), if nothing is done now, "everything will be dry, there will be no more fishes in the rivers."

After having identified women's perception (mental image of the forest), we will now explore how those women represent on a paper their perceptions, through the exercise of community resource mapping.

\subsection{Community resource mapping}

Thanks to the results and analysis of the community resource mapping exercise, the first objective of this research has been attained, which was to identify women's perceptions of their forest resources in Monxhill and Butmas.

\section{a) An introduction to the methodology}

The community resource mapping (appendix 4) is a methodology designed to get participants to visually represent an area as they see it. Mapping may not necessarily be about accuracy as it is based on perception.

Mapping can serve also to highlight group dynamics and perceptions as people discuss the way they see an area. Drawing on the map encourages people to think more about a particular issue and offers another way of expressing their views visually. 


\section{Figure 12: Community resource mapping (Monxhill)}

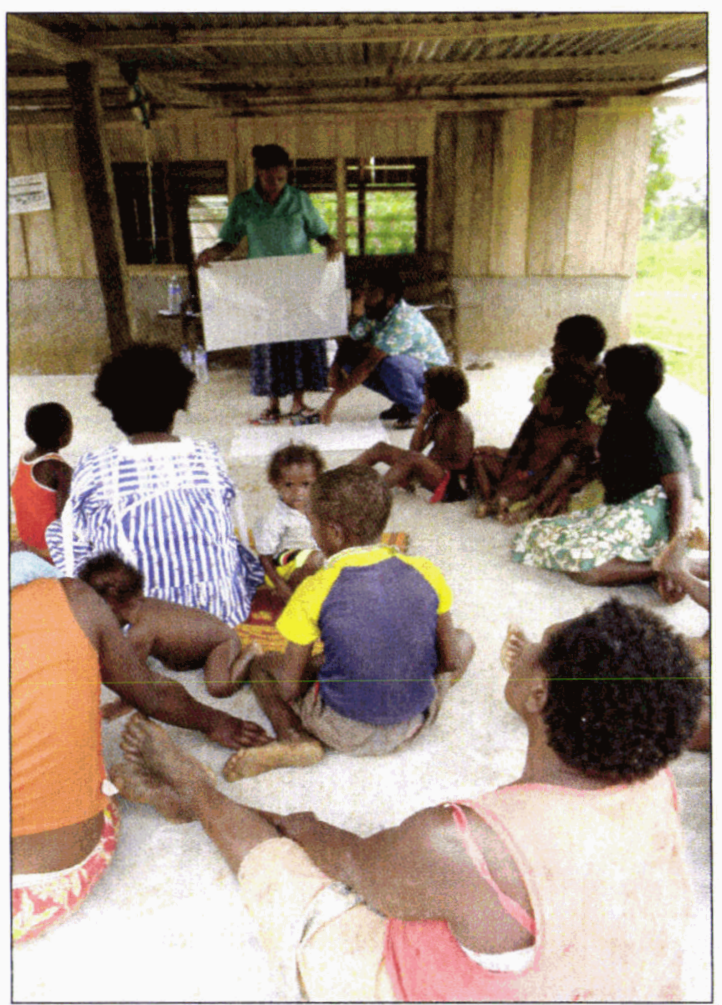

Source: Photo taken by Sarah Brikke

Community resource mapping can be used to promote increased thought and discussion on issues and help to gain several layers of information in a very useable format.

The objectives of this activity are to allow the participants to draw their visual representation of the forest and to have an improved understanding of forestry issues in their community.

The participants were divided into three groups and each group was provided with a task card, some markers and butcher paper. Three different themes were given on the task cards such as, forest conservation, cash- cropping and logging and deforestation. Each task card had points that the participants had to place on their map. 


\section{b) Resource mapping on forest conservation}

Figure 13: Resource mapping on forest conservation (Monxhill)

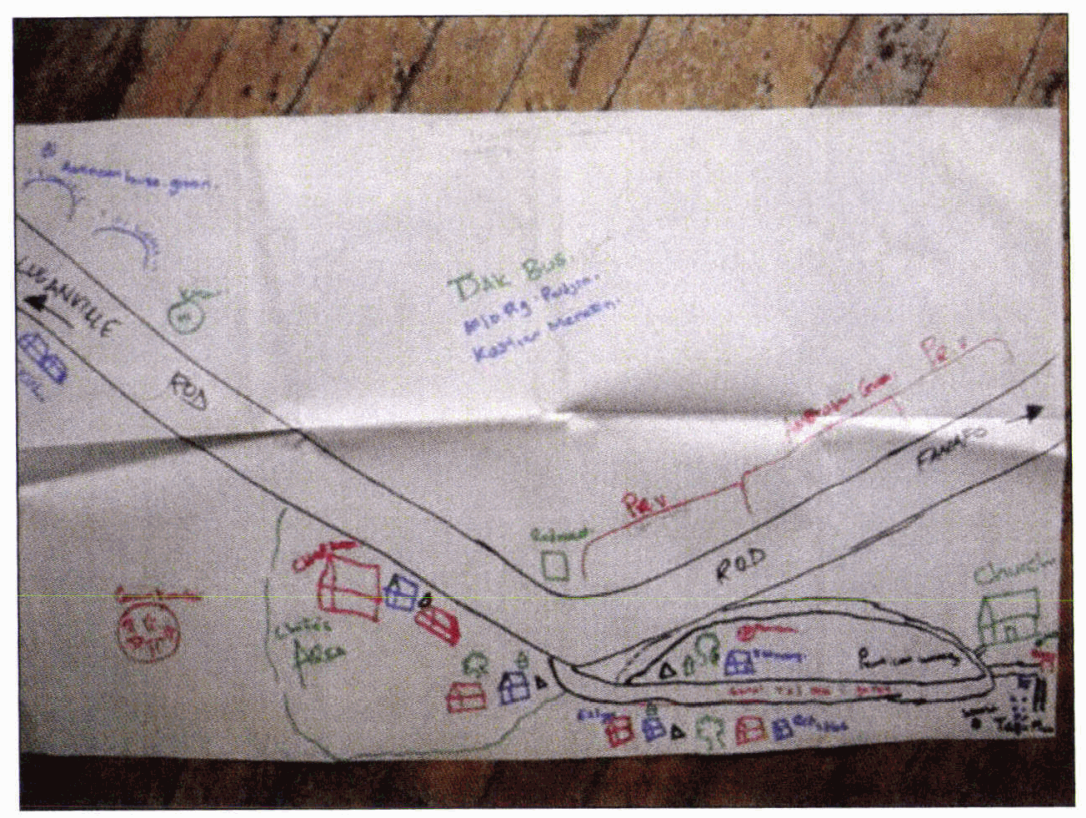

Source: Photo taken by Sarah Brikke

\section{Legend on the map:}

\section{Perception of forest conservation}

- Forests ("Dak bus")

- "Tabu", sacred places ("Tabu ples")

- Places where people go hunting or fishing ("Ples blo karem wild pig, faol, pidgin")

- Places where people gather medicinal plants ("Ples blo karem kastom meresin")

- Places where people go for recreation ("Ples go spel")

- Places valued for their scenery ("Ples blo turis I kam luk") 
Figure 14: Explanation of the 'forest conservation' resource mapping (Monxhill)

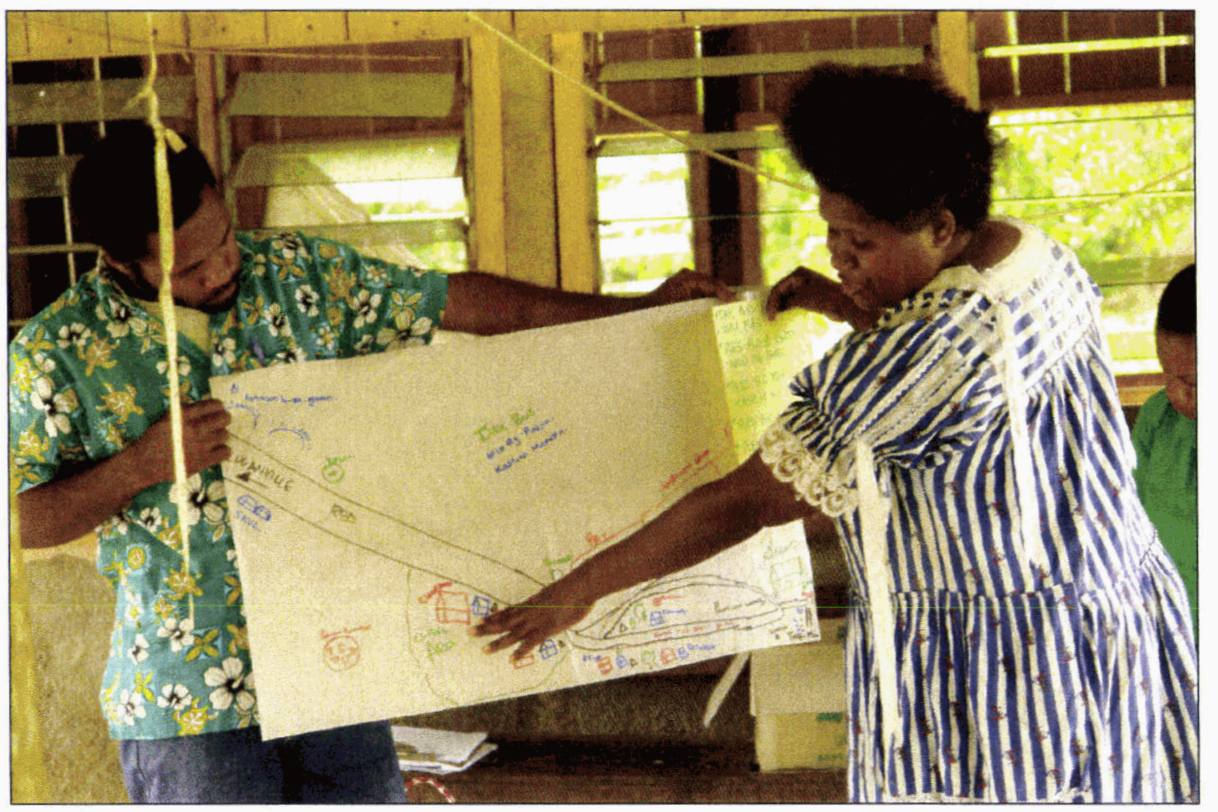

Source: Photo taken by Sarah Brikke

The map (Figure 13) on forest conservation shows us that the participants of Monxhill have a good knowledge of the localization of the forests ("dak bus" which seems to be just across the road of the community) and its nutritional and medicinal resources.

The forest seems to be close from their community, and is characterized as a place where people go hunting or fishing ("Ples blo karem wild pig, faol, pidgin") and as a place where people gather medicinal plants ("Ples blo karem kastom meresin"). 
c) Resource mapping on cash-cropping

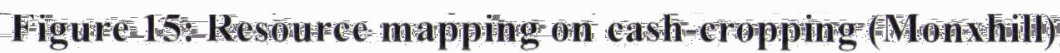

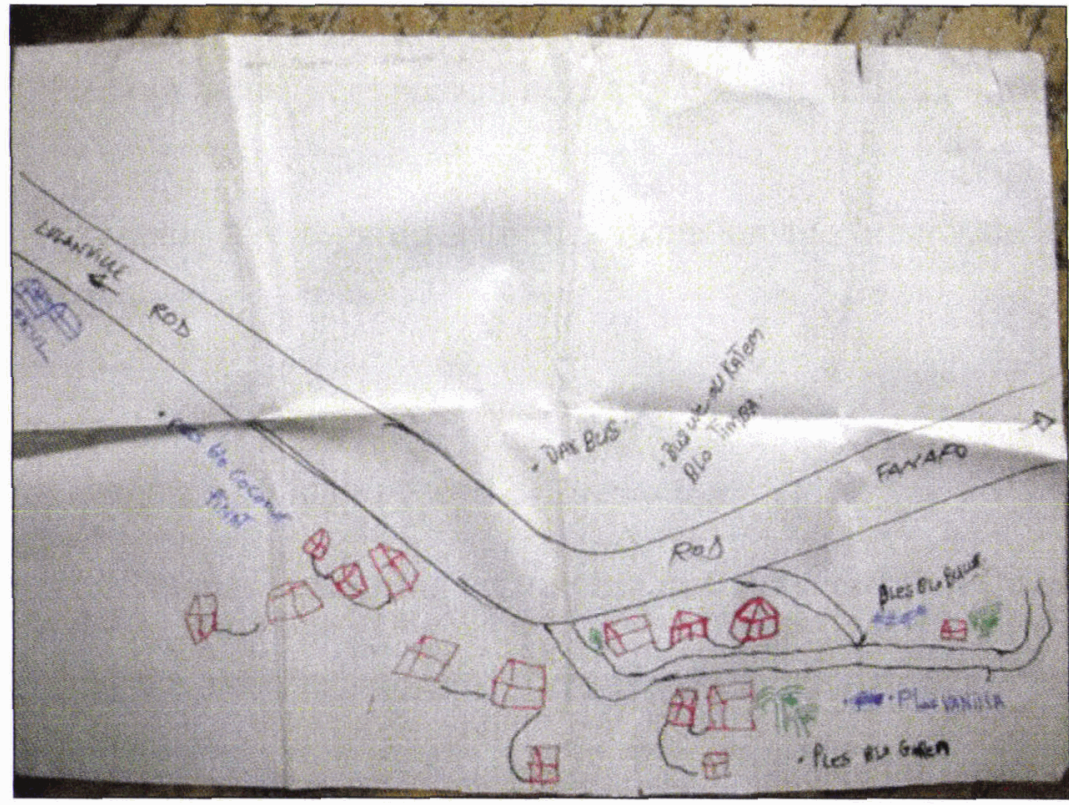

Source: Photo taken by Sarah Brikke

\section{Legend on the map:}

\section{Perception of cash cropping}

- Forests ("Dak bus")

- Forests that have been logged / will be logged ("Ples we oli katem blo timba")

- Land with cattle ("Ples blo buluk")

- Land cleared for gardening ("Ples blo garden")

- Land with agricultural activities: kava, peanut ("Ples blo kava, pinat")

- Proposed land for oil palm ("Ples blo oil palm")

- Proposed land for cash cropping ("Ples blo planem kakae blo maket")

The map (Figure 15) on cash-cropping describes well the different activities and human impacts that the members of Monxhill community have on their close environment. 
We can observe three types of antropic activities, which all have an impact on the environment.

Agricultural activities such as coconut, vanilla and peanuts plantations ("Ples blo kokonus, vanilla mo pinat) and gardening ("Ples blo garden) as well as cattle activities ("Ples blo buluk") are present next to the house of the community.

Finally, it seems that logging activities occur on the other side of the road where the "dak bus" is.

\section{d) Resource mapping on logging and deforestation}

Figure 16: Resource mapping on logging and deforestation (Monxhill)

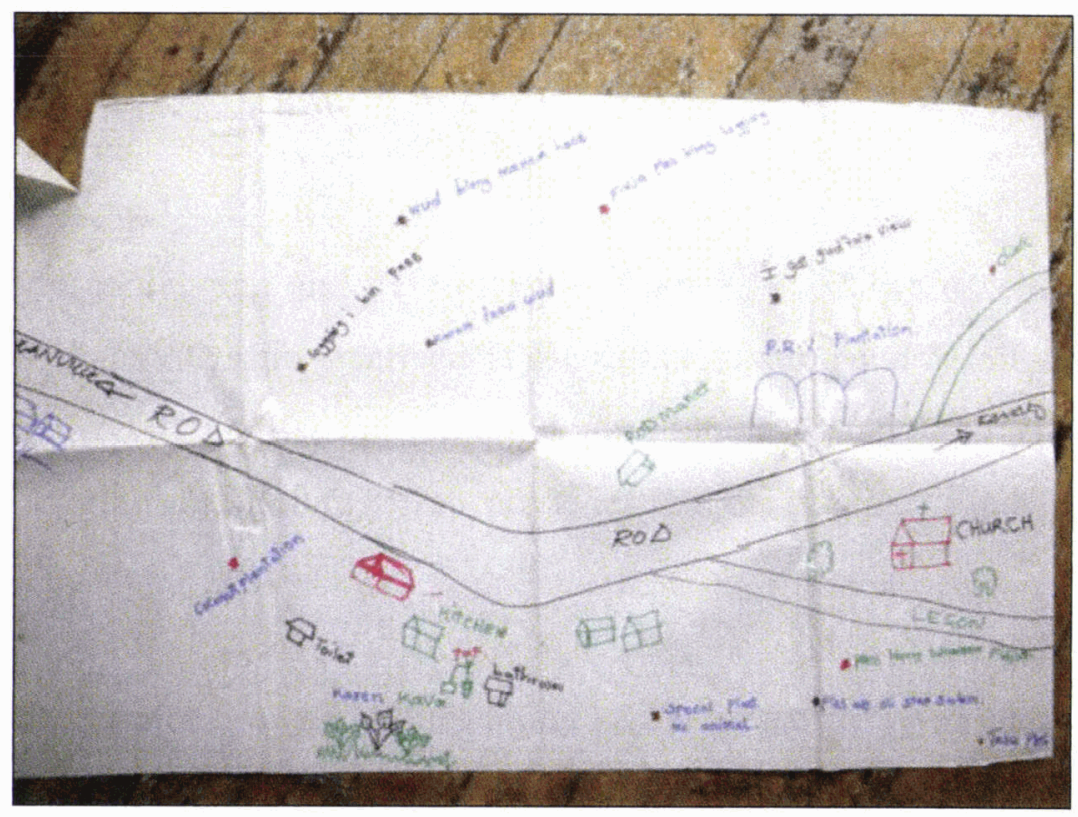

Source: Photo taken by Sarah Brikke 


\section{Legend on the map:}

\section{Perception of logging and deforestation}

- "Tabu", sacred places ("Ol tabu ples")

- Places where people go hunting ("Ples blong lukaotem pidgin")

- Place were they collect medicinal plants ("Ples blong karem ol meresin")

- Places where they collect firewood ("Ples blong karem faea wud")

- Places where they collect/cut trees for traditional houses ("Ples blong kolektem/katem wud blong mekem haus")

- Places with unique plants or animals ("Ples blong spesel plants mo animals")

- Places valued for their scenery ("Ples I gat gudfala viu")

- Possible sites for future logging activities ("Fiuja ples blong logging")

- Current deforestation sites: gardening, clearing for coconut plantations, clearing for new infrastructure ("Ples blong garen, coconas")

- Places where it cleared for selling purposes - for building houses, hotels, wharf, etc ("Ples we oli stap salem")

The map on logging and deforestation (Figure 16) shows us clearly where those types of activities are practiced. It seems that logging and deforestation were already practiced in the past, "ples blong login I bin pass" and that there are some plans for logging and deforestation activities for the future, "Fiuja ples blong logging".

The collection of firewood ("Ples blong karem faea wud") was usually used to build their traditional houses ("Ples blong kolektem/katem wud blong mekem haus").

Finally, it seems that amongst all these areas dedicated to logging and deforestation some "Tabu", sacred places ("Ol tabu ples") remain, which is a symbol of a traditional respect for the environment. 


\section{e) Resource mapping (Butmas)}

\section{Figure 17: Resource mapping (Butmas)}

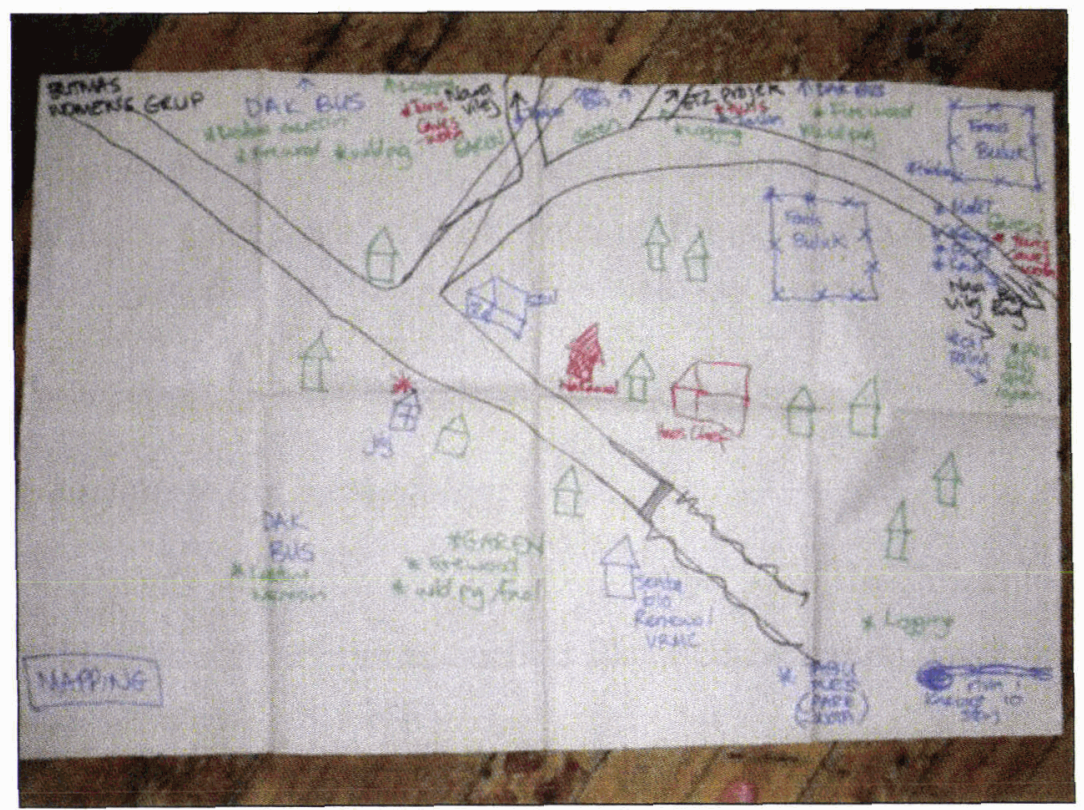

Source: Photo taken by Sarah Brikke

Concerning the case of the community resource mapping in Butmas (Figure 17 ), in order to make it simple for the community members, only one map was done.

We can observe on this map an important number of logging areas ("ples blong logging"), areas where the land has been cleared for gardening ("Ples blo garden") and places where they collect firewood ("Ples blong karem faea wud")

Moreover, it is clear on the map that there are two big places dedicated to land with cattle ("Ples blo buluk") and several areas where they raise pigs ("wild pig"). These two places must be one of the food resources for the community of Butmas.

According to the women leaders and women youth group of Butmas, there are several solutions to the negative impacts of logging such as replanting trees, the 
development of better policies for logging, making laws that ban logging, preserving forest for wildlife and finding alternative income to oil palm.

\subsection{Women's perception of influential actors on forestry issues}

Thanks to the activity of forms of power (see appendix 8), we were able to identify women's perception of their role in forestry issues in Monxihll and Butmas.

\section{a) An introduction to the methodology}

The participants were asked to determine who were the influential actors in decision-making on forestry issues such as forest conservation, cash-cropping and deforestation and logging.

This following list contains the influential actors on forestry issues, according to the women leaders and women youth group of Monxhill: Sanma council of women, chiefs, rural water supply, Youth, water committee, school committee, church, World Vision, Province, government, MP, UNELCO, VANWODS, Forestry Department and Agriculture Department. 


\section{b) Women's perception of influential actors on forest conservation}

Figure 18: The influential actors on forest conservation (Monxhill)

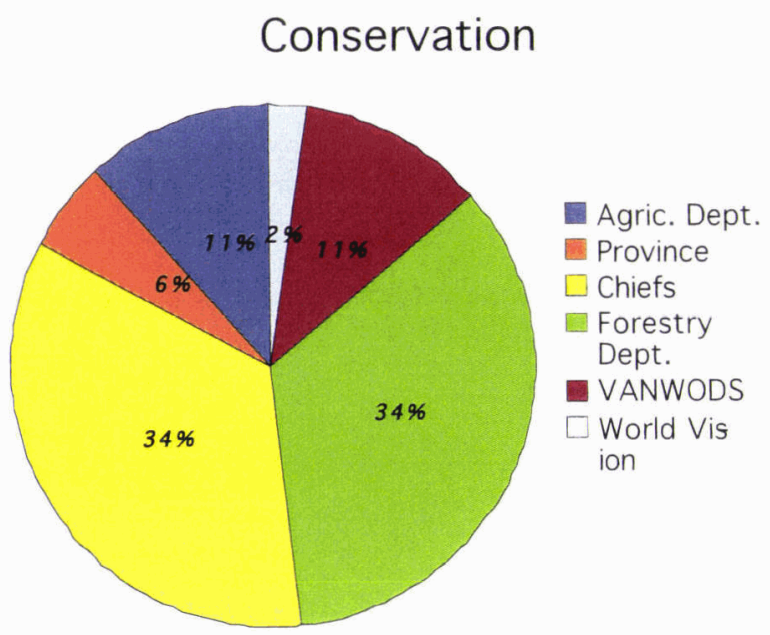

Chiefs (34\%) and the Forestry Department (34\%) seem to be the most influential actors on forest conservation issues, according to women's perception of Monxhill. (Figure 18)

The Agriculture Department (11\%) and VANWODS (11\%) have a moderate influence, contrary to the Province $(6 \%)$ and World Vision $(2 \%)$ who have a small influence on forest conservation issues.

These results show well the important role that chiefs have in their community. They are the ones who have the power in decision-making concerning all the issues and concerns present in their community. It is therefore necessary to make them aware of the benefits of forest conservation and protection. 
c) Women's perception of influential actors on cash-cropping

Figure 19: The influential actors on cash cropping (Monxhill)

\section{Deforestation}

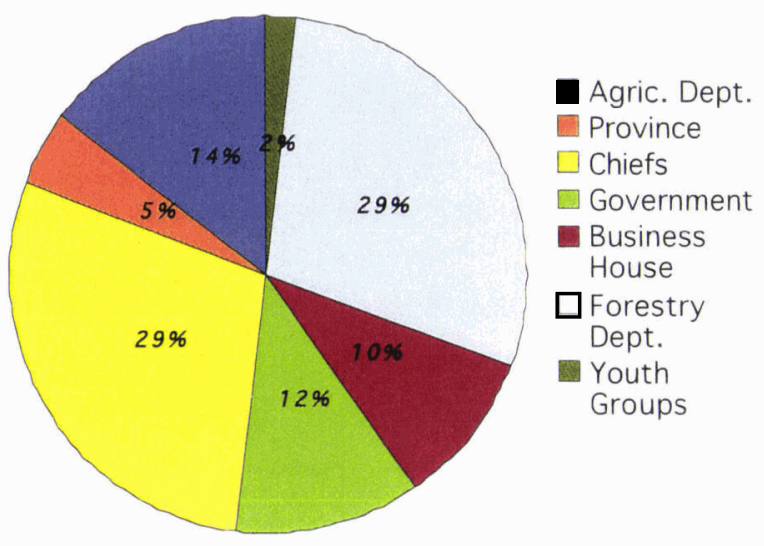

Once again, chiefs (29\%) and the Forestry Department (29\%) seem to be the most influential actors in cash-cropping issues, according to women's perception of Monxhill.

Agriculture Department (14\%), Government (12\%), Business House (10\%) have a moderate influence, whereas the Province (5\%) and Youth Groups (2\%) have a small influence. (Figure 19) 


\section{d) Women's perception of influential actors on deforestation and logging}

\section{Figure 20: The influential actors on deforestation and logging (Monxhill)}

Deforestation

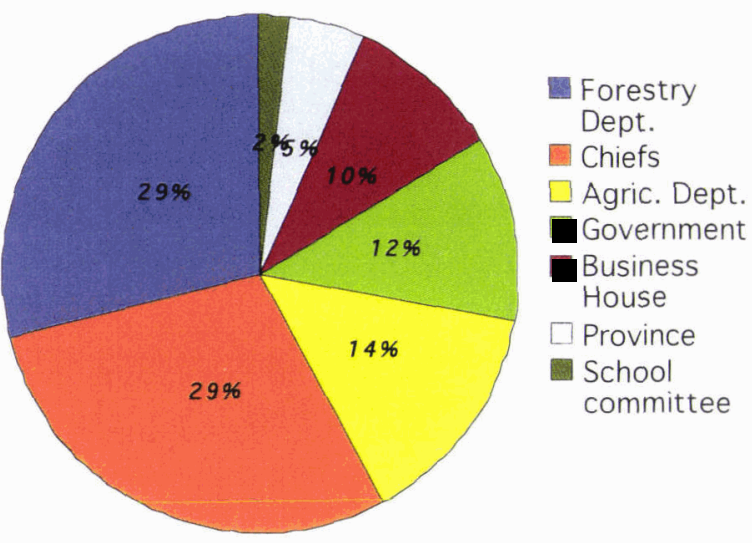

The most influential actors on deforestation and logging issues are the Forestry Department (29\%) and the chiefs (29\%). The Agriculture Department $(14 \%)$, the Government (12\%) and the Business House $(10 \%)$ have a moderate influential power, whereas the Province (5\%) and the school committee $(2 \%)$ have a small influence on deforestation and logging issues. (Figure 20)

To conclude, chiefs and the Forestry Department have a strong influence on decision-making on issues such as forest conservation, cash-cropping and deforestation and logging.

Therefore, it is essential, on a community level to make chiefs more aware of the harmful consequences of deforestation, logging, oil palm plantations and bad management of the environment. Women do not seem to have influence on decision-making. 


\section{DISCUSSION}

\subsection{About women's perceptions of their forest resources (objective 1)}

Traditionally, an intimate relationship exists between people and their natural environment in the South Pacific. The land and the sea are not only vital for subsistence and exchange, but also form the basis for kinship systems and spiritual values.

More particularly, concerning the relationship between women and the forest, the research revealed that the majority of the participants of Monxhill perceived the forest as being "a place to live, to know and to learn about, to plan for and take care of. The village and garden is my environment." Whereas, the majority of the participants of Butmas, perceived the forest as being "a resource: it is to be managed so that it can provide us with food, materials and medicines"; the women of Butmas believe that the "forest is a problem, which has to be solved, we need to fix up pollution, and over harvesting of our fish and forests."

Deforestation and forest degradation is a growing issue in Vanuatu. There are three principle reasons that this occurs: logging, cattle farming and subsistence agriculture. As we can see on the following map, the loss of forest area has been over 801 ha between 1990 and 2000 on the island of Espiritu Santo. (Weaver, 2007).(Figgure 21). 
Figure 21: Loss of forest area 1990-2000 observed from the satellite data for different islands of Vanuatu

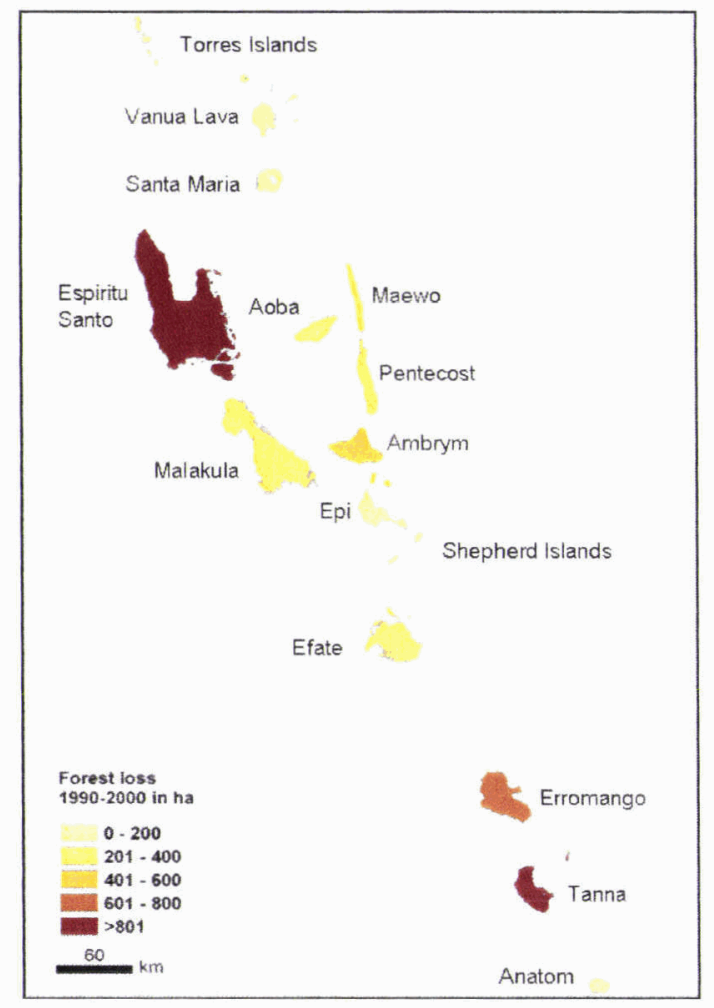

Source: Weaver, 2007

\subsection{About women's perceptions of their needs and concerns (objective 2)}

In many rural areas the local level drivers of deforestation are closely linked to community development needs. Economic pressures faced by individuals and their families contribute to over harvesting of resources, breaking natural resource management taboos and poaching protected resources. (Weaver et al, 2007).

Women knew about all the needs and concerns of their community. They understood that education, health and participation are main priorities for the wellbeing of their families and communities. But they were caught between two dilemmas: on the one hand, the most important needs and concerns were related to water, sanitation and health, while they realized on the other hand, the need for greater participation, empowerment and education.

However, the research has helped to highlight the following main points that affect women's life and decision-making:

- Problems related to health and to financial issues 
- Lack of education and communication in the community

- Many women raise their children alone

- Some of the women suffer from domestic violence

- Water supply and sanitation is not adequate

The research showed that women leaders and women youth group of the Monxhill community shared their will to have a Women Centre for them, to be able to meet amongst women and to form a group in order to be present in decision making processes. It also showed the important role that chiefs have in the communities of Monxhill and Butmas. They have the power in decisionmaking concerning all community matters as well as forestry decisions such as forest conservation, cash-cropping, logging and deforestation. It is therefore necessary to make them aware of the benefits of forest conservation and protection and further research is needed to better address their role in environmental awareness and education.

Through participatory education processes, women can become active agents of change in their community. The learning methodologies and practices need to foster environmental action and make sure that they are inclusive and sensitive to gender. Feminist education methodologies aim at empowering those with little or no power and enabling people to see that they do have the power to work towards social and ecological change.

By learning how to earn money other than by selling crops, those women could earn more money and therefore be more independent financially from their husbands. And usually when a woman has money, she will not spend it on kava or beer, but on the education and better nutrition of her children. Women's education is therefore a key to sustainability and wellbeing of the community. Paulo Freire stated a very interesting idea: "To know how to teach is to create possibilities for the construction of knowledge rather than being engaged simply in a game of transferring of knowledge". Indeed, the community is an appropriate place to bring education, to learn, to take decisions, to solve problems, to share information, and to educate people how to participate more in decision-making processes. One of the main concerns of environmental education is to heighten the awareness of local communities on development and conservation issues, in order 
to understand better the role and impacts of human on nature and to be able to find the best solutions to have a healthy environment, for us and the future generations.

\subsection{About women's perceptions of their role in forestry issues (objective 3)}

The most influential actors on forest conservation issues and on logging and deforestation, according to the women leaders and women youth group of the Monxhill, were the chiefs and the Forestry Department. The chiefs had an essential role in decision-making for issues related to their community.

However, according to the Constitution of 1980: "anything on the land, is owned by local landowners or chiefs". The chiefs want the "kastom" to be promoted in and inserted in the Constitution. Women do not have their say in decision- making, in activities of the communities as for example in forest conservation projects. In the traditional "kastom", women have to show respect to men.

According to women leaders and women youth group of the Butmas community, there were several solutions to the negative impacts of logging such as replanting trees, the development of better policies for logging, making laws that ban logging, preserving forest for wildlife and finding alternative income to oil palm.

According to the women, in the past, forests were places where people would get their "kastom medecine, clothing, weapons, meat (by hunting), and their building materials." But, the problem of deforestation and pollution wasn't known or wasn't considered as important for them.

Just as human beings struggle for space, time, and care in order to grow individually within supportive non-controlling relationships, so we must give non- 
humans and nature space, time, and care allowing them to reproduce, evolve, and respond to human actions. In practice, this could mean not cutting forests or damming rivers that force people and wildlife to become more vulnerable. Conceptualizing nature as a partner, rather than a force or something wild to be tamed, allows for possibility of a personal or intimate relationship to develop (Wane and Chandler, 2002, p.96).

Although most of those women haven't been to secondary school or haven't had any formal education their knowledge on nature is vast and rich. A recommendation could be to put money into coconut replanting and rehabilitation of existing plantations. 


\section{CONCLUSION}

"Humans have a lot of necessities and to satisfy a great part of them, they take advantage of the elements that the environment offers, who, at their turn, become resources. In this process humans transform themselves in builders of their space: they can change the climate, change the waterway, modify the landscape, transform the desert into a productive fertile soil. Everything depends greatly on the relations established between humans and their environment, on their perceptions, their feelings and their knowledge, which at the same time orients their actions." (Bernex, 2004).

The conservation of environmental resources has become an essential global challenge for the $21^{\text {st }}$ century. Unfortunately, forests are gradually disappearing for various reasons such as, logging, deforestation, and oil palm planting. There is therefore an increasing appeal to more ecological consciousness, which calls for a change of behaviour and the rediscovery of the relationship between humans and their environment.

The role of women as 'ambassadors of the environment' for their island and their community is of great importance. How participating and empowered women can have an impact of forestry issues, depends on their perceptions, feelings and knowledge, as this will direct their actions.

Therefore, the aim of this research has been to investigate in two communities of the island of Espiritu Santo of Vanuatu (Monxhill and Butmas), the perception of women on their forest resources and to see to what extend an increase in women's participation and empowerment can improve and enhance forest conservation outcomes in Espiritu Santo.

To achieve this aim, the following three objectives of this research were pursued and revealed the findings synthesized in chapter 7 . 
1. Identify women's perceptions of the forest in Monxhill and Butmas;

2. Identify women's perceptions of their needs and concerns related to development aspirations in the communities of Monxhill and Butmas;

3. Identify women's perceptions of their role in forestry issues in Monxhill and Butmas.

The remained of the chapter will put this research and it sfindings into the context of women's NGO in Vanuatu and the global challenges of climate change and deforestation.

Throughout generations, local communities of Vanuatu have developed an intimate relationship and awareness of their local environment, which has also guided their beliefs and livelihoods. They have therefore generated knowledge on how to deal and live with their environment. However, ecological degradation and inappropriate management of natural resources are still prevalent, which threatens these relationships, livelihoods and knowledge systems.

Unfortunately, "women are seldom found in level of decision-making in the vast majority of government offices, institutions, NGOs and sometimes, even at the village level ... By facilitating a dialogue between men and women, as happens in 'Pacific Star', actors can demonstrate the necessity of listening to the ideas of women if development is to be life-centered, just and fulfilling for all."(Fien and Passingham, 2002, p.67).

The purpose of environmental education is to teach people about their environment and its resources, and to explain why good management and conservation practices are necessary. At the same time, environmental education must learn and draw from the knowledge of indigenous people, which has always guided their sustainable resource use. As Paolo Freire proposes, let education be a sort of conversation process in the empowerment of communities, which will encourage local responsibility and therefore the sustainability of development. 
In Vanuatu, several women's NGOs and associations, such as the National Council of Women and the Women's Centre, play an important role in educating the public and have been actively involved in the search for women's well-being and respect.

Moreover, other NGOs such as VANWODS (Vanuatu Women's Development Scheme) focused more particularly on the promotion of micro-finances in communities, in order for women to be involved in business. The objectives of their program are to provide accessible financial and business development services to economically marginalized individuals and communities in Vanuatu. VANWODS started as a pilot project implemented under the then Department of Women and culture in 1996 with financial and technical support from the United Nations Development Program - UN Office for Project Services (UNDP-UNOPS) Regional Equitable and Sustainable Human Development Project. The Project was initiated in response to the Vanuatu National Plan of Action for Women to provide disadvantaged women with access to microfinance and income earning opportunities.

In general, a lack of understanding of the complexities of deforestation and climate change and a limited input from local forestry experts have hampered 
authorities need to have more respect and resources to effectively enforce existing regulations and monitor compliance. In terms of forest management, it is also important to make a classification of forest sites that need to be protected urgently.

However, the solution to increased deforestation could go beyond such regulations and address environmental awareness and education of the involved communities, involving local communities in all programs of management, conservation and education of the public. 


\section{APPENDICES}

Appendix 1: Age and level of education (Monxhill)

\begin{tabular}{lll} 
& LEVEL OF & NUMBER OF \\
34 & EDUCATION & CHILDREN \\
33 & Primary & 4 \\
38 & Primary & 3 \\
22 & No & 4 \\
20 & Primary & 4 \\
24 & Secondary & 2 \\
18 & No & 0 \\
75 & No & 1 \\
20 & No & 7 \\
48 & Primary & 4 \\
46 & Primary & 4 \\
25 & Primary & 4 \\
11 & Secondary & 4 \\
17 & Primary & 0 \\
\hline & Primary & 0
\end{tabular}




$\begin{array}{lll}\text { Age } & \text { Level of education } & \text { Number of children } \\ \text { Doesn't } & \text { Class } 3 & 4 \\ \text { know } & \text { Year } 7 & 3 \\ 25 & \text { None } & 8 \\ \text { Doesn't } & & \\ \text { know } & \text { Class 6 } & 1 \\ 22 & \text { Year 7 } & 2 \\ 24 & \text { Class 6 } & 4 \\ 33 & \text { None } & 5 \\ 52 & \text { none } & 6 \\ 55 & \text { Secondary } & 4 \\ 32 & & \end{array}$

\section{Appendix 3: Guidelines for the Facilitator}

When commencing work with the community explain why you are doing the RAP and what it will be used for. People's time is precious, be well prepared and efficient. This also shows respect to the participants. Often research benefits an organization, a government department or a donor and not necessarily the community. Explain from the outset how the RAP approach seeks to benefit the community. Focus on the use of participation to lead to practical and useful initiatives related to environmental management in the community (Live and Learn, 2006).

\section{Ten Important Guidelines}

To ensure we start from where people are at, and ensuring we address real community needs we always do a RAP before commencing work. Basically the RAP will inform and shape our approaches so it is important it is of high quality and comprehensive. Good facilitation will assist us in getting good data, so here are a few hints for the facilitators: 
- Be clear on what you expect from the participants and let them know how you will conduct the research (a simple outline) and ground rules for the research e.g. no interruption or domination.

- Be prepared and respect peoples' time. Make sure you are prepared and have all the materials ready.

- Do no attempt to note-take whilst facilitating. Note taking is a separate job.

- Use visual aids and examples where-ever possible (for example using a map).

- Do not pay for people to participate but explain how they will benefit from the RAP and the project.

- A group should not exceed 15 people.

- During discussion place people in a circle (on the floor, mat or chairs)

- Often strong characters will dominate the research process. If you have a strong character in the group direct your focus on the quiet persons and allow for their participation. It is acceptable to conduct research according to age, race and gender lines.

- Conflict and disagreement is okay as long as it is non-personal and directed at the issue at hand.

- Always keep the Research Questions in mind. They are your guide and the data collected needs to answer the questions.

Facilitation Skills

The following have been identified as important functions for a facilitator:

- Sustain or create interest and mobilize people

- Create a comfortable and open learning environment

- Understand and explore participants' problems and priorities

- Identify and organize learning opportunities for participants' outside their context

- Facilitate dialogue and participatory group decision-making to promote mutual understanding

- Build participants' confidence in experimenting, reflecting and learning from this process

- Provide assistance for solving problems 


\section{Appendix 4: Resource Mapping}

\section{Objectives}

Participants

- Can see a visual representation of and have an improved understanding of the environmental issues in their community

\section{Materials}

- Consider issue that are important in the context of their community

- Copied hand out -5 theme areas and short background to project, including contact details. It is important to clarify who we are and what we are doing in their community.

- Butchers paper \& marker pens - A basic map is drawn on the flipchart paper prior to the exercise including key reference points (Church, main road).

- Task cards for the mapping exercise (appendices \#1)

- Camera and /or video camera to document activity.

\section{Time}

Approximately 40 minutes

\section{What to do}

- Introduce the session by saying that this approach is designed to gain as much participation from them as possible. Give an overview of the 5 themes and general project approach (handout). We are not donors like Red Cross, we are here to support activities through environmental education. Also emphasise the benefits from the process.

- Place the butchers* paper, with an outline map of the community / region including key reference points. This needs to be in a suitable location for all people to see it and be able to place information on it.

- Start the process by getting more detail on the map - ask about the location of houses, school, churches, medical centre, etc. Then get the participants to each place their house on the map.

- Divide the participants into three groups and provide each group with a task card and some markers (a different colour for each group). There will be task cards for 3 different themes:

(i) Environment and health

(ii) Environment and making a living

(iii) Environment and culture

Each task card will have questions / ideas for places or events to mark on the map. Ask each group to discuss these and to draw them on the map - they may use a map 'legend' if necessary.

- Allow 20 minutes for mapping. When the map is complete ask each group to explain what they have drawn on the map to the other participants. Ask if anyone would like to add or change anything to the map after each presentation. 


\section{Appendix 5: Focus Group discussions}

\section{Objectives}

Participants...

- Identify important needs and concerns in the context of their community

- Critically discuss why various needs and concerns are important in the context of their community

\section{Materials}

- Butchers paper \& marker pens - ruled up with headings as shown below

- Camera and /or video camera to document activity.

\section{Time}

Approximately 40 minutes

\section{What to do}

Ask the participants to remain in the same 3 groups as earlier (change the groups only if it's necessary for better group dynamics).

Provide each group with a large piece of butchers paper ruled up as follows:

Needs and concerns Why?

In Bislama this translates as follows:

Ol samting we yu tink se komuniti From wanem?

i nidim, o i save makem problem

Ask each group to reflect back on the mapping exercise, this is vital so that a range of issues (for example associated with land use) can be considered in this exercise. Each group will have a different focus:

- 'Needs and concerns' associated with water, waste or health

- 'Needs and concerns' associated with making a living from the environment

- 'Needs and concerns' associated with culture

Allow each group at leat 20 minutes to discus and produce a list. Then ask each group to present their table to the rest of the group. Allow other participants the opportunity to comment on each issue, and add new issues if necessary. 


\section{Appendix 6: Ranking}

\section{Objectives}

Participants...

- Critically examine needs and concerns of the community

- Rank the needs and concerns of the community from most to least important

\section{Materials}

- Issues written on strips of paper (3 sets)

- Stapler

- Camera and /or video camera to document activity

\section{Time}

Approximately 40 minutes

\section{What to do}

Develop one list of 'needs and concerns' from the lists generated from the previous activity (if some issues are repeated more than once, collate them into a single issue). Ask the participants to go back to their groups. Provide each group with the issues written on strips of paper and ask them to rank the issues (put them in order) from most to least important according to their opinion.

When the groups have completed the task (and have reached a consensus) ask them to present their ranking to the other groups. They must also provide a rationale or reason for their ranking. If there are too many needs and concerns to rank (e.g. more than 10), then just ask the group to present a rationale for their top 4 or 5.

Allow the other groups the opportunity to ask questions to the group presenting their ranking. Then allow each group to reconsider their own ranking. The activity concludes when all groups have presented their rankings and have had time to discuss and reconsider their rankings based on the dialogue. Ask each group to staple their final rankings onto a piece of A4 paper and collect then for future records.

\section{Lessons learned from previous RAPs:}

It is important to stress to the participants that there is no right or wrong answer. Some groups hesitate to do the ranking in case they get it wrong. There is no wrong answer-just the perceptions of the participants!

Be aware that participants are to have an open minded dialogue or conversation about the reasons for their ranking. This is an activity that can easily turn into a debate where one group tries to beat another. Encourage each group to consider changing their rankings based on reasons from other groups - praise this as a positive thing.

As a facilitator, ask questions but be careful not to give your own opinion. 
Appendix 7: How do you see the environment?

\section{Objectives}

At the end of the session the participants...

- Can identify the ways in which they perceive and value the environment

- Consider the that people perceive and value the environment in different ways

\section{Materials}

- Posters containing descriptions of different ways that people perceive the environment (appendices \#2)

Time

Approximately 20 minutes

\section{What to do}

Place the 6 'environmental perceptions' posters in separate locations around the room. (See next page for details of the posters). Explain to participants that there are many different ways of perceiving and valuing the environment. Introduce each poster and explain what it means (with examples). Allow the participants to ask questions about the posters.

Ask each participant to think about which environmental discourse (poster) best describes the way that they perceive value or feel about the environment. Allow them to move around the room to explore the options and discuss this between themselves. Make sure that the participants understand that there is no correct answer to this task - just individual perceptions. They are likely to identify with more than one poster, however the task is to choose the one that they think fits them best.

When they have made a decision ask them to stand next to the poster that they have chosen. Ask for volunteers to explain to the group why they stood where they stood.

Record the number of people who have selected each environmental perception.

\section{Lessons learned from previous RAPs:}

"We asked participants to look at the posters during afternoon tea. This saved us (the facilitators) time, and also gave them plenty of time to consider their options and their own point of view."

"When we resumed the workshop we asked everyone to stand in the middle of the room with their eyes closed. We asked them to select the environmental perception poster that they felt best represented their view and then asked them to move to it on the count of three. This way they seemed to be less influenced by what other people had chosen."

Its also important to take participants level of reading ability into consideration. Make sure that all the options are read aloud, several times if necessessary. 


\section{Appendix 8: Forms of power}

\section{Objectives}

At the end of the session the participants...

- Consider who makes decisions about the most important environmental issues affecting the community

- Record the information to assist understanding of decisions making and influence in the community

\section{Materials}

- 2 x 'Ranking Influence' sheets per participant (see appendices \#3)

\section{Time}

Approximately 30 minutes

\section{What to do}

Explain the objectives of the activity. Choose 2 highly ranked issues from the previous activity. Provide each participant with 3 copies of the ranking issues sheets, and ask them to write one issue on each sheet.

Explain how to fill out the sheet by providing an example. Allow participants time to discuss the levels of influence between themselves and to fill out the sheets. Collect the sheets when everyone has finished filling them in.

The instructions on the sheet are as follows:

Plis kivim wan mark long ol grup ia.

1 - Less (smol) influence mo 5 - big influence

Eksampol, sapos yu kivim 5 mark iko long ol landowners, hemia i minim se ol landowners nao oli kat bigfala influence long taem blong mekem decision long wan issue we iko wetem graon. 


\section{Appendix 9: Semi-structured interview}

The interviews should be conducted on a one to one basis - individual., with women's Committee, Community Committee, Youth Clubs (sports etc), and School Headmaster. It is envisaged that there will be $7+$ interviews of women in each village. The focus of the interview is based on the participatory map.

Ask the women to have a look at the map and see what comments they have about the information. Before commencing the interview, review the 'tips for conducting an interview' on the following page. You should record detailed notes from the answers to the interview questions in a note book, clearly labelled with date, time, interviewer and interviewee.

\section{Questionnaire:}

- What positive environmental initiatives has the community been involved with?

- What are some of the difficulties getting things done in the community?

- What resources do you need to become more effective?

- Is the community active on any development activities? (Focus on the last year) What, where $\&$ when? Were people from the broader community involved?

- Which groups are most active in community projects?

- How can we get the community involved in environmental projects?

- Who do you communicate with about environmental issues (e.g. waste, water, forestry, eco-tourism)?

- What communication channels work well in the community?

- What level of dialogue do you have with Government authorities?

- What are the constraints to dialogue with the Government authorities? Has any NGO expressed interest in working with your community? When, why, how, what happened? 


\section{Tips for conducting the interview}

\section{Before you start}

A. Make sure that you introduce yourself properly if you don't know the person you are surveying, try to make them comfortable and build some rapport before starting

B. Clearly state the purpose of the survey and give a brief overview of the ESD project.

C. Explain that your conversation will be part of the RAP report

D. Tell the people how long the interview will take, and make sure that it is a convenient time

\section{Conducting the Interview}

- Begin with some friendly general conversation to help the people feel at ease

- Ask the questions in order and try to keep the conversation to the topic of the question

- Be cautious about asking "why" because it can make people feel like you are passing judgment on them

- Beware of asking the questions in a way that could influence the householder's answers. For example, never ask "Don't you think that ..."? This is called a leading question

- Be sure that you have clearly understood the answer. If not, ask the person to repeat the answer. Always ask the person to explain words and ideas that you do not fully understand. Do not assume that you know what the answer is because of your own knowledge and experience

- Avoid passing judgment, giving advice or your own opinion

- Avoid discussions that are not useful. Keep to the topic of the interview

\section{Closing the Survey}

E. Ask the person if there are any questions they would like to ask you

F. Discuss the next steps

G. Thank the participant for their time and trouble 


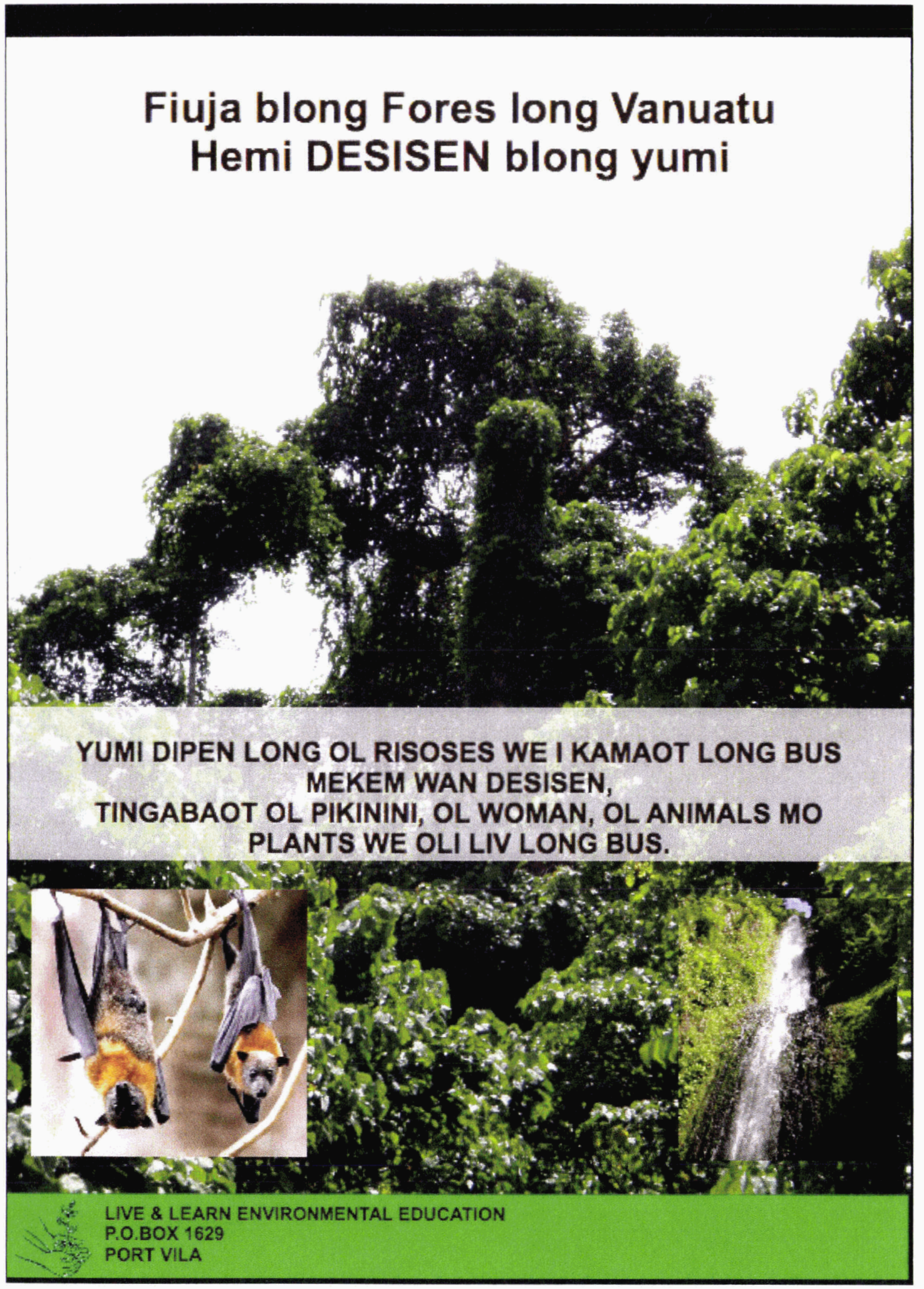




\section{Appendix 11: Bibliography}

Abram, D. (1996). The spell of the sensuous: Perception and language in a more-than-human world. New York: Vintage Books.

Ameyaw, S. (1992). "Sustainable development and the community: Lessons from the KASHA Project, Botswana", The Environmentalist, Vol.12, No.4, pp.267-275.

Ba N'Diaye, S. and Moussoulimou K. (1993). "Theory and practice of Feminist Popular Education". In Voices Rising No.1.

Bailly,A. (1974). "La perception des paysages urbains. Essai methodologique", L'espace geographique 3(3), Paris, pp.211-217.

Batibo, H.M. (2001). "The endangered languages of Africa: A case study from Botswana". In L.Maffi (Ed), On biocultural diversity, linking language, knowledge and the environment (pp. 311-324). Washington: Smithsonian Institute Press.

Batliwala, S. (1994). “The meaning of Women's Empowerment: new concepts from action”. In G,Sen, A. Germain and L.C. Chen (Eds) Population Politics Reconsidered: Health, Empowerment and Rights. Boston: Harvard University Press.

Bavoux, A. (1978). "L'environement, l'espace vecu a travers quelques ouvrages". L'espace geographique 7(4), Paris, pp.297-299.

Beneria, L. (1982). Women and development: the sexual division of labour in rural societies. Praeger: New York.

Berdoulay, V. (1974). "Remarque sur la geographie de la perception". L'espace geographique, 3(3), Paris, pp.187-188. 
Bernex, N. and Montenegro, J.L. (1997). Nosostros y los Andes - Ambiente y educacion.

Proyecto Educacion Ecologica en Formacion Magistral, Ministerio de Educacion, COSUDE, Tome I (209p), Tome II (529p).

Bernex, N. (2004). Amanecer en el Bajo Hutanay. Diagnostico de Recurosos Naturales Del Valle de Cusco, Lima, 551p.

Berque, A. (1978). "Probleme de population: ou s'arrete l'investigation du geographe?", L'espace geographique, 7(4), Paris, pp.67-68.

Bhasin, K. (1992). “Alternative and sustainable development". Convergence, XXV (2), pp. 26-36.

Boff, L. (1995). Cry of the earth, cry of the poor. New York: Orbis Books.

Bonnemaison, J. (1990-1991). Vivre dans l'ile. L'espace geographique (2), p.123.

Bouilding, K. (1956). The image. University of Michigan.

Bradshaw, M. and E. Stratford. (2005). Qualitative Research Design and Rigour. Qualitative research methods in human geography. I. Hay. South Melbourne, Vic. New York; Oxford University Press, pp. 67-76.

Brikke, F. (2000). Operation and maintenance of rural water supply and sanitation systems $-A$ training package for managers and planners. Operation and Maintenance Network of the Water Supply and sanitation Collaborative Council, IRC International Water and Sanitation Center, Delft, Netherlands. World Health Organization, Geneva, Switzerland, p.290.

Brikke, S. (2006). La perception des populations locales sur les tortues marines en Polynesie Francaise, cas de Bora Bora et Maupiti. Institut de Recherche Interdisciplinaire pour le Developpement Insulaire et le Pacifique et le Ministere du Developpement Durable Direction de l'Environnement. Papeete, Tahiti, 155p. 
Brookfield, S. (1987). "How critical thinking sustains a healthy democracy". In Brookfield, S. Developing critical Thinkers: Challenging Adults to Explore Alternative Ways of Thinking and Acting. Open University press, Milton Keynes, pp.51-68.

Brown, L. and Strega, S. (2005). Transgressive Possibilities. Research as resistance: critical, indigenous and anti-oppressive approaches. L. B. a. S. Strega. Toronto, Canadian Scholars' Press/Women's Press, pp.1-18.

Brunet, R. (1974). "Espace, perception et comportement". L'espace geographique, 3(3), Paris, pp.189-204.

Brundtland Commission (World Commission on Environment and Development) (1987) Our Common Future. Oxford: Oxford University Press.

Bryman, A. (2007). "The Research Question in Social Research: What is its Role?" International Journal of Social Research Methodology, 10(1), pp. 5-20.

Clark, P.A. (1984). "A challenge: a global definition of community education", International Community Education association Newsletter, Vol.6 (1), pp.7-11.

Claval, P. (1974). "La geographie et la perception de l'espace". L'espace gegraphique, 3(3), Paris, pp. 179-187.

Claval, P. (1981). "Les geographes et les realites culturelles". L'espace geographique, 4, Paris, pp.242-248.

Clover, D. (1995). “Gender, transformative learning and environmental action”, Gender and Education, 7(3), pp. 243-258.

Clover, D. (1996). "Developing international environmental adult education: the challenge, theory and practice”. In L.Filho, Z.Murphy and K.O'Loan (Eds), A sourcebook for environmental 
Education: a practical review based on the Belgrade Charter, the Parthenon Publishing Group, London, pp. 92-111.

Clover, D. (1997). The greening education, UNESCO Sources, No.91, June.

Clover, D.E.; Follen,S. and Hall,B. (1998). The nature of Transformation: Environmental, Adult and Education. Department of Adult Education, Ontario, Canada, Ch.1.

Clover, D.E. (2002). "Traversing the gap: concientizacion, educative-activism in environmental adult education", Environmental Education Research, Vol.8, No.3, pp.315-323.

Crang, M. (2003). "Qualitative methods: touchy, feely, look-see?" Progress in Human Geography, 27(4), 494p.

Dankelman, I. and Davidson, J. (Eds). (1988). Women and environment in the Third World, Alliance for the Future. Earthscan Publications Ltd. In association with The International Union for Conservation of Nature Resources (IUCN), London.

Daly, M. (1978). Gyn/ecology, the metaethics of radical feminism. Boston:Beacon Press.

Decoudras, P. (1997). A la recherche des logiques paysannes. Edition Karthala: Paris, 146p.

Desai, V. and \& Potter, R. (eds), (2002) The Companion to Development Studies. New York: Oxford University Press, 562p.

Dovers, S. (1999). Education for sustainability: repositioning Environmental Education at the Core of Policy through an "Environmental crisis". Unpublished paper presented at " Southern Crossings: Pointers for Change", International Conference of Environmental Education, Sydney, 14-18 January. 
Faessel, S. (1997). "La mer, objet litteraire dans quelques texts du XIXe siecle". In Boyer, P. La mer, espace, perception et imagnaire dans le Pacifique sud. Editions l'Harmattan, Universite Francaise du Pacifique, CORAIL, paris, pp.101-115.

Fien, J. (1999). "Curriculum reform for sustainability in a civil society". Centre for innovation and research in Environmental Education, Griffith University. In Thomas, P and Bessell, S. (Eds), (1999). Education for Sustainable Development: getting it right. Development Studies Network: Canberra, Australia.

Fien, J. and Passingham, S. (2002). "Pacific Star: community theatre as environmental learning in Vanuatu", Australian Journal of Environmental Education, Vol.18, pp.63-70.

Forbes, J. (1987). "Environmental education - Implications for public policy", The Environmentalist, Vol.7, No.2, pp. 131-142.

Fortmann, L. (1997). "Fruits of their labors: Gender, property rights, and tree planting in two Zimbabwe villages". Rural sociology, 62(3), pp. 295-314.

Freire, P. (1972). The pedagogy of the Oppressed. Penguin Books, London.

Frerot, A.M. (1997). Pratiques de gestion dans les pays tropicaux. 6e tournee de geographie tropicale du comite national de geographie, Talence.

Friedberg, C. (1993). "Representation, classification: comment l'homme pense ses rapports au milieu naturel". In Jollivet (Dir), Sciences de la nature. Science de la societe, les passeurs de frontieres. CNRS: Paris. Pp.357-371.

Graham, B.S, and Murphy, E.E. (1999). "Female education and socioeconomic development: A Baha'I perspective", National Centre for Development Studies, The Australian National University. In Thomas, P and Bessell, S. (Eds), (1999). Education for Sustainable Development: getting it right. Development Studies Network: Canberra, Australia. 
Griffin, S. (1978). Women and nature: The roaring inside her. New York: Harper \& Row.

Heilich, J.E. (n.d.). Non-formal environmental education: towards a working definition. ERIC: CSMEE Information Bulletin.

Ho, R.P.K, (1998). "Perception of environmental education amongst primary and secondary teachers in Nairobi, Kenya". Environmental Education and Information, 17(1), pp.71-90.

Jones-Walters, L. (2000). “Communication: The basics". In S. Rientjes (Ed) Communicating Nature Conservation: A Manual for Using Conservation Policy and Action, European Center for nature Conservation, Tilburg, NL, Ch.1.

Jost, C. (1994). "Contraintes et enjeux environnementaux des territories francais du Pacifique sud”. In Le Bourdiec, P., Jost, C. et Angleviel, F. (1994). Geo-Pacifique des espaces francais, texts reunis pour les Journees Geographiques. CTRDP: Noumea, 228p.

Kenyatta, J. (1965). Facing Mount Kenya: The traditional life of the Gikuyu. London: Heinemann.

Lechte, R. (1993). "Women as Educators for Primary Environmental Care". Paper written for the May 1993 Seminar on Environmental Education for women in Asia. Taiwan.

Live and Learn Environmental Education. (2004). Rapid Assessment of Perceptions into environmental education in Maldivian schools, 34p.

Live and Learn Environmental Education. (2006). Live and Learn Environmental Education Report 2006, 18p.

Live and Learn Environmental Education. (2006). Rapid Assessment of community perceptions on environmental issues. Research facilitators guide. Building a Sustainable Future: Education for Sustainable Development in the South Pacific, $17 \mathrm{p}$. 
Live and Learn Environmental Education. (2007). Building a sustainable future. A Rapid Assessment of Perceptions towards environment and sustainability issues in rural Melanesian communities, $51 \mathrm{p}$.

Maser,C.and Kirk, C. (1996). "Local Community Development". In C.Maser, (Ed.) Resolving Environmental Conflict : Towards Sustainable Community Development. St Lucie Press, Florida, Chapter 11, pp.167-200.

McMaster, J. (1999). "Education for sustainable development in Melanesia". Faculty of Management, University of Canberra. In Thomas, P and Bessell, S. (Eds), (1999). Education for Sustainable Development: getting it right. Development Studies Network: Canberra, Australia.

Mies, M. \& Shiva, V. (1993). Ecofeminism. Halifax: Fernwood Publications.

Millennium Ecosystem Assessment. (2005). Ecosystems and Human Well-Being: Biodiversity synthesis. World Resources Institute, Washington.

Moles, A. (1982). "Nissologie ou science des iles”. L'espace geographique (4), pp.281-289.

Moles, A. (1998). "Vers une psycho-geographie". Encyclopedie de geographie (10), pp.177-205.

Nathani, N. (1996). Sustainable development: Indigenous forms of food processing technologies. A Kenyan case study. Unpublished doctoral dissertation: University of Toronto.

Nelson, D. (1999). "Teaching for development in industrial countries: Lessons from experience, UNICEF Australia". In Thomas, P and Bessell, S. (Eds), (1999). Education for Sustainable Development: getting it right. Development Studies Network: Canberra, Australia.

Njiro, E.I. (1999). "Women's empowerment and the anthropology of participatory development". In V.U James \& J.S Etim (eds), The feminization of development processes in Africa (pp.3150). Westport Connecticut: Praeger. 
Orr, D. (1992). Ecological literacy: Education and the Transition to a Postmodern World. State University of New York Press, Albany.

Pachamama. (1995). Numbers 1 and 2, ICAE, Toronto.

Parpat, J. (2002). "Gender and Empowerment: new thoughts, new approaches". In Desai, V. and \& Potter, R. (eds), (2002) The Companion to Development Studies. New York: Oxford University Press, 562p.

Parpat, J., Rai, S. and Staudt, K. (eds) (2002) Rethinking empowerment: Gender and Development in a Global/Local World. London: Routeledge.

Paules, J.P. (2002). Les representations mentales en geographie. Antropos: economica. 152p.

Petilani, W. (1999). "Village sustainability: An educational model for overcoming poverty at the village level - the Papua New Guinea experience." Australian Institute of tropical Architecture, James Cook University. In Thomas, P and Bessell, S. (Eds), (1999). Education for Sustainable Development: getting it right. Development Studies Network: Canberra, Australia.

Perkins, J. J., R. W. Sanson-Fisher, et al. (1995). "The development of a new methodology to assess perceived needs among indigenous Australians." Social Science \& Medicine, 41(2), $267 \mathrm{p}$.

Peron, F. (1993). Des iles et des homes, l'insularite aujourd'hui. Editions de la cite, Editions Ouest - France, Rennes, france, 287p.

Piaget, J. (1947). La representation du monde chez l'enfant. PUF: Paris. 424p.

Rahnema, M. (1992). "Participation". In W. Sachs (Ed), The Development Dictionary. Zed Books: London, pp.116-131. 
Rasmussen, S.J (1998). "Only women know trees: Medecine women and the role of herbal healing in Tuareg culture”. Journal of Anthropological Research, 54(2), pp.147-171.

Redfield, J. (1997). The Celestine vision: Living the new spiritual awareness. New York: A Time Warner Company.

Rodda, A. (1991). Women and the environment. Zed Books Ltd: London.

Rowlands, J. (1997) Questioning empowerment: Working with women in Honduras. Oxford: Oxfam Publications.

Salvat. M. and Pages, M. (1977). Programme de l'UNESCO sur l'homme et la biosphere (MAB). Theme VIII sur les iles: ecologie et utilization rationelle des ecosystemes insulaires: takapoto, Tuamotu, Polynesie francaise, Papeete, MAB, 150p.

Sanguine, A.L. (1997). "Vivre dans une ile, une geopolitique des insularites". Collection Geopolitique et Culture. L'Harmattan: Paris, 389p.

Sauve, L. (1996). "Environmental education and Sustainable Development: A Further Appraisal". Canadian Journal of Environmental Education, 1, pp.7-14.

Scheyvens, R. and Storey, D. (2006). Development fieldwork. A practical guide. SAGE Publications: London. 263p.

Schumacher, E.F. (1999). Small is Beautiful. Economics as if people mattered. Hartley \& Marks. $286 \mathrm{p}$.

Seager, J. (1993). Earth Follies: coming to feminist terms with the global environmental crisis. New York: Routledge. 
Shah, P. (1997). "Farmers as analysts, facilitators and decision- makers". In N.Nelson and S. Wright (Eds), Power and Participatory Development.Intermediate Technology Publications: London, pp.83-94.

Sharp, L. (2002). "Public participation and policy: unpacking connections in one UK Local Agenda 21". Local Environment, Vol.7, No.1, pp.7-22.

Shiva, V. (1993). “Women's indigenous knowledge and biodiversity conservation”. In M . Mies \& V. Shiva (Eds), Ecofeminism (pp.164-173). Halifax, N.S: Fernwood.

Shiva, V. (1988). Staying alive, women, ecology and development. London: Zed Books.

SPREP (1997). Environmental Education teachers manual - Environmental Education issues in the Pacific, DUNNE, M; WENDT, N.M (Eds), Western Samoa, Institute of Education, University of South pacific, Fiji, 156p.

Sontheimer, S. (Ed), (1991). Women and the environment: a reader. London: Earthscan Publications.

Starthy, K. (1995). "Saving the plants that saves lives: SPACEE". Fiji department of Forestry Women and Forest Programme, Convergence, XXVIII (4), pp. 71-80.

Tait, E. (1999). "Future options, UNESCO Office for the Pacific States, Samoa". In Thomas, P and Bessell, S. (Eds), (1999). Education for Sustainable Development: getting it right. Development Studies Network: Canberra, Australia.

The New Straits Times Press . (2007). The truth about palm oil, article was published Thursday, 27 September 2007.

UNCED. (1992). Agenda 21, Geneva, UNCED. 
Van Trease, H. (1987). The politics of land in Vanuatu, from colony to independence. Institute of Pacific Studies of the University of the South Pacific, Fiji, 265p.

Wahab, H. (1999). “Can short term training be sustainable?" In Thomas, P and Bessell, S. (Eds), (1999). Education for Sustainable Development: getting it right. Development Studies Network: Canberra, Australia.

Wane, N. (2000). "Indigenous knowledge: Lesson from the elders: A Kenyan case study". In G. Dei, B. hall, \& D. Rosenberg (Eds), Indigenous knowledges in global contexts: Multiple readings of our world (pp.38-53). Toronto: University of Toronto Press.

Wane, N. (2002). "African women and spirituality: Connections between thought and education". In E.V.O'Sullivan, A. Morrell, \& M.O'Connor (Eds), Expanding the boundaries of transformative learning: Essays on theory and praxis (pp.135-150), New York: Palgrave.

Wane, N and Chandler, D.J. (2002). "African women, cultural knowledge, and environmental education with a focus on Kenya's indigenous women". Canadian Journal of Environmental Education, Vol.7, No.1, pp.86-98.

Warren, K.J. (Ed). (1994). Ecological feminism. New York: Routledge.

Weaver, S., Gavin, M., Warrick, O., \& Leathers, A. (2007). Socio-Economic Good Practise Guidance for Reducing Emissions from Deforestation in Developing Countries. Victoria University of Wellington (forthcoming).

Weightman, B. (1989). Agriculture in Vanuatu: A historical review British Friends of Vanuatu Great Britain, p.252.

Whyte, J., S. Siwatibau, A. Tapisuwe, J. Kalotap, and T. Fraser. (1998). Participatory resource management in Vanuatu: research report, FSPI, Port Vila. 
Williams, A and Grace, T. (1999). "An elephant has to carry its tusks: Grandparents' efforts to educate their grandchildren in rural Uganda”. Tropical Health Programme, Australian Centre for International and Tropical health and Nutrition, Medical Research Council (UK) Programme on AIDS in Uganda. In Thomas, P and Bessell, S. (Eds), (1999). Education for Sustainable Development: getting it right. Development Studies Network: Canberra, Australia.

Willis, R. (1981). A state in the making. Myth, History and Social Transformation in the Precolonial Ufipa. Indiana University Press: Bloomington, IN.

Wyman, M. (Ed). (1999). Sweeping the Earth: women taking action for a healthy planet. Charlotte-town: PEI, Gynergy Books.

Young, E. (1999). "Implementing sustainable development: A challenge in education for the future". Graduate Studies in Environmental Management and Development, National Center for Development Studies, The Australian University. In Thomas, P and Bessell, S. (Eds), (1999). Education for Sustainable Development: getting it right. Development Studies Network: Canberra, Australia. 


\section{Internet sources:}

- United Nations Millennium Project:

(www.unmillenniumproject.org/reports/tf_environment.htm)

- United Nations Development Program

www.undp.org

http://www.undp.org/mdg

- United Nations Environmental Program

www.unep.org

- United Nations

www.unicef.org

- United Nations Millennium Campaign:

http://endpoverty2015.org/goals/environmental-sustainability

- Millenium Ecosystem Assessment:

http://www.millenniumassessment.org/documents/document.354.aspx.pdf

- CCB Standards

http://www.climate-standards.org/index.html

- Wikipedia Encyclopedia:

http://en.wikipedia.org/wiki/Development_geography

http://en.wikipedia.org/wiki/Economic_development

http://en.wikipedia.org/wiki/Empowerment

www.wikipedia.org/wiki/Flag of Vanuatu 